Chemistry Division Chemistry Division Chemistry Division Chemistry Division Cheinistry Division Chemistry Division

\section{Radiolytic Generation of Gases from Synthetic Waste \\ Annual Report - FY 1991}

\author{
by D. Meisel, H. Diamond, \\ E. P. Horwitz, C. D. Jonah, \\ M. S. Matheson, M. C. Sauer, Jr., \\ J. C. Sullivan, F. Barnabas, \\ E. Cerny, and Y. D. Cheng
}


Argonne National Laboratory, with facilities in the states of Illinois and Idaho, is owned by the United States government, and operated by The University of Chicago under the provisions of a contract with the Department of Energy.

\section{DISCLAIMER}

This report was prepared as an account of work sponsored by an agency of the United States Government. Neither the United States Government nor any agency thereof, nor any of their employees, makes any warranty, express or implied, or assumes any legal liability or responsibility for the accuracy, completeness, or usefulness of any information, apparatus, product, or process disclosed, or represents that its use would not infringe privately owned rights. Reference herein to any specific commercial product, process, or service by trade name, trademark, manufacturer, or otherwise, does not necessarily constitute or imply its endorsement, recommendation, or favoring by the United States Government or any agency thereof. The views and opinions of authors expressed herein do not necessarily state or reflect those of the United States Government or any agency thereof.

Reproduced from the best available copy.

Available to DOE and DOE contractors from the

Office of Scientific and Technical Information

P.O. Box 62

Oak Ridge, TN 37831

Pr; is available from (61.5) 576-8401, FTS 626-8401

Available to the public from the

National Technical Information Service

U.S. Department of Commerce

5285 Port Royal Road

Springfield, VA 22161 
Distribution Category: UC-600

$\overline{\text { ANL-91/41 }}$

ANL- $-91 / 41$

DE92 007138

\section{ARGONNE NATIONAL LABORATORY \\ 9700 South Cass Avenue \\ Argonne, Illinois 60439}

\section{RADIOLYTIC GENERATION OF GASES FROM SYNTHETIC WASTE \\ ANNUAL REPORT - FY 1991}

by

D. Meisel, H. Diamond, E. P. Horwitz, C. D. Jonah, M. S. Matheson, M. C. Sauer, Jr., J. C. Sullivan,

F. Barnabas, E. Cerny, and Y. D. Cheng

Chemistry Division

December 1991

Work performed for Westinghouse Hanford Company in accordance with P.O. M652408.

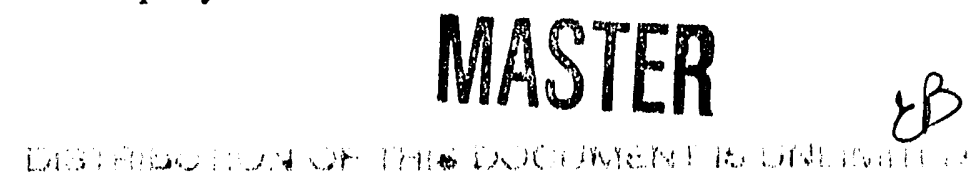




\section{TABLE OF CONTENTS}

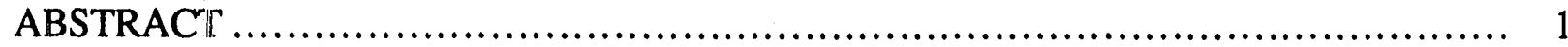

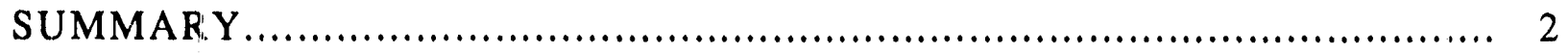

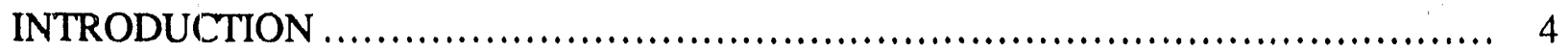

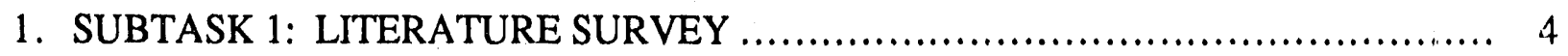

2. SUBTASK 2: MEASUREMENT OF RADIOL YTIC YIELDS $\ldots \ldots \ldots \ldots \ldots \ldots \ldots \ldots \ldots, 5$

2a. Experimental ............................................................. 5

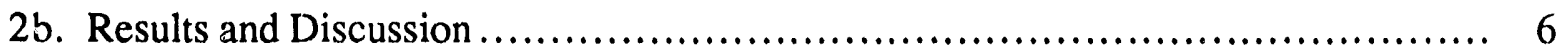

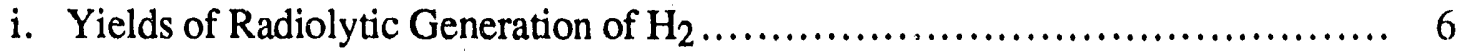

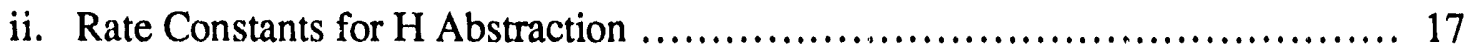

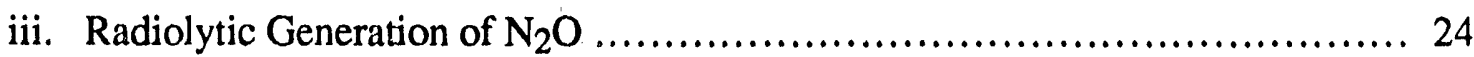

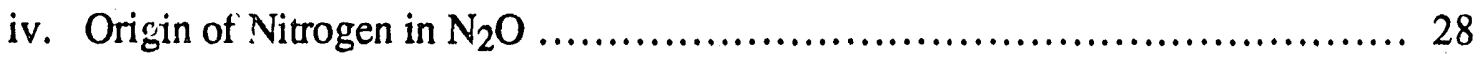

v. Radiolytic Generation of Other Gases .................................... 29

vi. Thermal Generation of Gases ............................................ 30

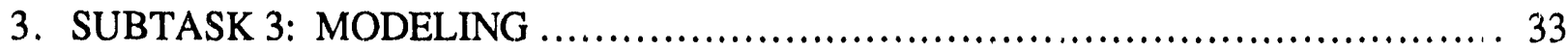

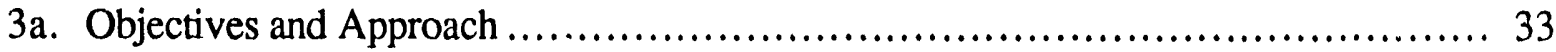

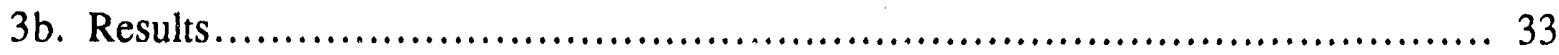

i. Hydrogen-Production Mechanisms and Yields ............................ 33

ii. Hydrogen Peroxide Yields ............................................ 39

iii. $\mathrm{N}_{2} \mathrm{O}$ Production Mechanisms ........................................... 39.

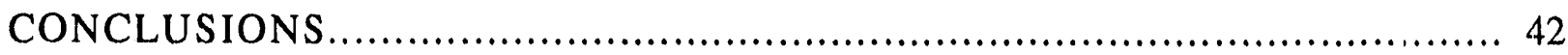

APPENDIX A: EXPERIMENTAL TECHNIQUES $\quad \ldots \ldots \ldots \ldots \ldots \ldots \ldots \ldots \ldots \ldots \ldots \ldots . . \ldots . \ldots . \ldots 4$

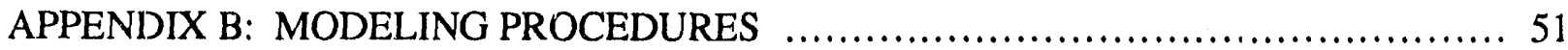

APPENDIX C: COMPARISON OF RADIATION SOURCES $\ldots \ldots \ldots \ldots \ldots \ldots \ldots \ldots \ldots \ldots$

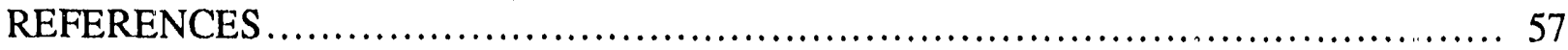




\section{LIST OF FIGURES}

No.

1. Concentration of $\mathrm{H}_{2}$ in millimoles per liter of solution vs. dose for Solution $\mathrm{P}$ at a dose rate of $0.41 \mathrm{krad} / \mathrm{min}$

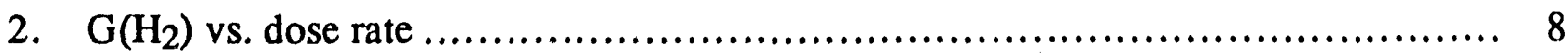

3. $\mathrm{G}\left(\mathrm{H}_{2}\right)$ vs. dose rate for Solution $\mathrm{P}$ with $0.085 \mathrm{M}$ EDTA, irradiated at $30^{\circ} \mathrm{C} \ldots \ldots \ldots . .8$

4. $\mathrm{G}\left(\mathrm{H}_{2}\right)$ vs. dose rate for Solution $\mathrm{P}$ with $0.085 \mathrm{M}$ HEDTA, irradiated at $30^{\circ} \mathrm{C} \ldots \ldots \ldots . .9$

5. $\mathrm{G}\left(\mathrm{H}_{2}\right)$ vs. dose rate for Solution $\mathrm{P}$ with $0.085 \mathrm{M}$ each of EDTA and HEDTA, irradiated at $30^{\circ} \mathrm{C}$

6. $\mathrm{G}\left(\mathrm{H}_{2}\right)$ vs. dose rate for Solution $\mathrm{P}$ with $0.34 \mathrm{M}$ IDA, irradiated at $30^{\circ} \mathrm{C} \ldots \ldots \ldots \ldots \ldots 10$

7. $\mathrm{G}\left(\mathrm{H}_{2}\right)$ vs. dose rate for Solution $P$ with $0.17 \mathrm{M}$ citrate, irradiated at $30^{\circ} \mathrm{C} \ldots \ldots \ldots \ldots . .10$

8. $\mathrm{G}\left(\mathrm{H}_{2}\right)$ vs. [EDTA] in Solution $\mathrm{P}$ irradiated at $4.4 \mathrm{krad} / \mathrm{min}$ to $130 \mathrm{krad}$ dose at $30^{\circ} \mathrm{C}$. 11

9. $\mathrm{G}\left(\mathrm{H}_{2}\right)$ vs. [HEDTA] in Solution $\mathrm{P}$ irradiated at $4.4 \mathrm{krad} / \mathrm{min}$ to $130 \mathrm{krad}$ dose at $30^{\circ} \mathrm{C}$.

10. $\mathrm{G}\left(\mathrm{H}_{2}\right)$ vs. [EDTA] and [HEDTA] in Solution $\mathrm{P}$ irradiated at $4.4 \mathrm{krad} / \mathrm{min}$ to $130 \mathrm{krad}$ at $30^{\circ} \mathrm{C}$.

11. $\mathrm{G}\left(\mathrm{H}_{2}\right)$ vs. [IDA] in Solution $\mathrm{P}$ irradiated at 4.4 and $17 \mathrm{krad} / \mathrm{min}$ to $130 \mathrm{krad}$ dose at $30^{\circ} \mathrm{C}$.

12. $\mathrm{G}\left(\mathrm{H}_{2}\right)$ vs. [citrate] in Solution $P$ irradiated at $4.4 \mathrm{krad} / \mathrm{min}$ to $130 \mathrm{krad}$ dose at $30^{\circ} \mathrm{C}$. 13

13. $\mathrm{G}\left(\mathrm{H}_{2}\right)$ vs. [EDTA] in Solution $P$ irradiated at $60{ }^{\circ} \mathrm{C}$ at $4.7 \mathrm{krad} / \mathrm{min}$ to $150 \mathrm{krad}$ (except for three samples at $0.085 \mathrm{M}$ that received $560 \mathrm{krad}$ )

14. The dependence of the efficiency of $\mathrm{H}_{2}$ generation (in $\mathrm{G}$ values per mole) of the various organic solutes on the hydrogen content of the compound.

15. $\mathrm{G}\left(\mathrm{H}_{2}\right)$ at $30^{\circ} \mathrm{C}$ vs. [EDTA] in aqueous $0.1 \mathrm{M} \mathrm{NaOH}, 1 \mathrm{M} \mathrm{NaCl}, 1.0 \mathrm{mM} \mathrm{NaNO} 3$ solution

16. $\mathrm{G}\left(\mathrm{H}_{2}\right)$ at $30^{\circ} \mathrm{C}$ vs. [HEDTA] in aqueous $0.1 \mathrm{M} \mathrm{NaOH}, 1 \mathrm{M} \mathrm{NaCl}, 1.0 \mathrm{mM} \mathrm{NaNO}_{3}$ solution

17. $\mathrm{G}\left(\mathrm{H}_{2}\right)$ at $30^{\circ} \mathrm{C}$ vs. [NTA] in aqueous $0.1 \mathrm{M} \mathrm{NaOH}, 1 \mathrm{M} \mathrm{NaCl}, 1.0 \mathrm{mM} \mathrm{NaNO}_{3}$ solution

18. $\mathrm{G}\left(\mathrm{H}_{2}\right)$ at $30^{\circ} \mathrm{C}$ vs. [IDA] in aqueous $0.1 \mathrm{M} \mathrm{NaOH}, 1 \mathrm{M} \mathrm{NaCl}, 1.0 \mathrm{mM} \mathrm{NaNO}$ solution 
No.

\section{LIST OF FIGURFS (Cont'd)}

19. $\mathrm{G}\left(\mathrm{H}_{2}\right)$ at $30^{\circ} \mathrm{C}$ vs. [citrate] in aqueous $0.1 \mathrm{M} \mathrm{NaOH}, 1 \mathrm{M} \mathrm{NaCl}, 1.0 \mathrm{mM} \mathrm{NaNO}_{3}$ solution

20. $\mathrm{G}\left(\mathrm{H}_{2}\right)$ at $60^{\circ} \mathrm{C}$ vs. [EDTA] in aqueous $0.1 \mathrm{M} \mathrm{NaOH}, 1 \mathrm{M} \mathrm{NaCl}, 1.0 \mathrm{mM} \mathrm{NaNO}_{3}$ solution

21. $\mathrm{G}\left(\mathrm{H}_{2}\right)$ at $60^{\circ} \mathrm{C}$ vs. [HEDTA] in aqueous $0.1 \mathrm{M} \mathrm{NaOH}, 1 \mathrm{M} \mathrm{NaCl}, 1.0 \mathrm{mM} \mathrm{NaNO} 3$ solution

22. $\mathrm{G}\left(\mathrm{H}_{2}\right)$ at $60^{\circ} \mathrm{C}$ vs. [NTA] in aqueous $0.1 \mathrm{M} \mathrm{NaOH}, 1 \mathrm{M} \mathrm{NaCl}, 1.0 \mathrm{mM} \mathrm{NaNO}$ solution

23. $\mathrm{G}\left(\mathrm{H}_{2}\right)$ at $60^{\circ} \mathrm{C}$ vs. [IDA] in aqueous $0.1 \mathrm{M} \mathrm{NaOH}, 1 \mathrm{M} \mathrm{NaCl}, 1.0 \mathrm{mM} \mathrm{NaNO}$ solution

24. $\mathrm{G}\left(\mathrm{H}_{2}\right)$ at $60^{\circ} \mathrm{C}$ vs. [citrate] in aqueous $0.1 \mathrm{M} \mathrm{NaOH}, 1 \mathrm{M} \mathrm{NaCl}, 1.0 \mathrm{mM} \mathrm{NaNO}$ solution

25. The correlation between the empirical parameter $\mathrm{R}$ and the rate constant $\mathrm{k}$ for $\mathrm{H}$ abstraction 25

26. Postirradiation production of $\mathrm{N}_{2} \mathrm{O}$ in $0.17 \mathrm{M}$ IDA in Solution $\mathrm{P}$, at $30^{\circ} \mathrm{C}$ 27

27. $\mathrm{G}\left(\mathrm{O}_{2}\right)$ vs. dose rate for Solution $\mathrm{P}$

28. Thermal production of $\mathrm{H}_{2}$ at $60^{\circ} \mathrm{C}$ from several solutions. 31

29. Production of $\mathrm{N}_{2} \mathrm{O}$ at $60^{\circ} \mathrm{C}$ from Solutions $\mathrm{POI}$ and $\mathrm{POC}$ 32

30. Calculated yield of $\mathrm{H}_{2}$ as a function of the rate of the hydrogen abstraction reaction (expressed as $\mathrm{k} \times[\mathrm{RH}]$ in units of $\mathrm{s}^{-1}$ ).

31. Calculated effect of nitrite and nitrate on the yield of $\mathrm{H}_{2}$

32. Computed yield of radiolytically generated $\mathrm{H}_{2}$ as a function of the rate of the $\mathrm{H}$-abstraction reaction

33. Yield of $\mathrm{H}_{2}$ as a function of revised rate for the $\mathrm{H}$-atom abstraction reaction from the organic solute

34. Calculated dependence of $\mathrm{H}_{2} \mathrm{O}_{2}$ yis:lds on the reaction rate of organic solutes with $\mathrm{OH}$ radicals (top) for two model parameters and on nitrate and nitrite concentration (bottom)

35. Changes in the nitrate and nitrite concentration (top) and accumulation of intermediates (bottom) as a result of radiolysis $(0.025 \mathrm{krad} / \mathrm{min}$; assurned in 101-SY).. 41 


\section{LIST OF FIGURES (Cont'd)}

A-1. Van Slyke apparatus for extraction of gases from irradiated solutions................ 46

A-2. Infotronics gas chromatograph: front panel................................................. 47

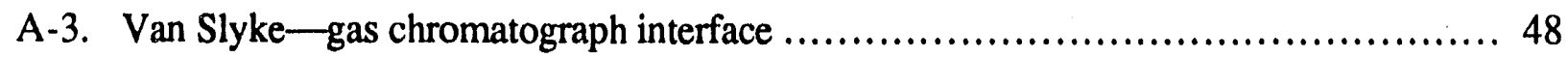

A-4. Multisource irradiation chamber ............................................... 49

A-5. Samples set up for multisource chamber................................................. 50

B-1. Calculated time dependence of the disappearance of $\mathrm{H}$ atoms and generation of $\mathrm{H}_{2} \ldots . .52$ 
No.

\section{LIST OF TABLES}

1. Relative efficiencies for $\mathrm{H}_{2}$ production from radiolysis of Solution $\mathrm{P} \ldots \ldots \ldots \ldots \ldots \ldots \ldots 15$

2. Experimental results for $\mathrm{G}\left(\mathrm{H}_{2}\right)$ at $60^{\circ} \mathrm{C}$ and comparison with results at $30^{\circ} \mathrm{C} \ldots \ldots \ldots . .16$

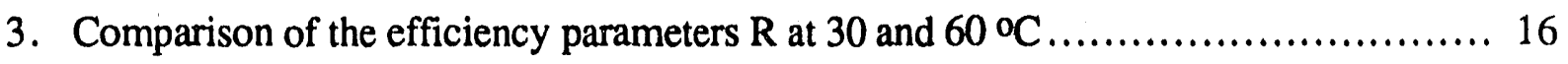

4. The effect of $\mathrm{Na}_{2} \mathrm{~S}$ on the yield of $\mathrm{H}_{2}$ in Solution $\mathrm{P}$ with $0.17 \mathrm{M}$ EDTA $\ldots \ldots \ldots \ldots \ldots \ldots 17$

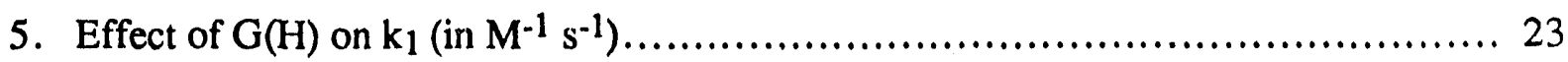

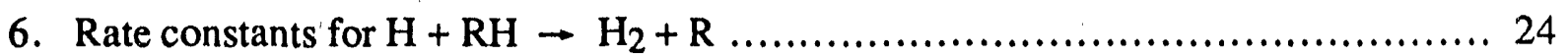

7. $\mathrm{G}\left(\mathrm{N}_{2} \mathrm{O}\right)$ for Solution $\mathrm{P}$ with the organic solutes under various conditions............. 26

8. Comparison of $\mathrm{G}\left(\mathrm{N}_{2} \mathrm{O}\right)$ from irradiation at 30 and $60{ }^{\circ} \mathrm{C}$ of Solution $\mathrm{P}$ containing various additives............................................................. 28

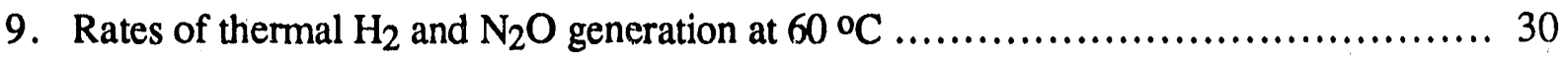

B-1. Diffusion-model parameters used in the calculations of yields...................... 53

B-2. Rate constants used in the calculations of radiation chemical yieids.................. 53

B-3. Reactions and rate constants used in the simulation of homogeneous kinetics for the

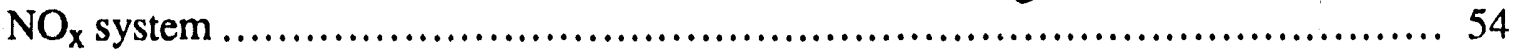

C-1. Conversion table for radiation sources in tank 101-SY (from $\frac{\mu \mathrm{Ci}}{1}$ to $\frac{\mathrm{krad}}{\min }$ )........... 56 


\title{
RADIOLYTIC GENERATION OF GASES FROM SYNTHETIC WASTE
}

ANNUAL REPORT - FY 1991

by

D. Meisel, H. Diamond, E. P. Horwitz, C. D. Jonah, M. S. Matheson, M. C. Sauer, Jr., J. C. Sullivan, F. Barnabas, E. Cerny, and Y. D. Cheng

\begin{abstract}
Yields of $\mathrm{H}_{2}, \mathrm{~N}_{2} \mathrm{O}, \mathrm{O}_{2}$, and $\mathrm{N}_{2}$, in simulated waste solutions, containing high nitrate, nitrite, hydroxide and aluminate, were experimentally measured in the presence and absence of moderate concentrations of organic chelators and sorne of their degradation products. These yields were measured at 30 and $60^{\circ} \mathrm{C}$. No effect of dose rate on yield of $\mathrm{H}_{2}$ was observed and the amount of $\mathrm{H}_{2}$ increases linearly with dose and with the concentration of the organic additive. The generation of $\mathrm{N}_{2} \mathrm{O}$ was observed only when organic solutes were present and its yield was dose rate dependent. Rate constants for $\mathrm{H}$ atom abstraction from the organic component by free $\mathrm{H}$ atoms were determined and these were correlated with the efficiency of the organic solute in the generation of $\mathrm{H}_{2}$. The rate of thermal generation of $\mathrm{H}_{2}$ and $\mathrm{N}_{2} \mathrm{O}$ was also measured and was found to substantially increase in solutions that were preirradiated, presumably due to the generation of radiolytic degradation products. Computer modeling of the radiolytic precesses show the yield of $\mathrm{H}_{2}$ is strongly dependent on the nitrite concentration; the yield decreases with increasing nitrite concentration. The yield will be only weakly dependent on nitrate concentration above $0.5 \mathrm{M}$. Simulation of the homogeneous reactions that describe the chemistry of the $\mathrm{NO}_{\mathrm{x}}$ system indicate that: no $\mathrm{N}_{2} \mathrm{O}$ will be formed in the absence of $\mathrm{NO}_{\mathrm{x}}$-organic reactions.
\end{abstract}




\section{SUMMARY}

A study of the Radiolytic Generation of Gases from Synthetic Waste was initiated in mid January 1991. This report summarizes activities during FY 1991. The study was carried out in three parallel directions. A literature survey on the radiolytic generation of gases was conducted under Subtask 1. Yields of $\mathrm{H}_{2}, \mathrm{~N}_{2} \mathrm{O}, \mathrm{O}_{2}$, and $\mathrm{N}_{2}$ in simulated waste solutions were experimentally measured under Subtask 2. Thermal generation of these gases was also measured in some cases. A computer simulatic in code of predictive capabilities that provides information on the effect of the variations of physical parameters and chemical composition on the radiolytic generation of the gases, was developed and implemented under Subtask 3. Of prime concern to this study were the gases generated in tank 101-SY. Only homogeneous solutions of compositions similar to those existing in the waste tanks were studied during FY 1991. The study of heterogeneous slurries will commence in FY 1992.

Highlighted in the following are the accomplishments and conclusions attained during F Y 1991:

Subtask 1: A comprehensive and critical literature survey has been conducted. The results and conclusions of this survey have been submitted to WHC as a separate report. ${ }^{1}$

Subtask 2:

a. The radiolytic yields of $\mathrm{H}_{2}$ and $\mathrm{N}_{2} \mathrm{O}$ from solutions simulating the homogeneous phase of the waste in tank 101-SY have been measured at 30 and $60^{\circ} \mathrm{C}$. The effects of dose, dose rate, and concentration of organic solutes and other additives on these yields have been determined. For $\mathrm{H}_{2}$, the yield measurements combined with measurements made of the rate constants for reaction of $\mathrm{H}$ atoms with organic solutes allow an accurate chemical mechanism to be stated. Although for $\mathrm{N}_{2} \mathrm{O}$, our understanding is primarily phenornenological, empirical information bearing on the detailed mechanism has been obtained. Organic solutes are essential for the production of $\mathrm{N}_{2} \mathrm{O}$ but their identity and concentration have little effect on the radiolytic yield of $\mathrm{N}_{2} \mathrm{O}$.

b. The yields of $\mathrm{H}_{2}$ and $\mathrm{N}_{2} \mathrm{O}$ from thermal processes in the simulated waste solutions have been measured at $60^{\circ} \mathrm{C}$. The thermal yields are small (relative to the yields at the dose rates used in this study) unless the solution has been irradiated. Irradiation (equivalent to approximately 2.5 years in tank 101-SY) is shown to greatly increase the thermal yields, presumabiy due to the formation of radiolytic degradation products.

c. The yields of several other gaseous products were also determined. Although $\mathrm{O}_{2}$ is produced, it is consumed in the presence of organic solutes, probably by reaction with radiolytically produced organic radicals. Under some conditions, a small yield of $\mathrm{N}_{2}$ was observed.

Subtask 3: Computer modeling of the nonhomogeneous deposition of energy and the reactions that ensue in the highly concentrated nitrate and nitrite basic aqueous solution shows:

a. The yield of $\mathrm{H}_{2}$ formed is strongly dependent on the nitrite concentration; the yield decreases with increasing nitrite concentration. As a corollary, if the nitrite concentration is at least $2.0 \mathrm{M}$ (which is necessary to minimize $\mathrm{H}_{2}$ yields), no additive that may decrease $\mathrm{H}_{2}$ yields by reacting with the $\mathrm{H}$ atom will make any substantive effect. The yield will be virtually independent of nitrate concentration as long as the nitrate concentration is greater than $0.5 \mathrm{M}$. The yield of $\mathrm{H}_{2}$ depends strongly on the concentration of organic additives and their reactivity (rate constants) towards hydrogen abstraction by a $\mathrm{H}$ atom. All of these conclusions are independent of the details of the model used to describe the energy deposition.

b. Calculated hydrogen peroxide yields are more dependent on the details of the model used. The yields of $\mathrm{H}_{2} \mathrm{O}_{2}$ are similar to those of $\mathrm{H}_{2}$; they will decrease upon increasing nitrite concentration and/or concentration of organic solutes.

Simulation of the homogeneous reactions that describe the chemistry of the $\mathrm{NO}_{\mathrm{x}}$ system indicate that: 
c. $\mathrm{No}_{2} \mathrm{O}$ will be formed in the absence of NOx-organic reactions. None was observed experimentally. The steady state concentrations of $\mathrm{NO}, \mathrm{NO}_{2}$, and the other NOx intermediates are very low. Little substantive interconversion in nitrate/nitrite concentrations $(\leq 0.1 \mathrm{M}$ over a 10 year period) can be expected.

Because the secondary chemistry (mostly thermal) of the $\mathrm{NO}_{\mathrm{x}}$-intermediates/organic-solute combinations is poorly understood, no quantitative estimates could be offered on $\mathrm{N}_{2} \mathrm{O}$ generation in the presence of the organic additive. 


\section{INTRODUCTION}

Some of the mixed radioactive wastes in temporary storage tanks at the Hanford site in Richland, Washington have been found to generate mixtures of gases (primarily $\mathrm{H}_{2}$ and $\mathrm{N}_{2} \mathrm{O}$ ). Of particular concern is tank 241-SY-101, where potentially flammable mixtures of $\mathrm{H}_{2}$ and $\mathrm{N}_{2} \mathrm{O}$ are teleased periodically. 2,3 The reports cited show that these gases are generated radiolytically or thermally if certain organics are present. The Chemistry Division at Argonne, with its long history in radiation chemistry, was requested to determine the role of radiation in the production of $\mathrm{H}_{2}$ and other gases in the waste tanks. With sufficieat information, one could then propose remediation strategies that would substantially decrease the buildup of hazardous gas mixtures. Utilizing the information available we began a threefold attack on the problem of the radiolytic genera:tun of gases in homogeneous aqueous solutions similar in composition to the waste in tank 101-SY: $\mathrm{NaOH}, \mathrm{NaNO}_{3}, \mathrm{NaNO}_{2}, \mathrm{NaAlO}_{2}$, organic romplexants (EDTA, HEDTA, NTA, citrate, etc.). Subtask 1 involved a critical literature survey to provide information useful to the technical personnel maintaining the tanks, and to guide our own experiments. The literature survey has been subrnitted separately as a detailed report to Westinghouse Hanford Company. ${ }^{1}$ Our second subtask involved measurement in a solution similar to that in the convecting layer in 101-SY of the yields of $\mathrm{H}_{2}$ and $\mathrm{N}_{2} \mathrm{O}$ at 30 and $60^{\circ} \mathrm{C}$. The latter temperature is similar to the highest temperature attained in the slurry in 101-SY. In the third subtask, computer modeling was used to simulate the nonhomogeneous deposition of energy and ensuing reactions in the highly concentrated nitrate and nitrite basic solutions. The literature survey and computer modeling have been used to guide and interpret our experimental program. Progress to date is outlined in this Report.

\section{SUBTASK 1: LITERATURE SURVEY}

Only the major conclusions of this subtask will be summarized here. A detailed report on this effort has been submitted to WHC. ${ }^{1}$

a. Nonhomogeneous kinetics should be used in analyzing the primary radiolytic reactions in a homugeneous liquid phase. This has been implemented in the computational efforts of Subtask 3 .

b. The vast majority of the species produced radiolytically will convert to their basic forms. The major scavenger for $e_{\mathrm{aq}}^{-}$and its precursors is $\mathrm{NO}_{3}^{-}$, whereas for $\mathrm{H}$ and $\mathrm{OH}\left(\mathrm{O}^{-}\right)$it is $\mathrm{NO}_{2}^{-}$.

c. $\mathrm{O}_{2}$ will be produced by the direct effect of the radiation on nitrate and nitrite. The organic content cannot prevent $\mathrm{O}_{2}$ formation by this pathway, but the presence of organic molecules may lead to the destruction of oxygen via organic radical reactions with $\mathrm{O}_{2}$ in later steps. This has been observed experimentally by Subtask 2 .

d. Much information is available on the yields of $\mathrm{H}_{2}, \mathrm{O}_{2}$, and other products it. nitrate solutions in acidic and near-neutral pH ranges. Less work has been done on nitrite systems and very little on mixtures of nitrate and nitrite. High-nitrate and -nitrite concentrations lead to lower $\mathrm{H}_{2}$ yields and higher $\mathrm{O}_{2}$ yields; higher organic content always leads to higher $\mathrm{H}_{2}$ yields.

e. Aside from the production of $\mathrm{H}_{2}$ by fragmentation of water directly to molecular $\mathrm{H}_{2}$, the most likely radiolytic pathway for the production of $\mathrm{H}_{2}$ is via hydrogen abstraction by hydrogen atoms from organic substrates. Nitrate is so extremely efficient in scavenging $e_{a q}^{-}$, and its precursors, that at concentrations of $>0.5 \mathrm{M}$ it will completely prevent $\mathrm{H}_{2}$ production from $\mathrm{e}_{\mathrm{aq}}^{-}$sources. Nitrite, even though it is an efficient $\mathrm{H}$-atom scavenger, is not so dominating. Other $\mathrm{H}$-atom scavengers (organic compounds) may efficiently compete with nitrite.

f. Although an extensive data base is available on the reactivity of the primary products of water radiolysis, little is known about the reactivity of secondary radicals, in particular of the $\mathrm{NO}_{\mathrm{x}}$ system, with organic substrates.

g. The effects of temperature, pressure, viscosity, and high ionic strength on the radiolytic yields of products and reactivity of the primary radicals are reasonably well understood. None of 
these factors are expected to appreciably affect the reactivity or yields. The effects of temperature on the reactivity of hydrogen atoms and of the secondary radicals are not known. The most relevant of these parameters have been measured by Subtask 2.

$\mathrm{h}$. Some consideration has been given to the use of chemical scavengers as a remediation strategy in light of the information available in the literature. Nitrite is undoubtedly the most promising scavenger, its concentration should be maintained at the $>2 \mathrm{M}$ level to minimize $\mathrm{H}_{2}$ generation.

\section{SUBTASK 2: MEASUREMENTS OF RADIOLYTIC YIELDS}

\section{2a. Experimental}

A solution was prepared that contained approximately $75 \%$ of the major inorganic components originally fed into tank 101-SY. This is referred to here as "Solution P", ana contains $2.27 \mathrm{M}$ $\mathrm{NaOH}, 0.86 \mathrm{M} \mathrm{NaAlO}_{2}$ (note that these concentrations have been corrected relative to those quoted in our previous reports. The correction is based on an analysis of the commercial $\mathrm{NaAlO}_{2}$, which showed 0.17 moles of $\mathrm{NaOH}$ and 1.94 moles of $\mathrm{H}_{2} \mathrm{O}$ per mole of the commercial $\mathrm{NaAlO}_{2}$ ), 2.22 $\mathrm{M} \mathrm{NaNO}$ 2, ard $2.79 \mathrm{M} \mathrm{NaNO}_{3}$. Solution $\mathrm{P}$ was prepared in one-liter amounts as follows: Solid $\mathrm{NaOH}, \mathrm{NaAlO}_{2}$, and $\mathrm{NaNO}_{3}$ were put in a beaker with $600 \mathrm{ml}$ of water and heated with stirring to abnut $90^{\circ} \mathrm{C}$ to dissolve the solids. Solid $\mathrm{NaNO}_{2}$ was put in another beaker with about $100 \mathrm{ml}$ of water and stirred; it did not completcly dissolve, but the contents were completely transferred to the the first beaker by rinsing with water. The contents were heated at about $90^{\circ} \mathrm{C}$ with stirring until the solids dissolved. The solution was then diluted with water to one liter in a volumetric flask. Some batches from this procedure resulted in an orange-colored suspension. The solutions were then filtered through Whatman " $2 \mathrm{~V}$ " paper, regardless of whether a precipitate was observed. Filtered and unfiltered samples gave $\mathrm{H}_{2}$ and $\mathrm{N}_{2} \mathrm{O}$ yields that were the same within experimental accuracy.

Appropriate amounts of the organic solutes* (in the form of their sodium salts) were dissolved by stirring at room temperature with the required amount of Solution $P$ in a volumetric flask. In the case of the sodium salt of HEDTA, the amount of water of hydration had to be determined to accurately make up the solution to tie required molarity. The analysis indicated three water molecules of hydration per Na3HEDTA.

Solutions were degassed by bubbling argon through $10 \mathrm{ml}$ samples contained in $20 \mathrm{ml}$ glass syringes. For samples prepared and irradiated at ambient temperature, the syringes were in an upright position with the argon admitted through the tip at the bottom. For samples to be irradiated at $60^{\circ} \mathrm{C}$, the syringes were placed in an inverted position in a bath at $60^{\circ} \mathrm{C}$ and the argon was introduced by threading a thin Teflon tube through the tip of the syringe and into the solution. After bubbling with argon, the gas (Ar) in the head space was expelled and the syringe was capped for both ambient and elevated temperature experiments. For determination of the thermal production of gaseous products, the syringe was allowed to stand in the $60^{\circ} \mathrm{C}$ bath for the desired time.

The samples were irradiated by placing the syringes in a rack that could reproducibly be positioned relative to a ${ }^{60} \mathrm{Co}$ source. Details of the irradiation sources and the procedures used to determine the yields are given in Appendix A. For the $60^{\circ} \mathrm{C}$ runs, the rack was in a thermostated bath. The dose rates (i.e., radiation intensities, given in this report in $\mathrm{krad} / \mathrm{min}$ ) for several positions of the rack were determined using Fricke dosimetry. ${ }^{4}$ The dosimetry solution was contained in syringes identical to those containing the samples, but the bath was kept at the ambient temperature

*The following abbreviations are used for the indicated compounds: EDTA = ethylenediaminetetraac rate; HEDTA = $\mathrm{N}$-(2-hydroxyethyl)-ethylenediaminetriacetate acid; NTA = nitrilotriacetate acid; IDA = iminodiacetate. 
$\left(30^{\circ} \mathrm{C}\right)$ of the source room. Appropriate corrcutions for density and electron density were made in calculating the dose absorbed by the samples. ${ }^{\dagger}$

The gases produced in the samples were extracted using a Van Slyke apparatus that was modified to allow the extracted gases to bu introduced directly to a gas chromatograph. (A Van Slyke apparatus allows solutions to be taken from the irradiated syringes and manipulated by means of a movable volume of mercury. These procedures can be performed with negligible leakage of air into the apparatus. For details see Appendix A.) The extraction was accomplished by equilibration of the irradiated solution with a gas volume followed by forcing the gas, using a column of mercury, into a smaller volume that could be connected to the stream of the gas chromatograph. This extraction procedure leaves some of the gas in the solution. The fraction remaining in the solution after one extraction was determined experimentally and an appropriate correction was made; for $\mathrm{N}_{2} \mathrm{O}$, the correction factor is $1.038 ;$ for $\mathrm{H}_{2}, \mathrm{O}_{2}$, and $\mathrm{N}_{2}$ the correction factor was negligible $(<1.005)$. The sensitivity of the gas chromatograph was determined by injecting known quantities of the various gases of interest. All gas analyses were done with the syringes and the gases equilibrated at ambient temperature. A "molecular sieve $13 x^{\prime \prime}$ column was used for most of the analyses. When the column was kept at ambient temperature, $\mathrm{H}_{2}, \mathrm{O}_{2}$, and $\mathrm{N}_{2}$ were well separated, but $\mathrm{N}_{2} \mathrm{O}$ was retained on the column. For $\mathrm{N}_{2} \mathrm{O}$ analysis, the column was kept at $153^{\circ} \mathrm{C} ; \mathrm{H}_{2}$ could be analyzed at this temperature also, but it was only partially separated from $\mathrm{O}_{2}$ and $\mathrm{N}_{2}$, and the results were therefore subject to error if the amount of oxygen present due to leakage during the separation procedure was appreciable. Some results were obtained with a "HayeSep ${ }^{T M} \mathrm{Q}^{\prime}$ column at $50^{\circ} \mathrm{C}$, which also allowed $\mathrm{H}_{2}$ and $\mathrm{N}_{2} \mathrm{O}$ to be analyzed. The main drawback of this column is that a signal due to water vapor required lengthy time intervals between samples (about 30-40 min). Further details on the radiation sources, irradiation procedures, and gas analysis are provided in Appendix A.

\section{2b. Results and Discussion}

i. Yields of Radiolytic Generation of $\mathrm{H}_{2}$. The results in Fig. 1 show that the production of $\mathrm{H}_{2}$ from Solution $P$ is linear with dose, that is, $\mathrm{G}\left(\mathrm{H}_{2}\right)$ is independent of dose. No effect of dose ( $30-1000 \mathrm{krad}$ ) on $\mathrm{G}\left(\mathrm{H}_{2}\right)$ was found in Solution $P$ or Solution $P$ with the organics solutes. Figures 2-7 show also that within experimental error there is no effect of dose rate $(0.15-20$ $\mathrm{krad} / \mathrm{min}$ ) on $\mathrm{G}\left(\mathrm{H}_{2}\right)$ for these solutions.

Figures 8-12 show the effect of the concentration of the organic solute in Solution $\mathrm{P}$ on $\mathrm{G}\left(\mathrm{H}_{2}\right)$ for irradiations at $30^{\circ} \mathrm{C}$. The $\mathrm{G}$ value increases linearly with concentration of the organic, as we expect from the mechanism for $\mathrm{H}_{2}$ production and the model calculations. Figure 13 shows similar data for irradiation of Solution P with EDTA at $60^{\circ} \mathrm{C}$; in this case, the data do not seem to indicate a linear increase with concentration of EDTA. Model calculations do not predict a significant deviation from linearity. Because there is no apparent reason why the increase should be significantly nonlinear, it is likely that the deviation from linearity is due to an experimental error.

\footnotetext{
The following method was used to calculate G-values from the concentration of products:

$\mathrm{G}$ is the number of molecules of product per $100 \mathrm{eV}$ absorbed radiation.

where $\quad m_{g}=$ molecules of product per gram of solution,

$\mathrm{G}=100 \times \mathrm{m}_{\mathrm{g}} / \mathrm{D}$,

$\mathrm{D}=$ dose absorbed by the solution in $\mathrm{eV} / \mathrm{gram}$, and

$D=D_{d} \times\left(\varepsilon / \varepsilon_{d}\right) \times\left(d_{d} / d\right) \times 6.242 \times 10^{13}$,

where $\quad D_{d}=$ dose absorbed by the Fricke dosimeter in $\mathrm{rad}\left(1 \mathrm{rad}=6.242 \times 10^{13} \mathrm{eV} / \mathrm{gram}\right)$,

$\varepsilon=$ electron molarity of the solution,

$\varepsilon_{\mathrm{d}}=$ electron molarity of the dosimeter solution, and

$\mathrm{d}_{\mathrm{d}} / \mathrm{d}=$ density ratio, dosimeter to solution.
}

The electron molarity is the number of moles of electron on all molecules (solvent and solute) per liter of solution. 


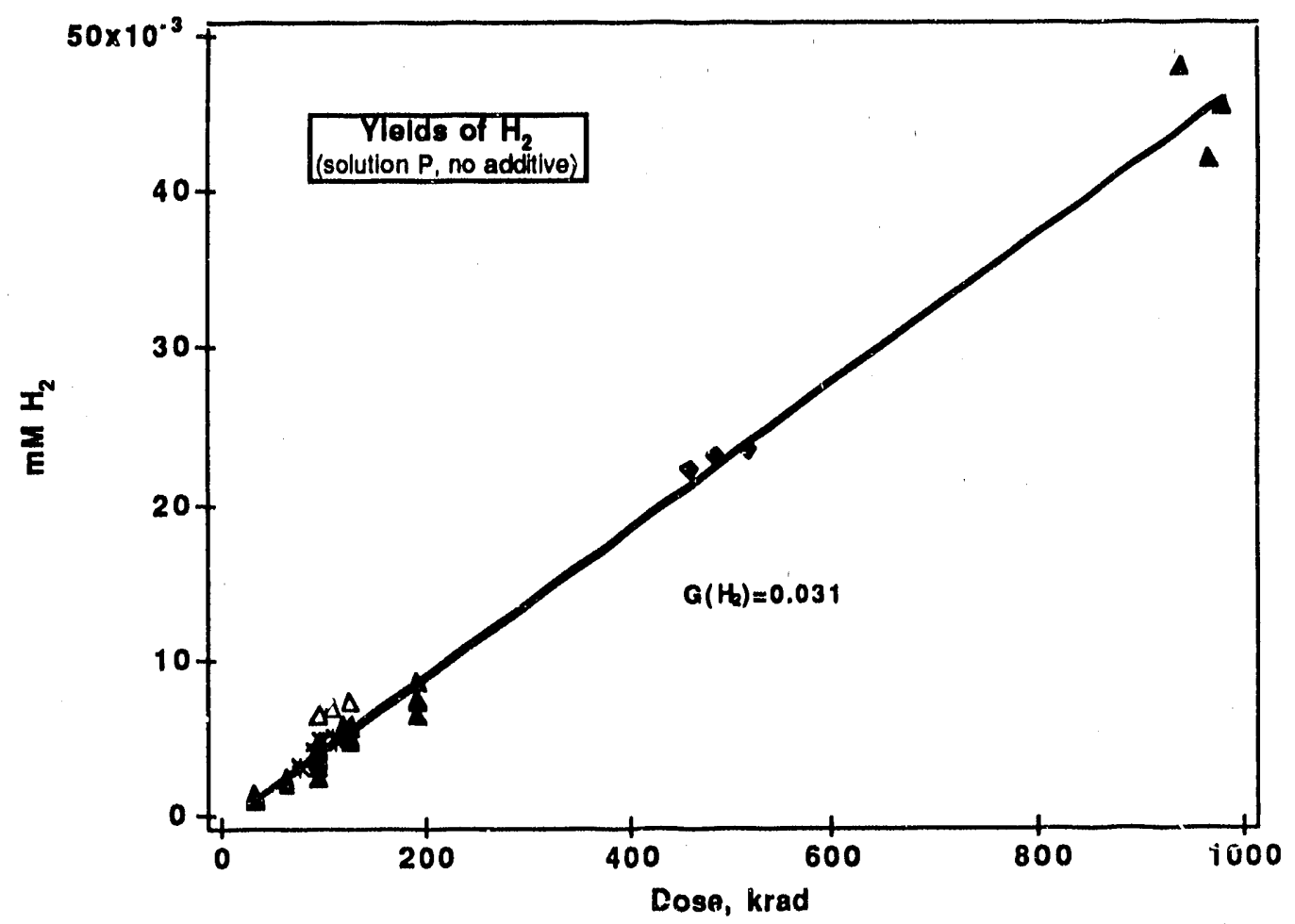

Figure 1. Concentration of $\mathrm{H}_{2}$ in millimoles per liter of solution vs. dose for Solution $\mathrm{P}$ at a dose rate of $0.41 \mathrm{krad} / \mathrm{min}$. The slope of the least-squares line provides the $G$ value after conversion of units. Samples were degassed before irradiation by bubbling with argon, except for the three diamond-shaped points, which were air-saturated samples. 


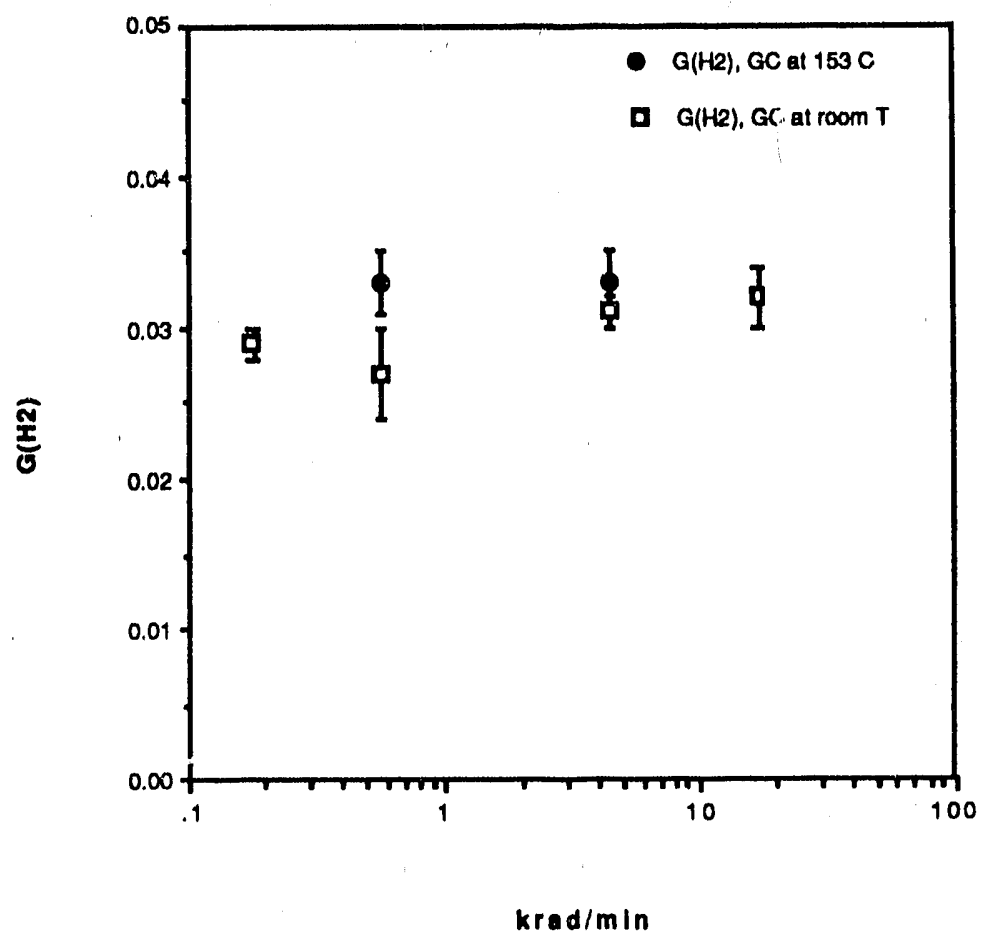

Figure 2. $\mathrm{G}\left(\mathrm{H}_{2}\right)$ vs. dose rate. Solution $\mathrm{P}$, irradiated at $30^{\circ} \mathrm{C}$ (molecular sieve $13 x$ column in $\mathrm{GC}$ for Figs. 2-7; temperatures in the legends refer to the temperatiure of the GC column).

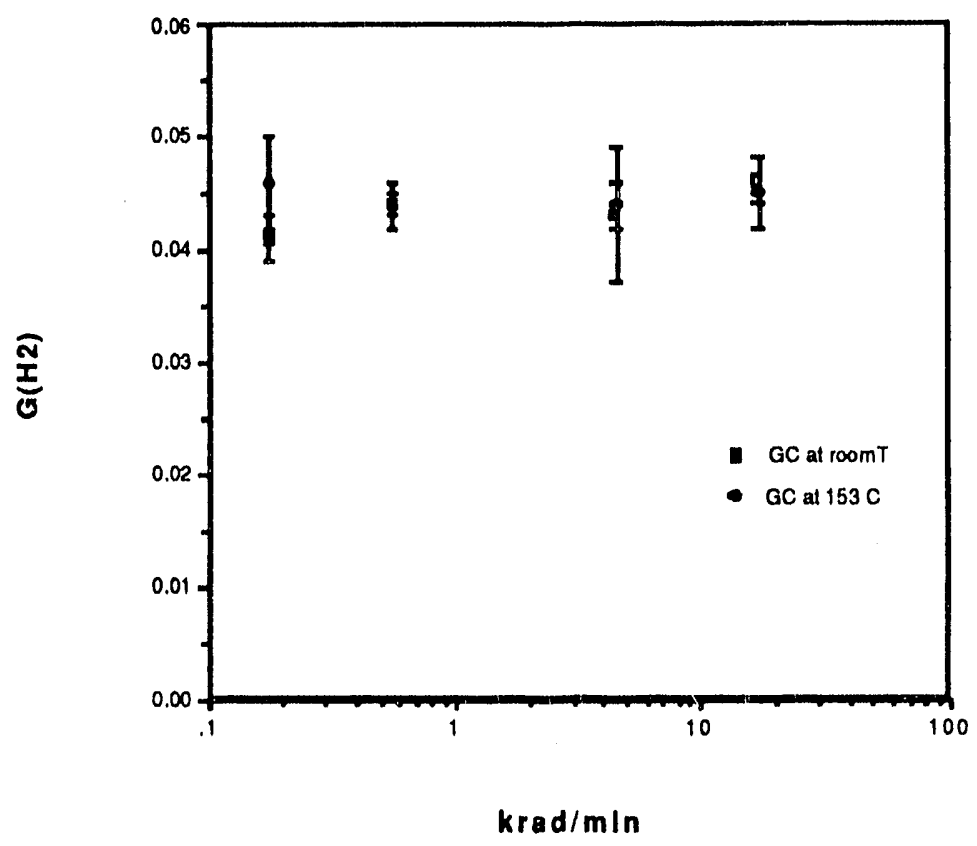

Figure 3. $\mathrm{G}\left(\mathrm{H}_{2}\right)$ vs. dose rate for Solution $\mathrm{P}$ with $0.085 \mathrm{M}$ EDTA, irradiated at $30^{\circ} \mathrm{C}$. 


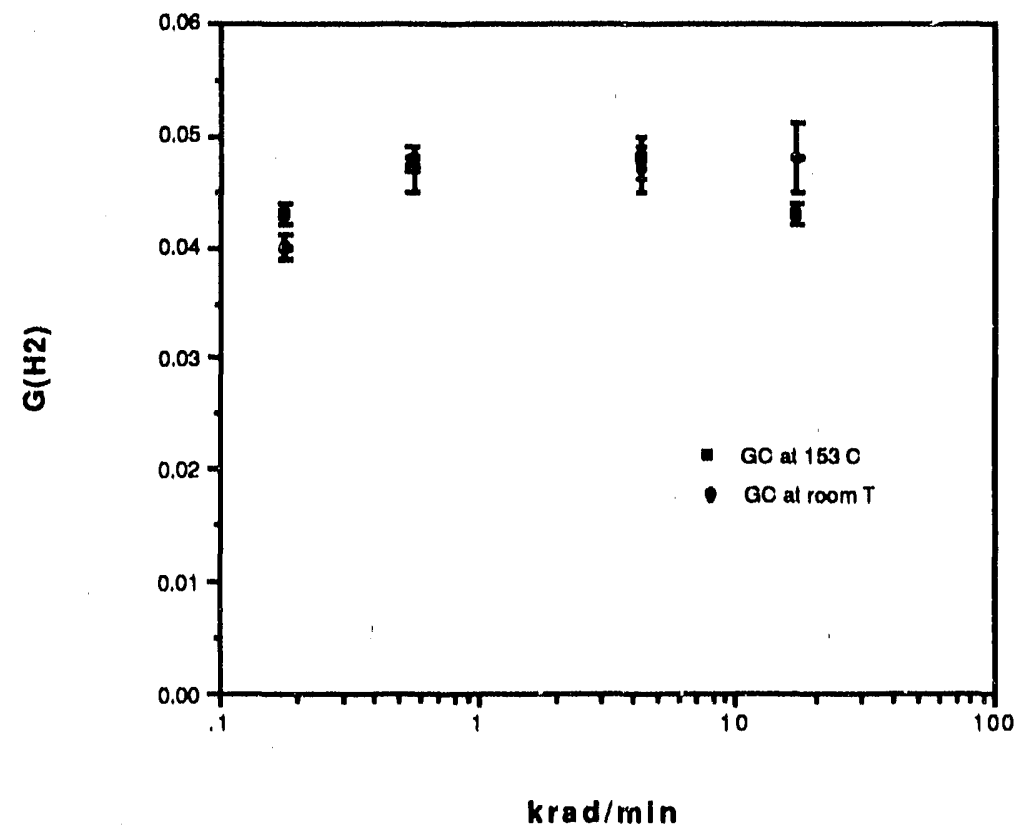

Figure 4. $\mathrm{G}\left(\mathrm{H}_{2}\right)$ vs. dose rate for Solution $\mathrm{P}$ with $0.085 \mathrm{M}$ HEDTA, irradiated at $30^{\circ} \mathrm{C}$.

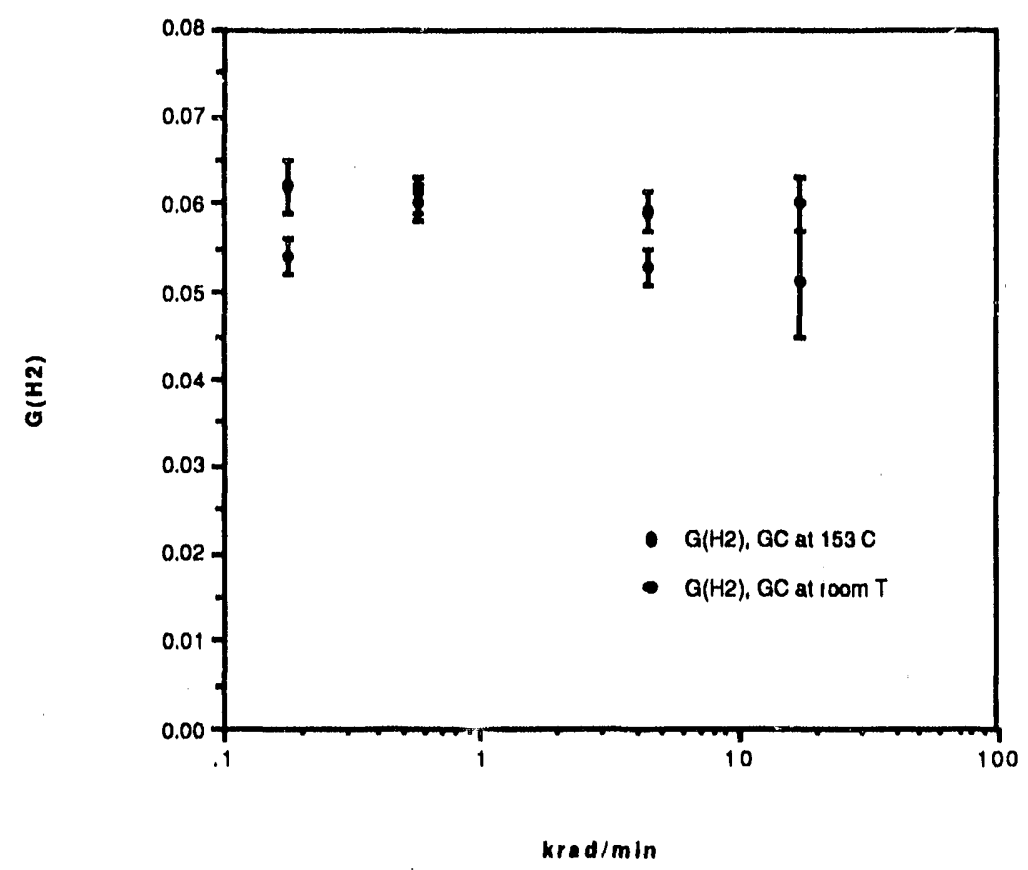

Figure 5. $\mathrm{G}\left(\mathrm{H}_{2}\right)$ vs. dose rate for Solution $\mathrm{P}$ with $0.085 \mathrm{M}$ each of EDTA and HEDTA, irradiated at $30^{\circ} \mathrm{C}$. 


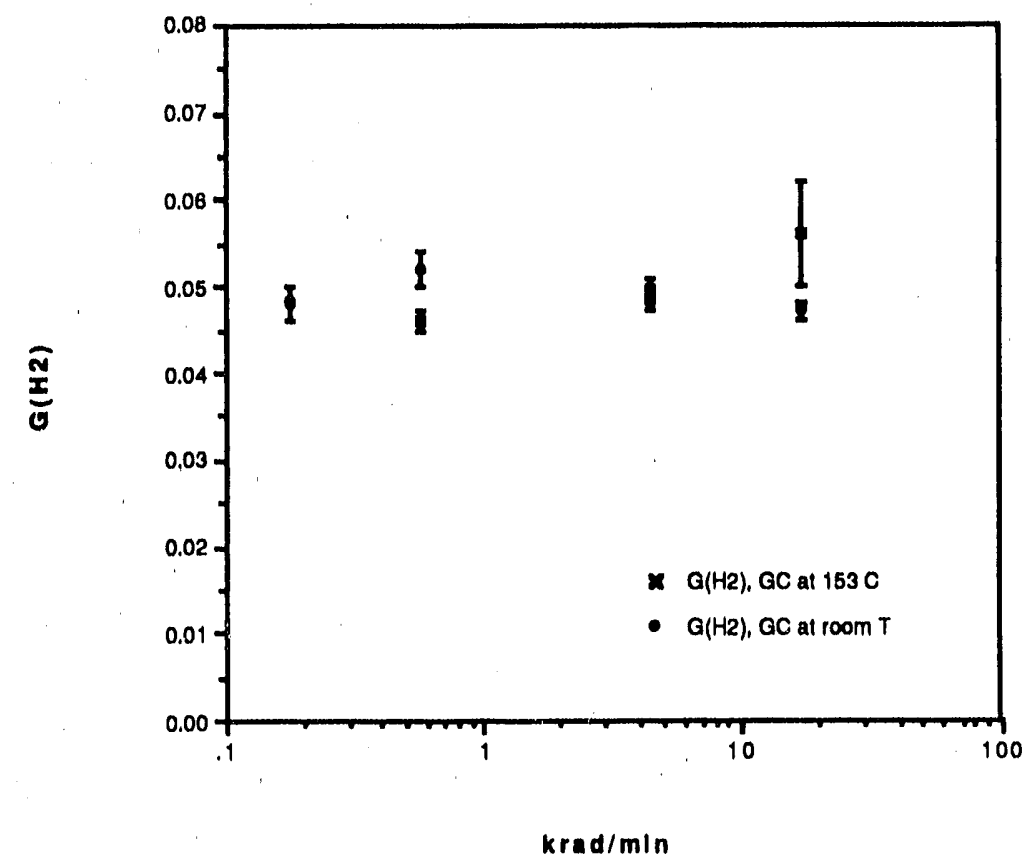

Figure 6. $\mathrm{G}\left(\mathrm{H}_{2}\right)$ vs. dose rate for Solution $\mathrm{P}$ with $0.34 \mathrm{M} \mathrm{IDA}$, irradiated at $30^{\circ} \mathrm{C}$.

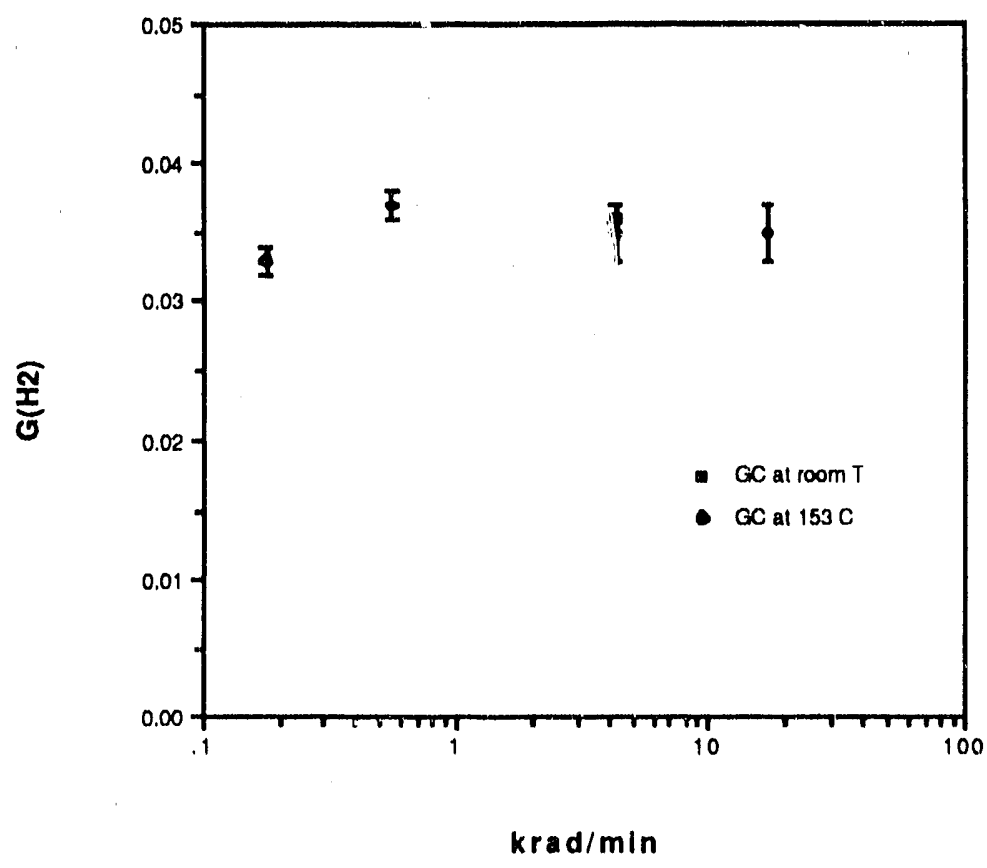

Figure 7. $\mathrm{G}\left(\mathrm{H}_{2}\right)$ vs. dose rate for Solution $\mathrm{P}$ with $0.17 \mathrm{M}$ citrate, irradiated at $30^{\circ} \mathrm{C}$. 


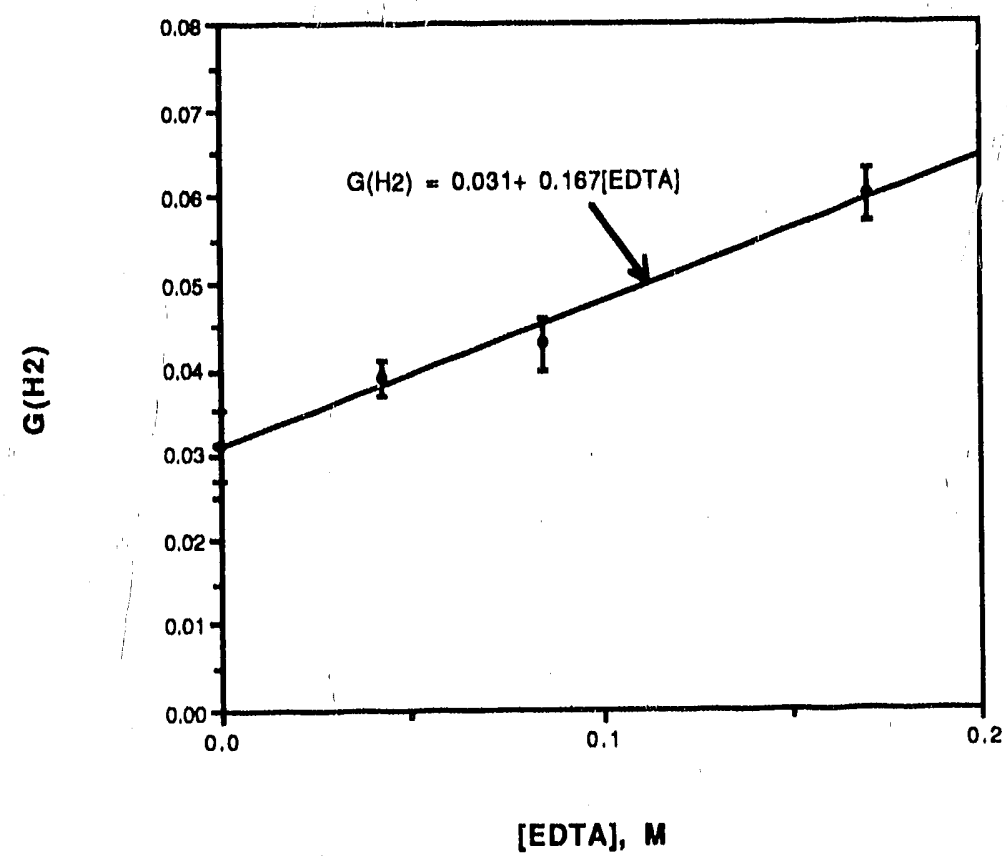

Figure 8. $\mathrm{G}\left(\mathrm{H}_{2}\right)$ vs. [ED'TA] in Solution P irradiated at $4.4 \mathrm{krad} / \mathrm{min}$ to $130 \mathrm{krad}$ dose at $30^{\circ} \mathrm{C}$.

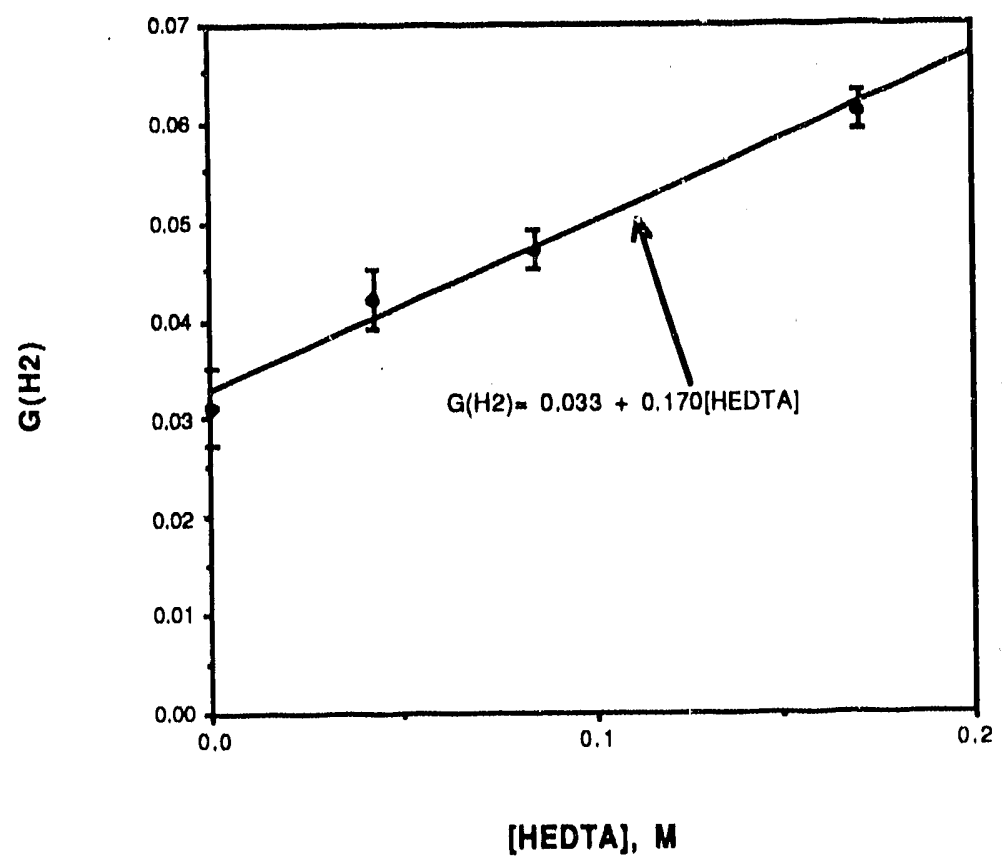

Figure 9. $\mathrm{G}\left(\mathrm{H}_{2}\right)$ vs. [HEDTA] in Solution $\mathrm{P}$ irradiated at $4.4 \mathrm{krad} / \mathrm{min}$ to $130 \mathrm{krad}$ dose at $30^{\circ} \mathrm{C}$. 


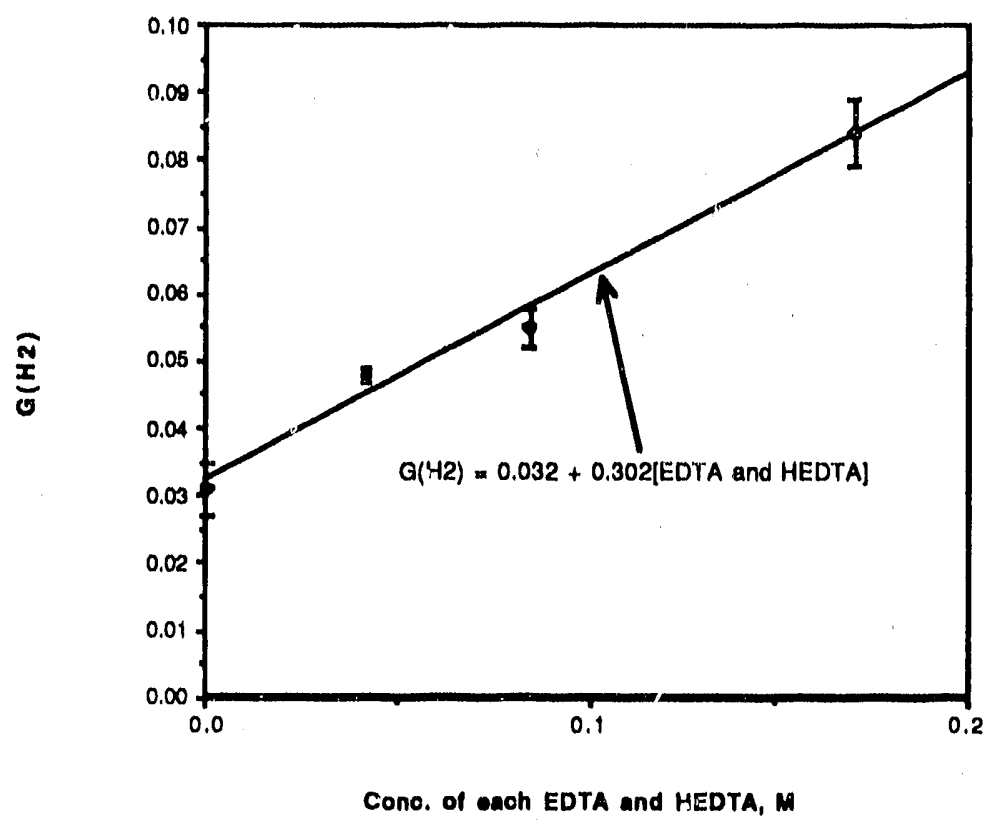

Figure 10. $\mathrm{G}\left(\mathrm{H}_{2}\right)$ vs. [EDTA] and [HEDTA] in Solution $P$ irradiated at $4.4 \mathrm{krad} / \mathrm{min}$ to $130 \mathrm{krad}$ at $30^{\circ} \mathrm{C}$.

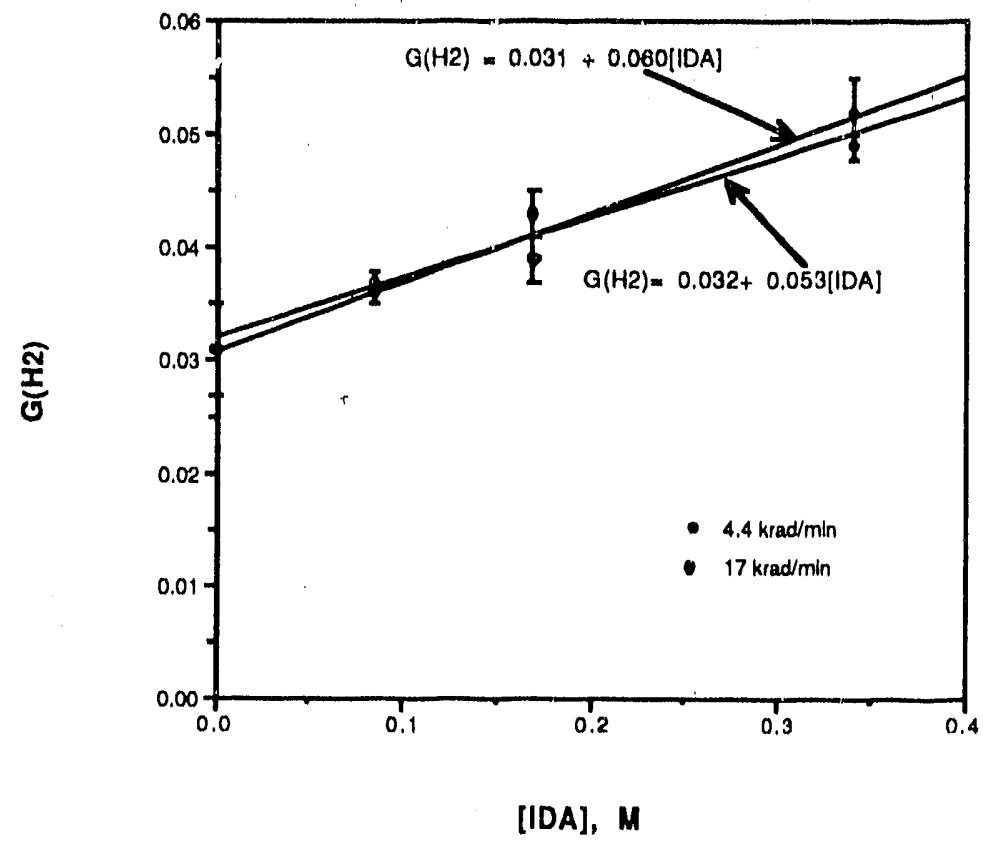

Figure 11. $\mathrm{G}\left(\mathrm{H}_{2}\right)$ vs. [IDA] in Solution P irradiated at 4.4 and $17 \mathrm{krad} / \mathrm{min}$ to $130 \mathrm{krad}$ dose at $30^{\circ} \mathrm{C}$. 


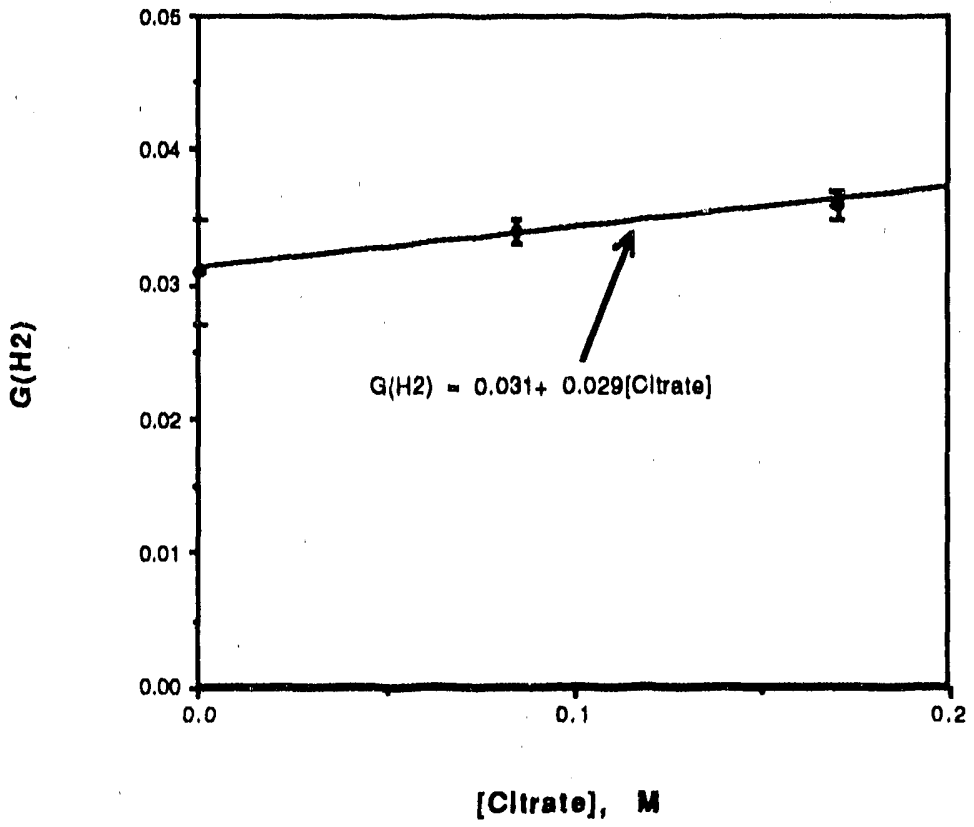

Figure 12. $\mathrm{G}\left(\mathrm{H}_{2}\right)$ vs. [citrate] in Solution $\mathrm{P}$ irradiated at $4.4 \mathrm{krad} / \mathrm{min}$ to $130 \mathrm{krad}$ dose at $30^{\circ} \mathrm{C}$.

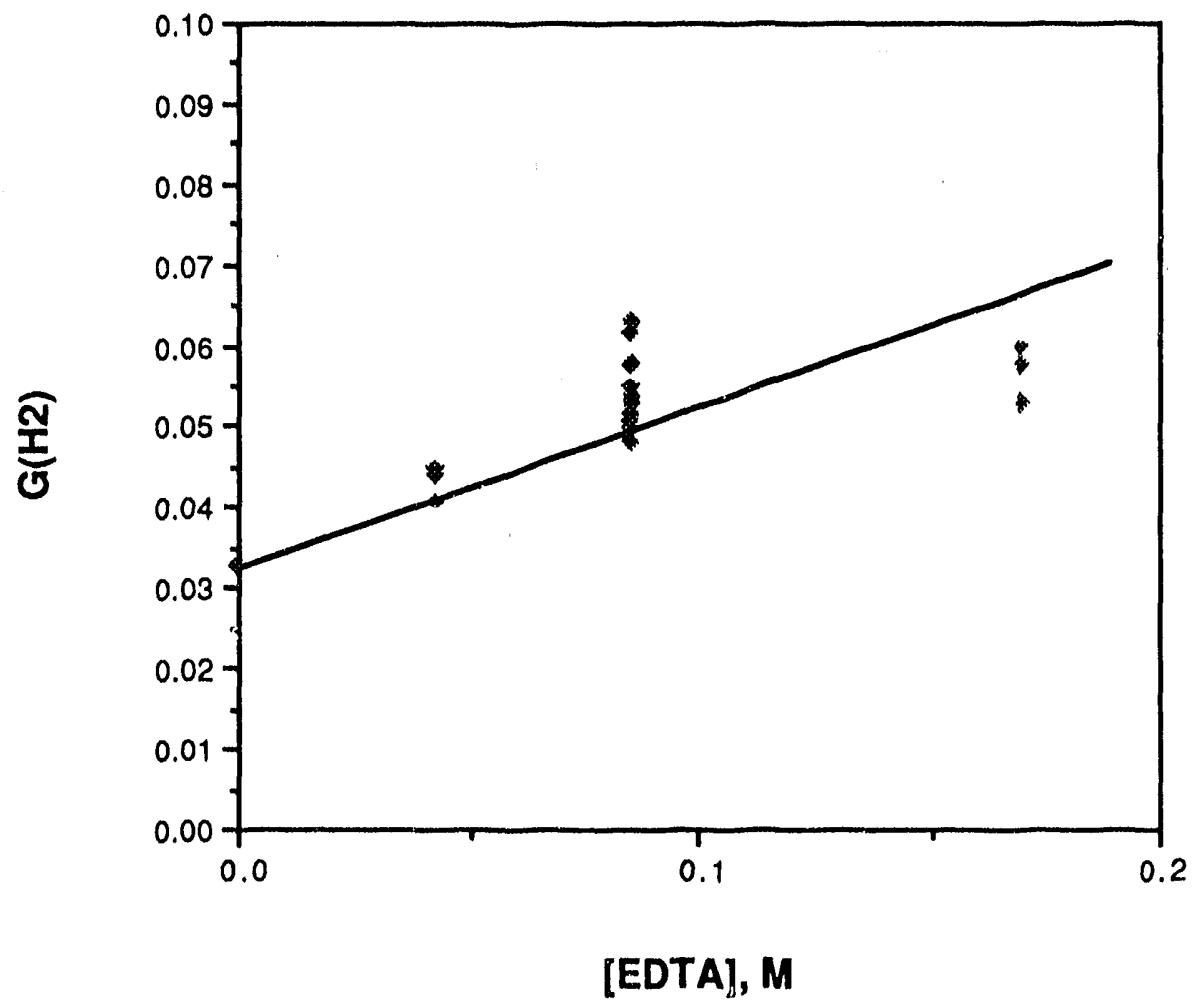

Figure 13. $\mathrm{G}\left(\mathrm{H}_{2}\right)$ vs. [EDTA] in Solution $\mathrm{P}$ irradiated at $60^{\circ} \mathrm{C}$ at $4.7 \mathrm{krad} / \mathrm{min}$ to $150 \mathrm{krad}$ (except for three samples at $0.085 \mathrm{M}$ that received $560 \mathrm{krad}$ ). 
The slopes of the lines in Figs. 8-13 were determined, and are referred to as $R$ values. $R$ represents a relative efficiency of an organic solute in increasing the hydrogen yield. The values of $R$ determined at $30^{\circ} \mathrm{C}$ are summarized in Table 1; for comparison, the number of $\mathrm{C}-\mathrm{H}$ and $\mathrm{N}-\mathrm{H}$ bonds in the organic molecule are given. It is seen that a qualitative positive correlation of $\mathrm{R}$ with the number of $\mathrm{C}-\mathrm{H}$ and $\mathrm{N}-\mathrm{H}$ bonds exists. The same correlation is shown graphically in Fig. 14. Note that the values of $\mathrm{R}$ represent only the slopes of Figs. 8-13. Thus, an additional amount of $\mathrm{H}_{2}$ must be added to calculate the total $\mathrm{G}\left(\mathrm{H}_{2}\right)$, due to the production of $\mathrm{H}_{2}$ in Solution $P$ in the absence of an organic additive $\left(\mathrm{G}\left(\mathrm{H}_{2}\right)=0.031\right)$. The correlation suggests that the probability of a molecule serving as a source for $\mathrm{H}_{2}$ increases with the number of hydrogen atoms (bound to $\mathrm{C}$ or $\mathrm{N}$ atoms only; labeled below $\eta_{\mathrm{x}-\mathrm{H}}$ ) in that molecule. From the straight line in Fig. 14, and using the experimentally determined $\mathrm{G}\left(\mathrm{H}_{2}\right)=0.031$ in Solution $\mathrm{P}$ without organic additives, the yield in the presence of organic solutes can be represented by:

$$
\mathrm{G}\left(\mathrm{H}_{2}\right)=0.031+0.013 \times \eta_{\mathrm{x}-\mathrm{H}} \times[\mathrm{RH}] .
$$

It should be emphasized that this equation is only of empirical value; it will be followed only for a background solution of the same composition as Solution P. Such an approximate correlation is to be expected from the mechanism of abstraction of $\mathrm{H}$ from the organic solute by radiolytically produced $\mathrm{H}$ atoms to yield $\mathrm{H}_{2}$.

In Table 2 we compare the results of $\mathrm{G}\left(\mathrm{H}_{2}\right)$ determinations at 30 and $60^{\circ} \mathrm{C}$; vaises are given for the single concentration shown in the tak'e of each organic solute. The value of $\mathrm{G}\left(\mathrm{H}_{2}\right)$ is seen to be larger at $60^{\circ} \mathrm{C}$ in all cases. Table 3 gi ' es a summary of R values obtained at 30 and $60^{\circ} \mathrm{C}$. The values at $60^{\circ} \mathrm{C}$ are based on results with only one concentration of organic additive, except in the case of EDTA (which is given in Fig. 13); hence, the $\mathrm{R}$ values at $60^{\circ} \mathrm{C}$ are apt to be less accurate.

Table 2 presents also results on a sample, designated as POI (containing $0.065 \mathrm{M}$ each of the sodiur. sults of EDTA and HEDTA, and $0.1 \mathrm{M}$ sodium citrate in Solution $\mathrm{P}$ ), that was pre-irradiated (31.5 Mrad at $0.51 \mathrm{krad} / \mathrm{min} ; 43$ days) and then used as starting material for further irradiations. An identical solution (labeled POC in Table 2) was not preirradiated but was otherwise treated identically as a control in case thermal degradation over 43 days led to any significant changes in the solution. Both solutions were degassed prior to the follow-up irradiation and after the preirradiation by bubbling with argon, as was normally done for other samples.

The results in Table 2 show that the preirradiation did not significantly alter the yields of $\mathrm{H}_{2}$ when irradiated at $30^{\circ} \mathrm{C}$, that is, the yields from Solutions POI and POC are about the same. The yield of $\mathrm{H}_{2}$ from irradiation of Solution $\mathrm{POC}$ at $60^{\circ} \mathrm{C}$ is very near to what is expected based on the yields from EDTA, HEDTA, and citrate at $60^{\circ} \mathrm{C}$. However, the yield from Solution POI following irradiation at $60^{\circ} \mathrm{C}$ is significantly higher than that from Solution POC. Only approximately $10 \%$ of the difference can be ascribed to the thermal production of $\mathrm{H}_{2}$ (which is enhanced by the preirradiation, as is discussed in Section 2b-vi below). Thus, the preirradiation causes a 20-25\% increase in the radiolytic yield of $\mathrm{H}_{2}$.

Table 3 indicates that the efficiency, $\mathrm{R}$, of $\mathrm{H}_{2}$ production by the organic solutes increases at $60^{\circ} \mathrm{C}$ for all of them except citrate. In the framework of the mechanism for radiolytic hydrogen production (hydrogen abstraction by $\mathrm{H}$ atoms from the organic solute), this result indicates that the rate of the hydrogen abstraction reaction increases more upon increasing the temperature than the increase in the rate of the other reactions with $\mathrm{H}$ atoms (most dominating is the reaction with nitrite). This is reflected in the rate constant determinations described in Section $2 \mathrm{~b}$-ii below.

The effects of $\mathrm{Na}_{2} \mathrm{CO}_{3}$ and $\mathrm{Na}_{2} \mathrm{~S}$ on the yield of $\mathrm{H}_{2}$ from Solution $\mathrm{P}$ were determined also. To determine the effect of $\mathrm{Na}_{2} \mathrm{CO}_{3}$, which is present in 101-SY and in the WHC standard waste solution ${ }^{5}$ but is absent in our standard solution, $0.4 \mathrm{M} \mathrm{Na}_{2} \mathrm{CO}_{3}$ was added to Solution $\mathrm{P}$ containing $0.17 \mathrm{M}$ EDTA. This solution was irradiated at 30 and $60^{\circ} \mathrm{C}$ at $4.2 \mathrm{krad} / \mathrm{min}$ to a dose of $150 \mathrm{krad}$. 
Table 1. Relative efficiencies for $\mathrm{H}_{2}$ production from radiolysis of Solution $\mathrm{P}$ (irradiations at $\left.30^{\circ} \mathrm{C}\right)$.

\begin{tabular}{lccc}
\hline Additive & $\begin{array}{c}\mathrm{R} \\
\left(\mathrm{G}\left(\mathrm{H}_{2}\right) / \mathrm{M}\right)\end{array}$ & $\begin{array}{c}\text { No. of } \\
\mathrm{C}-\mathrm{H} \text { bonds }\end{array}$ & $\begin{array}{c}\text { No. of } \\
\text { N-H bonds }\end{array}$ \\
\hline HEDTA & 0.170 & 14 & 0 \\
EDTA & 0.167 & 12 & 0 \\
EDTA+HEDTA & $0.151 *$ & 13 (avg) & 0 \\
NTA & 0.094 & 6 & 0 \\
IDA & 0.056 & 4 & 1 \\
Citrate & 0.029 & 4 & 0 \\
Glycine & 0.038 & 2 & 2 \\
Glycolate & 0.055 & 2 & 0 \\
\hline
\end{tabular}

*Equimolar concentrations of EDTA and HEDTA; slope divided by two to obtain R.

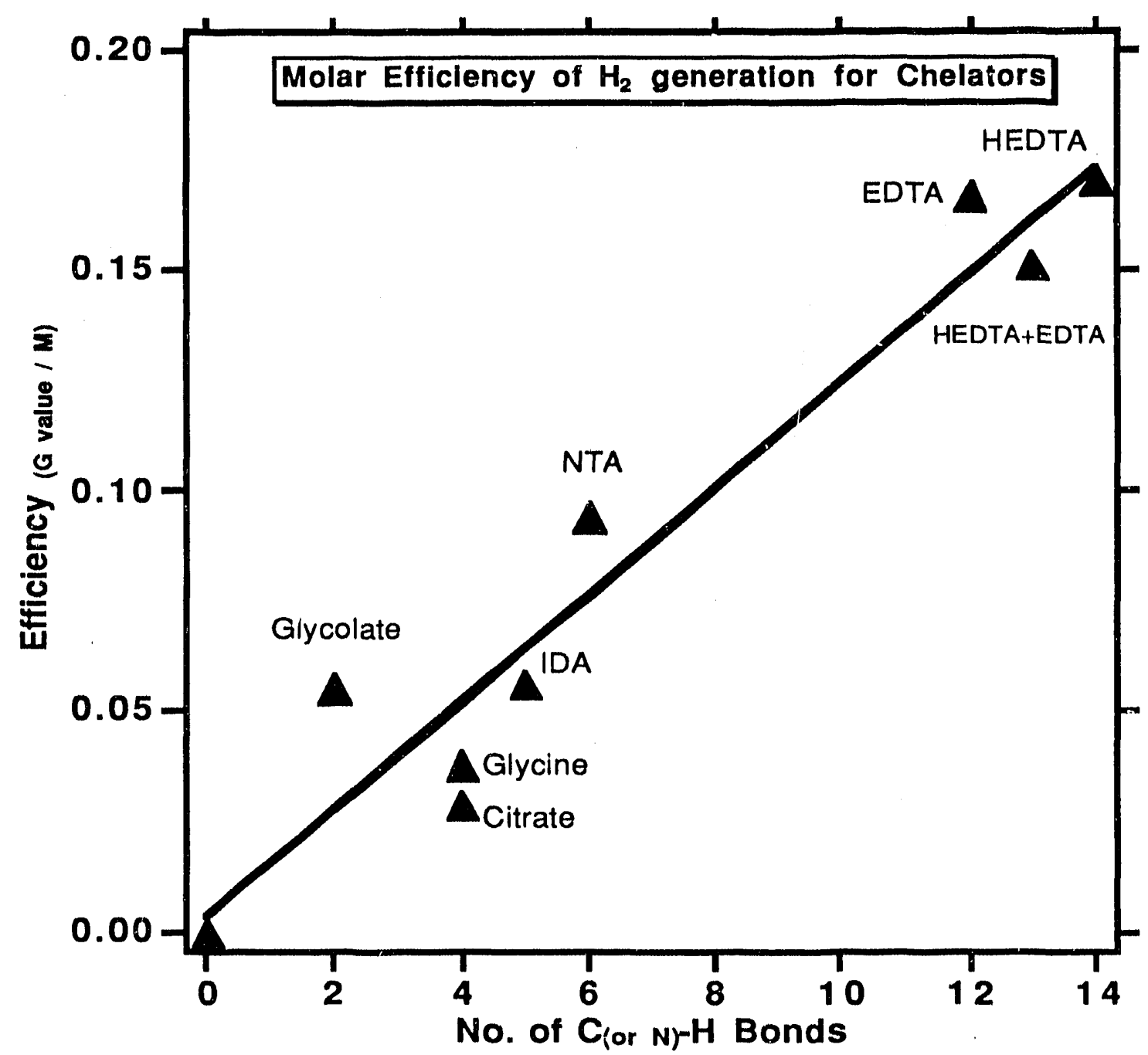

Figure 14. The dependence of the efficiency of $\mathrm{H}_{2}$ generation (in $\mathrm{G}$ values per mole) of the various organic solutes on the hydrogen content of the compound. 
Table 2. Experimental results ${ }^{\mathrm{a}}$ for $\mathrm{G}\left(\mathrm{H}_{2}\right)$ at $60^{\circ} \mathrm{C}$ and comparison with results at $30^{\circ} \mathrm{C}$.

\begin{tabular}{ll|ccc}
\hline Additive & $\begin{array}{c}{[\mathrm{RH}]} \\
\mathrm{M}\end{array}$ & $\begin{array}{c}\mathrm{G}\left(\mathrm{H}_{2}\right) \\
60{ }^{\circ} \mathrm{C}\end{array}$ & $\begin{array}{c}\mathrm{G}\left(\mathrm{H}_{2}\right) \\
30^{\circ} \mathrm{C}\end{array}$ & $\begin{array}{c}\text { Ratio } \\
\mathrm{G}_{60}{ }^{\circ} \mathrm{C}\end{array}$ \\
\hline None & 0 & 0.033 & 0.031 & 1.06 \\
EDTA & 0.085 & 0.053 & 0.045 & 1.18 \\
HEDTA & 0.085 & 0.054 & 0.045 & 1.15 \\
NTA & 0.17 & 0.054 & 0.047 & 1.15 \\
DA & 0.17 & 0.045 & 0.041 & 1.10 \\
Citrate & 0.17 & 0.037 & 0.036 & 1.03 \\
Glycine & 0.3 & 0.045 & 0.042 & 1.07 \\
Glycolate & 0.3 & 0.055 & 0.048 & 1.15 \\
POC & $b$ & 0.063 & 0.045 & 1.40 \\
POI & $c$ & 0.080 & 0.047 & 1.70 \\
\hline
\end{tabular}

${ }^{a}$ Samples received approximately $140 \mathrm{krad}$ in 30 -min irradiations.

$b_{\text {Solution } P}$ with $0.065 \mathrm{M}$ EDTA, $0.065 \mathrm{M}$ HEDTA (sodium salts), and $0.1 \mathrm{M}$ sodium citrate aged at $30^{\circ} \mathrm{C}$ for the same period of time as Solution POI. $c$

CSame as $b$, but after $31.5 \mathrm{Mrad}$ at $0.51 \mathrm{krad} / \mathrm{min}$ preirradiation.

Table 3. Comparison of the efficiency parameters $R$ at 30 and $60^{\circ} \mathrm{C}$.

\begin{tabular}{|c|c|c|c|}
\hline Additive & $\begin{array}{c}\mathrm{R} \\
30^{\circ} \mathrm{C} \\
\left(\mathrm{G}\left(\mathrm{H}_{2}\right) / \mathrm{M}\right)\end{array}$ & $\begin{array}{c}\mathrm{R} \\
60^{\circ} \mathrm{C} \\
\left(\mathrm{G}\left(\mathrm{H}^{\circ}\right) / \mathrm{M}\right)\end{array}$ & $\begin{array}{l}\text { Ratio } \\
\mathrm{R}_{60} \\
\mathrm{R}_{30}\end{array}$ \\
\hline EDTA & 0.167 & 0.20 & 1.20 \\
\hline HEDTA & 0.170 & 0.25 & 1.45 \\
\hline NTA & 0.094 & 0.124 & 1.31 \\
\hline IDA & 0.056 & 0.071 & 1.26 \\
\hline Citrate & 0.029 & 0.024 & 0.81 \\
\hline Glycine & 0.038 & 0.040 & 1.05 \\
\hline Glycolate & 0.055 & 0.073 & 1.33 \\
\hline
\end{tabular}

The values of $\mathrm{G}\left(\mathrm{H}_{2}\right)$ obtained are 0.047 at $30^{\circ} \mathrm{C}$ and 0.059 at $60^{\circ} \mathrm{C}$. Using results from Figs. 8 and 13 for solutions of $0.17 \mathrm{M}$ EDTA in Solution $\mathrm{P}$ (with no $\mathrm{Na}_{2} \mathrm{CO}_{3}$ ), values of 0.059 at $30^{\circ} \mathrm{C}$ and 0.066 at $60^{\circ} \mathrm{C}$ (note, as discussed above, that there is an appreciable uncertainty in the latter value) are expected if there is no effect of $\mathrm{Na}_{2} \mathrm{CO}_{3}$. Apparently, $\mathrm{Na}_{2} \mathrm{CO}_{3}$ slightly inhibits the formation of $\mathrm{H}_{2}$ at $30^{\circ} \mathrm{C}$, and has no effect, within experimental error, at $60^{\circ} \mathrm{C}$. The apparent inhibition effect is unexpected because $\mathrm{Na}_{2} \mathrm{CO}_{3}$ is not expected to react with hydrogen atoms.

Sulfur has been considered ${ }^{6}$ as a possible additive to inhibit $\mathrm{H}_{2}$ formation. In basic solutions it will exist as a polysulfide. We, therefore, measured $\mathrm{H}_{2}$ yields in solutions of $0.17 \mathrm{M}$ EDTA in Solution P containing 0.01 and $0.1 \mathrm{M} \mathrm{Na} 2 \mathrm{~S}$, irradiated at $4.2 \mathrm{krad} / \mathrm{min}$ to a dose of $130 \mathrm{krad}$. In this solution $\mathrm{Na}_{2} \mathrm{~S}$ will be partially oxidized to polysulfide but the relative ratio of $S$ to $\mathrm{S}^{2-}$ has not been determined. The results are shown in Table 4. These results show that $\mathrm{Na}_{2} \mathrm{~S}$ increases the yield of $\mathrm{H}_{2}$. A likely explanation of this is the reaction:

$$
\mathrm{H}+\mathrm{HS}^{-} \rightarrow \mathrm{H}_{2}+\mathrm{S}^{-} \text {. }
$$


Table 4. The effect of $\mathrm{Na}_{2} \mathrm{~S}$ on the yield of $\mathrm{H}_{2}$ in Solution $\mathrm{P}$ with $0.17 \mathrm{M}$ EDTA.

\begin{tabular}{ccl}
\hline Temp., ${ }^{\circ} \mathrm{C}$ & {$\left[\mathrm{Na}_{2} \mathrm{~S}\right], \mathrm{M}$} & $\mathrm{G}\left(\mathrm{H}_{2}\right)$ \\
\hline 30 & 0 & $0.059^{*}$ \\
30 & 0.01 & 0.057 \\
30 & 0.1 & 0.074 \\
\hline 60 & 0 & $0.066^{* *}$ \\
60 & 0.01 & $0.076,0.063$ \\
60 & 0.1 & $0.093,0.083$ \\
\hline
\end{tabular}

*From Fig. 8.

**From the slope of the line in Fig. 13; see discussion of error limits in text.

ii. Rate Constants for $\mathbf{H}$ Abstraction. The most reasonable explanation for the increase in the radiolytic yield of $\mathrm{H}_{2}$ by the organic solutes $(\mathrm{RH})$ is reaction 1 .

$$
\mathrm{H}+\mathrm{RH} \rightarrow \mathrm{H}_{2}+\mathrm{R} \quad \text { rate constant }=\mathrm{k}_{1}
$$

Therefore, experiments were conducter' to measure the rate constants of these reactions under conditions of high $\mathrm{pH}$ and high ionic strength. As will be shown below, this mechanism explains the radiolytic generation of $\mathrm{H}_{2}$. Hence, these rate constants will be useful in our model calculations under various scenarios. The rate constants were determined by measuring the yield of $\mathrm{H}_{2}$ as a function of concentration of the organic solute in a solution containing $0.1 \mathrm{M} \mathrm{NaOH}, 1 \mathrm{mM}$ $\mathrm{NaNO}_{3}$, and $1 \mathrm{M} \mathrm{NaCl}$. The low nitrate concentration used is necessary only to scavenge $e_{\mathrm{aq}}^{-}$and prevent $\mathrm{H}_{2}$ generation by the reactions of the latter; the high-chloride concentration was added to maintain high ionic strength. The relevant reactions in this system are reactions 1-3.

$$
\begin{array}{ll}
\mathrm{H}+\mathrm{OH}^{-} \rightarrow \mathrm{e}_{\mathfrak{a q}}^{-} & \text {rate constant }=\mathrm{k}_{2} \\
\mathrm{H}+\mathrm{NO}_{\overline{3}}^{-} \rightarrow \mathrm{NO}_{2}+\mathrm{OH}^{-} & \text {rate constant }=\mathrm{k}_{3}
\end{array}
$$

The data frorn which the rate constants, $\mathbf{k}_{1}$, were determined are shown in Figs. 15-24. The curves in these figures are calculated using equation I with values of $k_{1}$ and $G(H)$ selected to obtain a visual "best fit" (see below).

$$
\mathrm{G}\left(\mathrm{H}_{2}\right)=\mathrm{G}\left(\mathrm{H}_{2}\right)^{0}+\mathrm{G}(\mathrm{H}) \cdot \frac{\mathrm{k}_{1}[\mathrm{RH}]}{\mathrm{k}_{1}[\mathrm{RH}]+\mathrm{k}_{2}\left[\mathrm{OH}^{-}\right]+\mathrm{k}_{3}\left[\mathrm{NO}_{3}^{-}\right]}
$$

Equation I results from a consideration of the reactions competing for $\mathrm{H} \cdot$ atoms; $\mathrm{G}\left(\mathrm{H}_{2}\right)^{0}$ is the limiting yield of $\mathrm{H}_{2}$ at zero concentration of $\mathrm{RH}$; this was measured five times in the $30^{\circ} \mathrm{C}$ runs, and a value of $0.395 \pm 0.014$ (average deviation) was obtained. This is somewhat lower than the value of 0.43 expected from the literature. ${ }^{1}$ At $60^{\circ} \mathrm{C}$, a value of $\mathrm{G}\left(\mathrm{H}_{2}\right)^{0}$ of $0.46 \pm 0.02$ was obtained from several determinations. These experimental values of $\mathrm{G}\left(\mathrm{H}_{2}\right)^{0}$ have been used in Figs. 15-24 for the determination of the values of $\mathrm{G}(\mathrm{H})$ and $\mathrm{k}_{1}$ for each organic solute. The values of $\mathrm{k}_{2}$ at $30^{\circ} \mathrm{C}\left(3.33 \times 10^{7} \mathrm{M}^{-1} \mathrm{~s}^{-1}\right)$ and $60^{\circ} \mathrm{C}\left(1.31 \times 10^{8} \mathrm{M}^{-1} \mathrm{~s}^{-1}\right)$ are available from the literature. ${ }^{7}$ The small value of $\mathrm{k}_{3}$ at $30^{\circ} \mathrm{C}\left(1.4 \times 10^{6} \mathrm{M}^{-1} \mathrm{~s}^{-1}\right)$ and the low $\mathrm{NO}_{3}^{-}$concentration make its reaction with $\mathrm{H}$ atoms negligible at $30^{\circ} \mathrm{C}$. The temperature dependence of $\mathrm{k}_{3}$ has not been measured, so $\mathrm{k}_{3}$ was assumed to be unchanged at $60^{\circ} \mathrm{C}$. Even if it were to increase severalfold, its effect would still be ncgligible. 


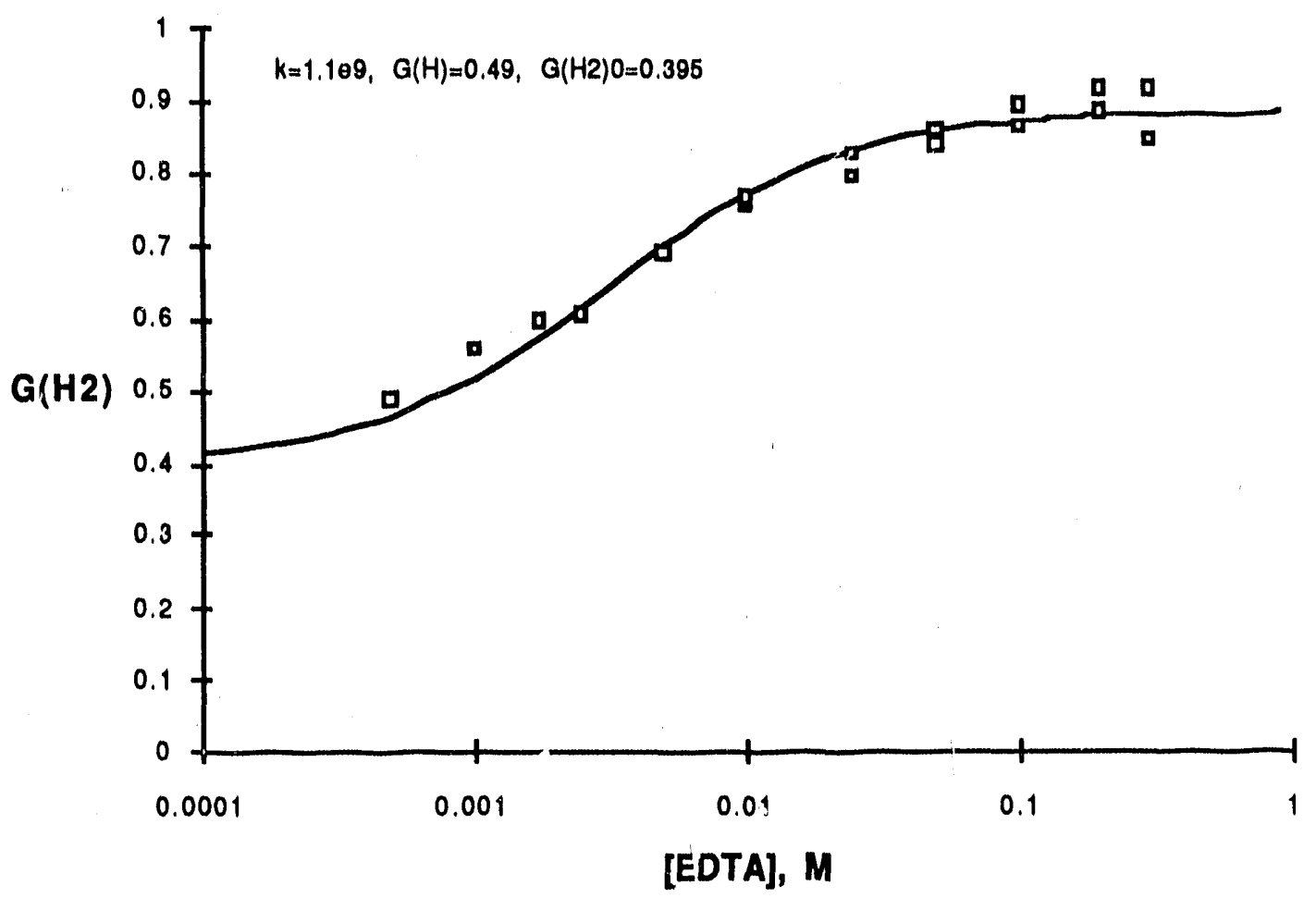

Figure 15. $\mathrm{G}\left(\mathrm{H}_{2}\right)$ at $30^{\circ} \mathrm{C}$ vs. [EDTA] in aqueous $0.1 \mathrm{M} \mathrm{NaOH}, 1 \mathrm{M} \mathrm{NaCl}, 1.0 \mathrm{mM} \mathrm{NaNO}$ solution.

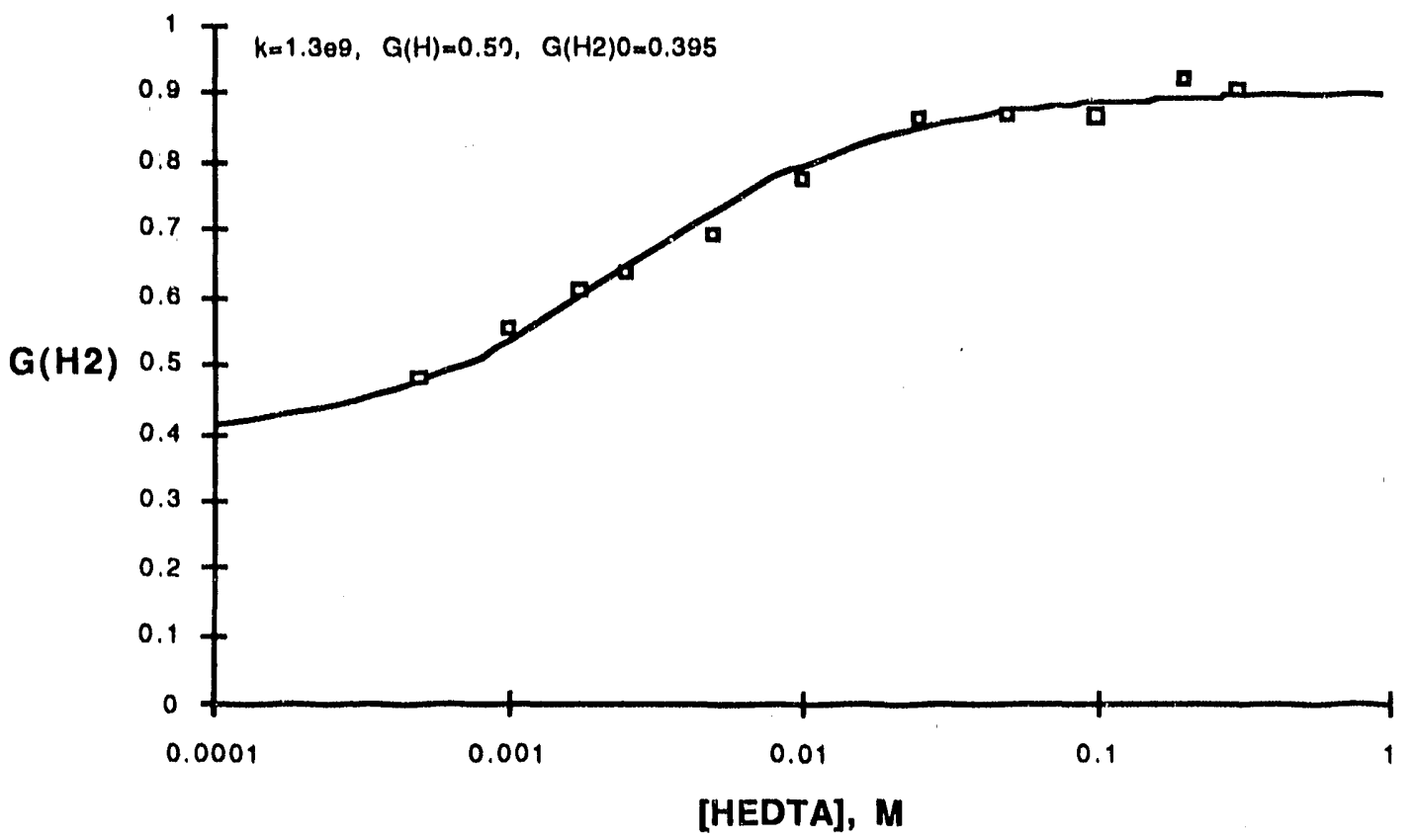

Figure 16. $\mathrm{G}\left(\mathrm{H}_{2}\right)$ at $30^{\circ} \mathrm{C}$ vs. [HEDTA] in aqueous $0.1 \mathrm{M} \mathrm{NaOH}, 1 \mathrm{M} \mathrm{NaCl}, 1.0 \mathrm{mM} \mathrm{NaNO}_{3}$ solution 


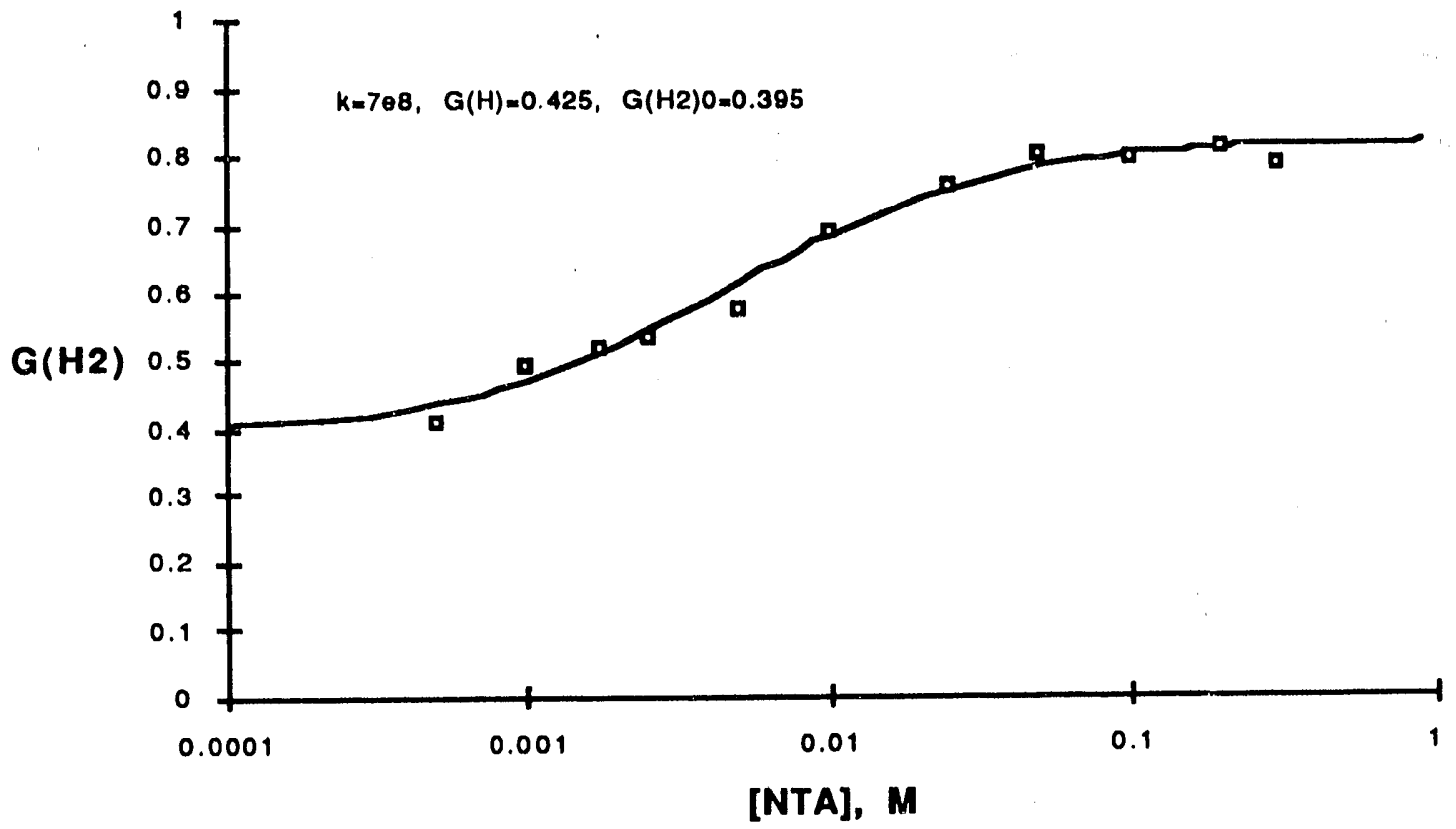

Figure 17. $\mathrm{G}\left(\mathrm{H}_{2}\right)$ at $30^{\circ} \mathrm{C}$ vs. [NTA] in aqueous $0.1 \mathrm{M} \mathrm{NaOH}, 1 \mathrm{M} \mathrm{NaCl}, 1.0 \mathrm{mM} \mathrm{NaNO}$ solution.

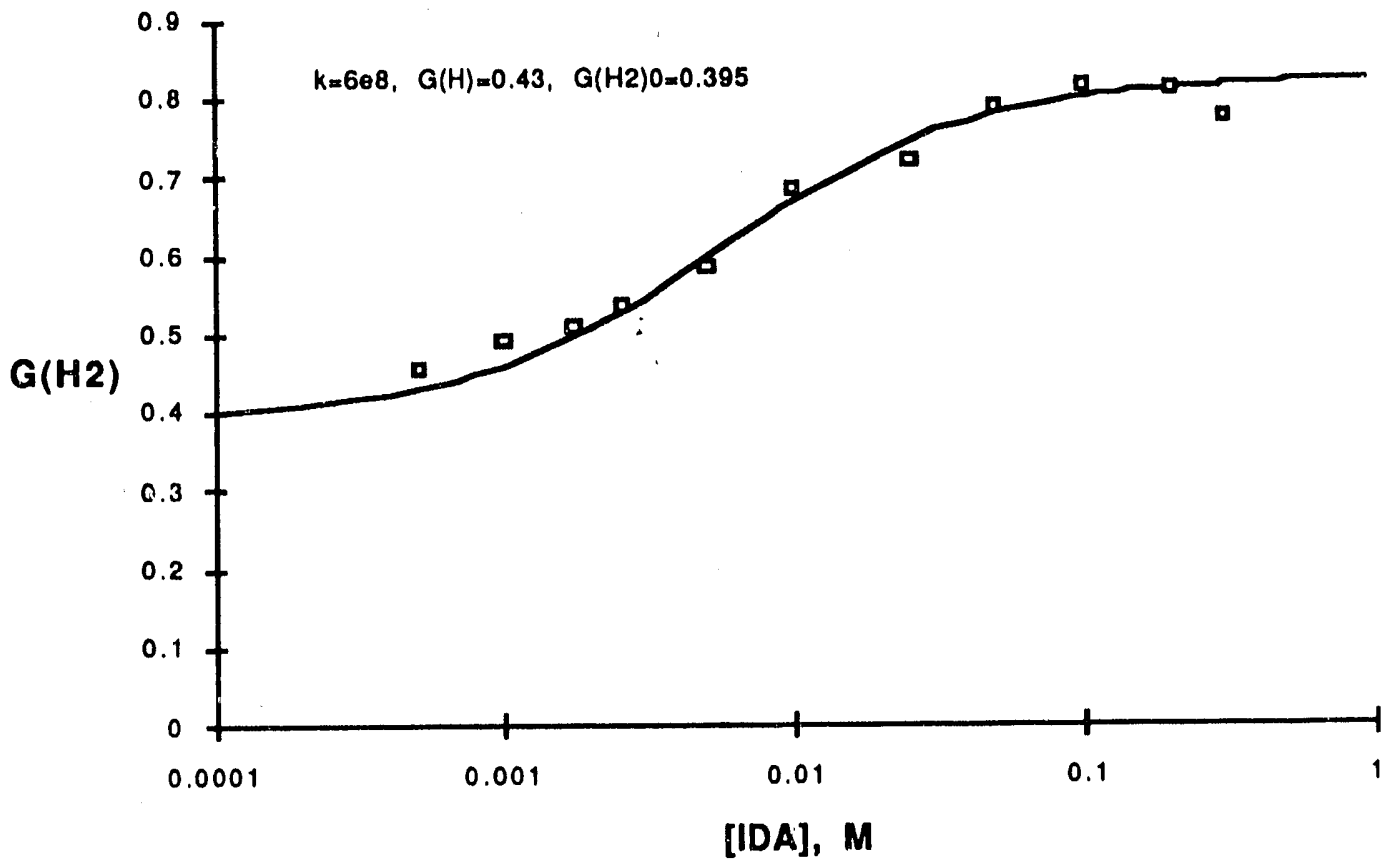

Figure 18. $\mathrm{G}\left(\mathrm{H}_{2}\right)$ at $30^{\circ} \mathrm{C}$ vs. [IDA] in aqueous $0.1 \mathrm{M} \mathrm{NaOH}, 1 \mathrm{M} \mathrm{NaCl}, 1.0 \mathrm{mM} \mathrm{NaNO}$ solution. 


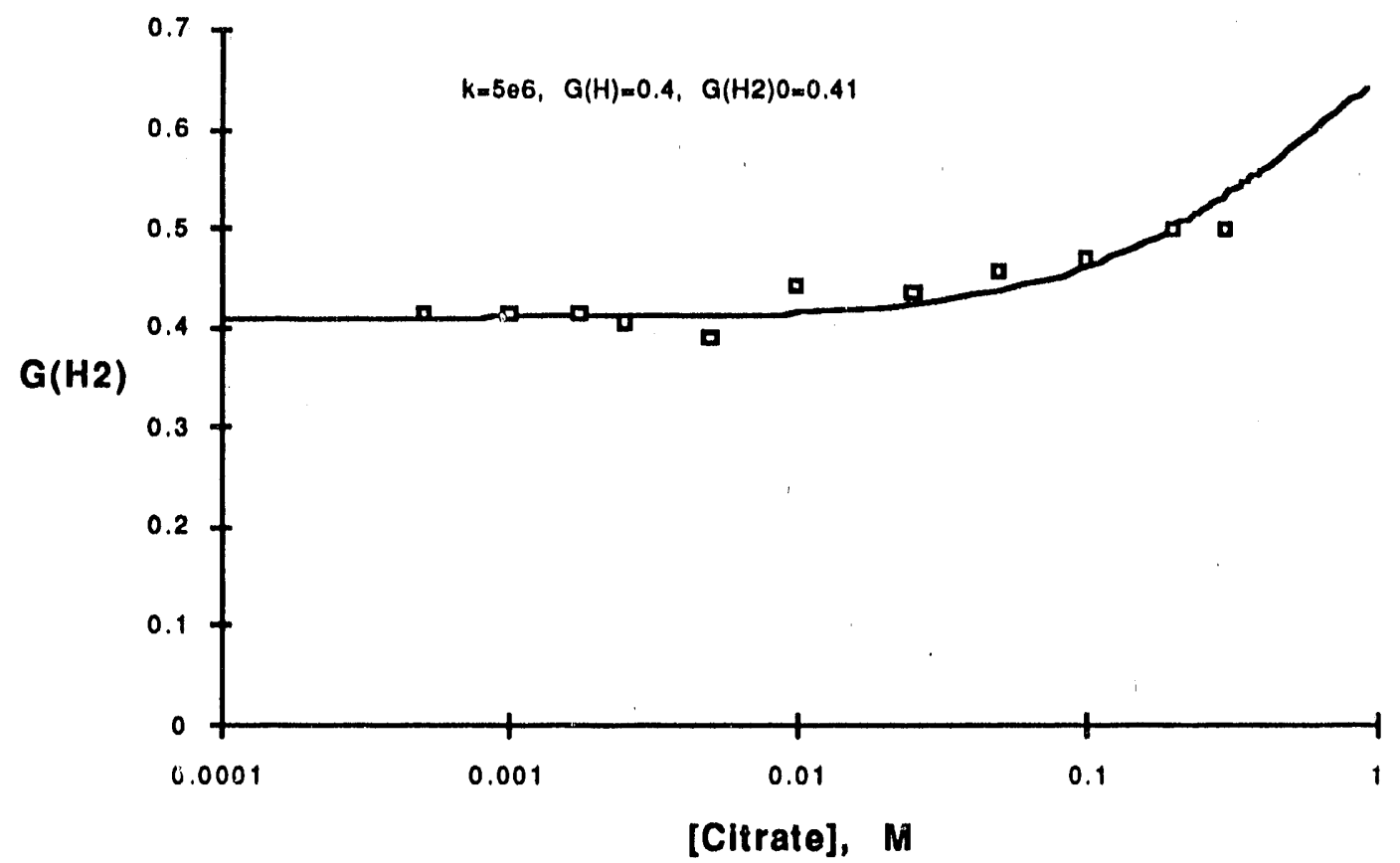

Figure 19. $\mathrm{G}\left(\mathrm{H}_{2}\right)$ at $30^{\circ} \mathrm{C}$ vs. [citrate] in aqueous $0.1 \mathrm{M} \mathrm{NaOH}, 1 \mathrm{M} \mathrm{NaCl}, 1.0 \mathrm{mM} \mathrm{NaNO}_{3}$ solution.

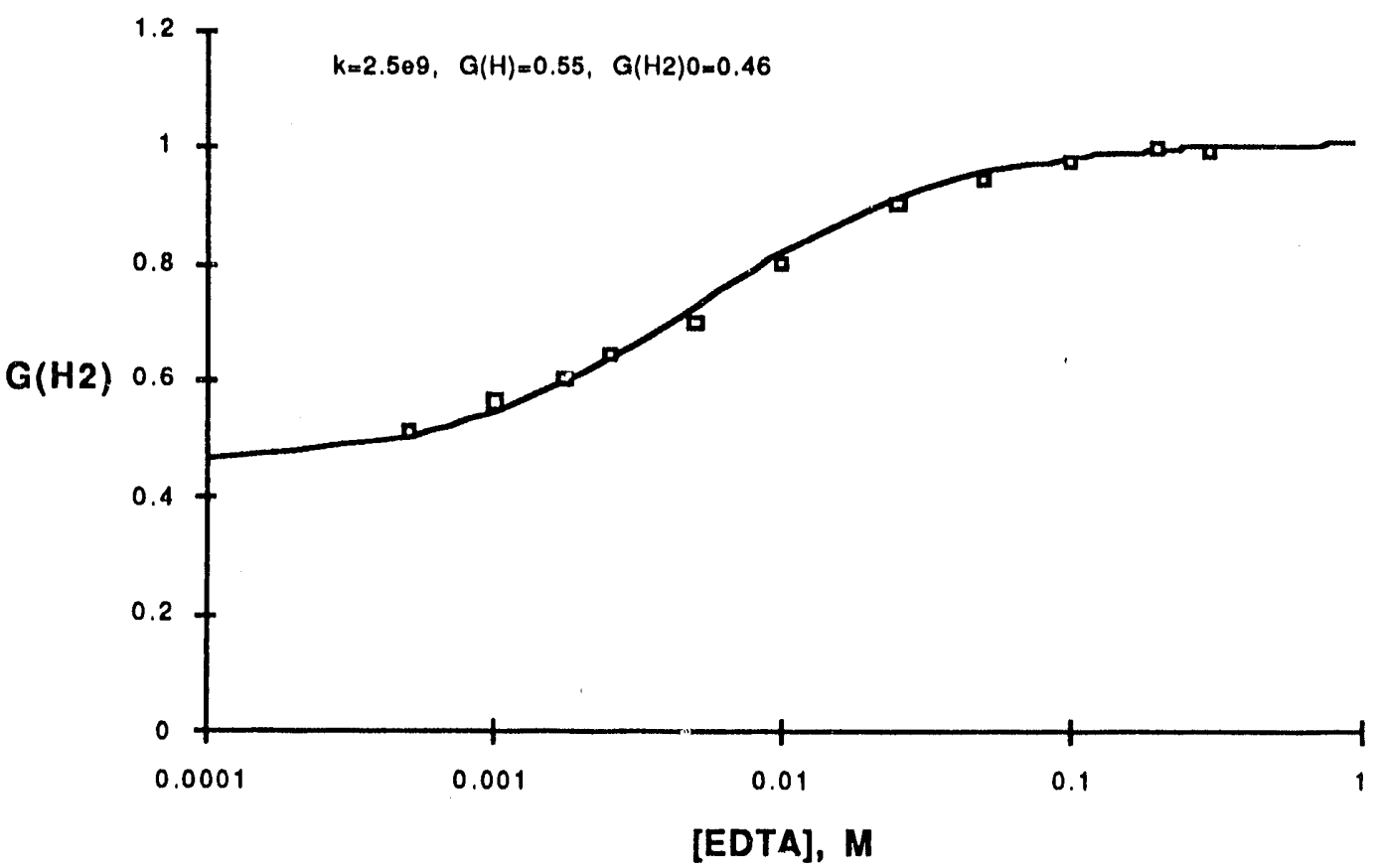

Figure 20. $\mathrm{G}\left(\mathrm{H}_{2}\right)$ at $60^{\circ} \mathrm{C}$ vs. [EDTA] is aqueous $0.1 \mathrm{M} \mathrm{NaOH}, 1 \mathrm{M} \mathrm{NaCl}, 1.0 \mathrm{mM} \mathrm{NaNO} 3$ solution. 


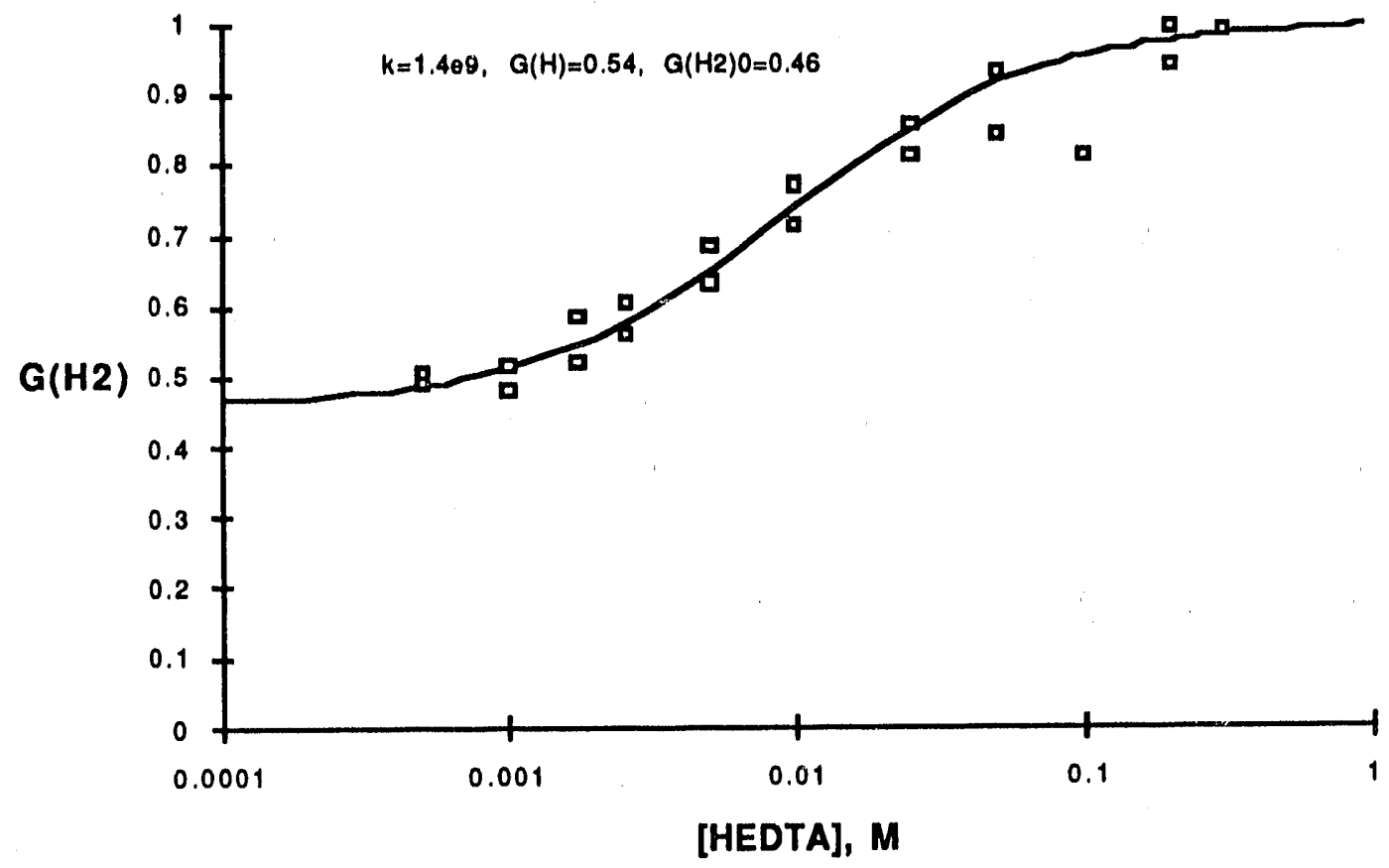

Figure 21. $\mathrm{G}\left(\mathrm{H}_{2}\right)$ at $60^{\circ} \mathrm{C}$ vs. [HEDTA] in aqueous $0.1 \mathrm{M} \mathrm{NaOH}, 1 \mathrm{M} \mathrm{NaCl}, 1.0 \mathrm{mM} \mathrm{NaNO}_{3}$ solution.

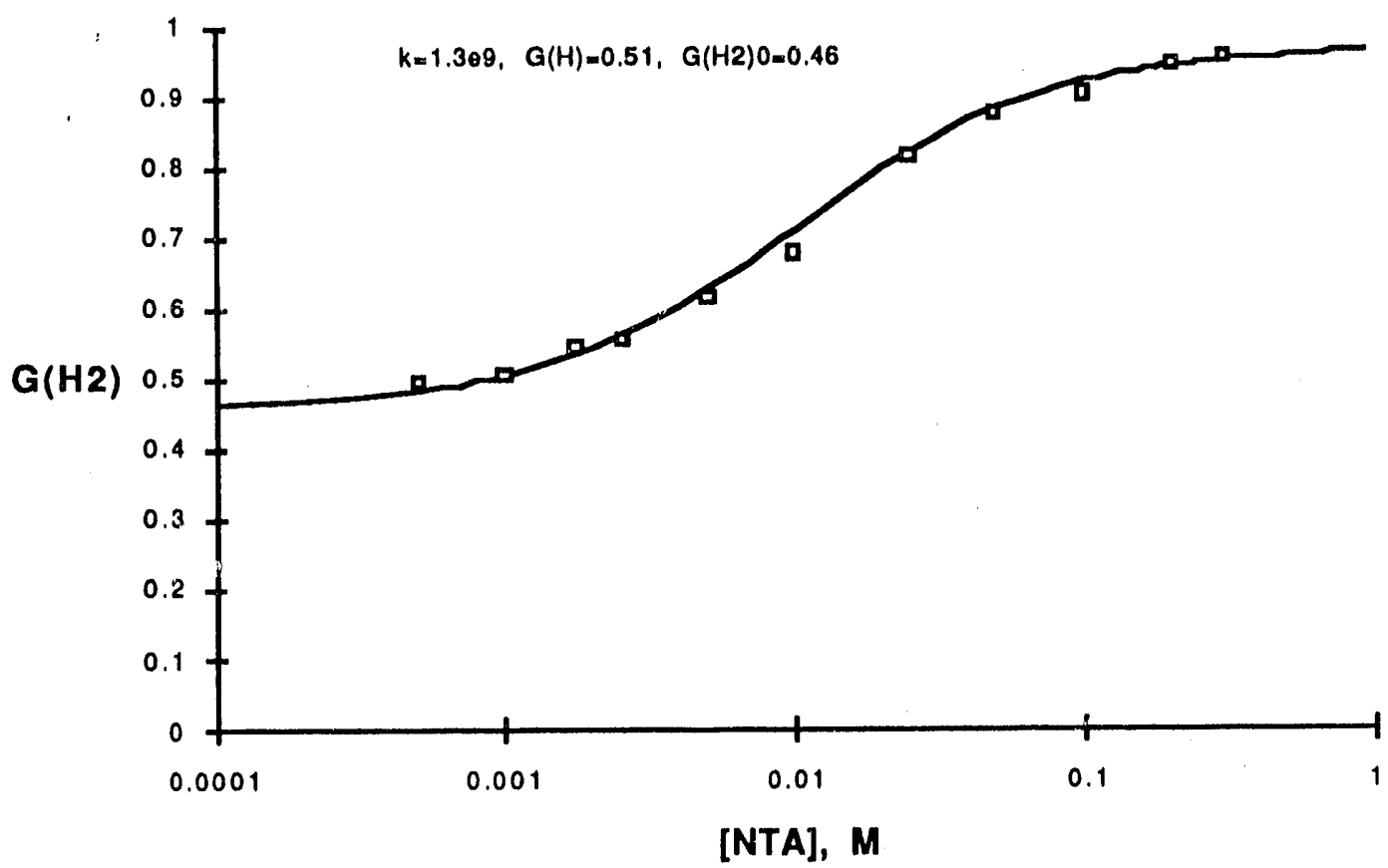

Figure 22. $\mathrm{G}\left(\mathrm{H}_{2}\right)$ at $60^{\circ} \mathrm{C}$ vs. [NTA] in aqueous $0.1 \mathrm{M} \mathrm{NaOH}, 1 \mathrm{M} \mathrm{NaCl}, 1.0 \mathrm{mM} \mathrm{NaNO}_{3}$ solution. 
22

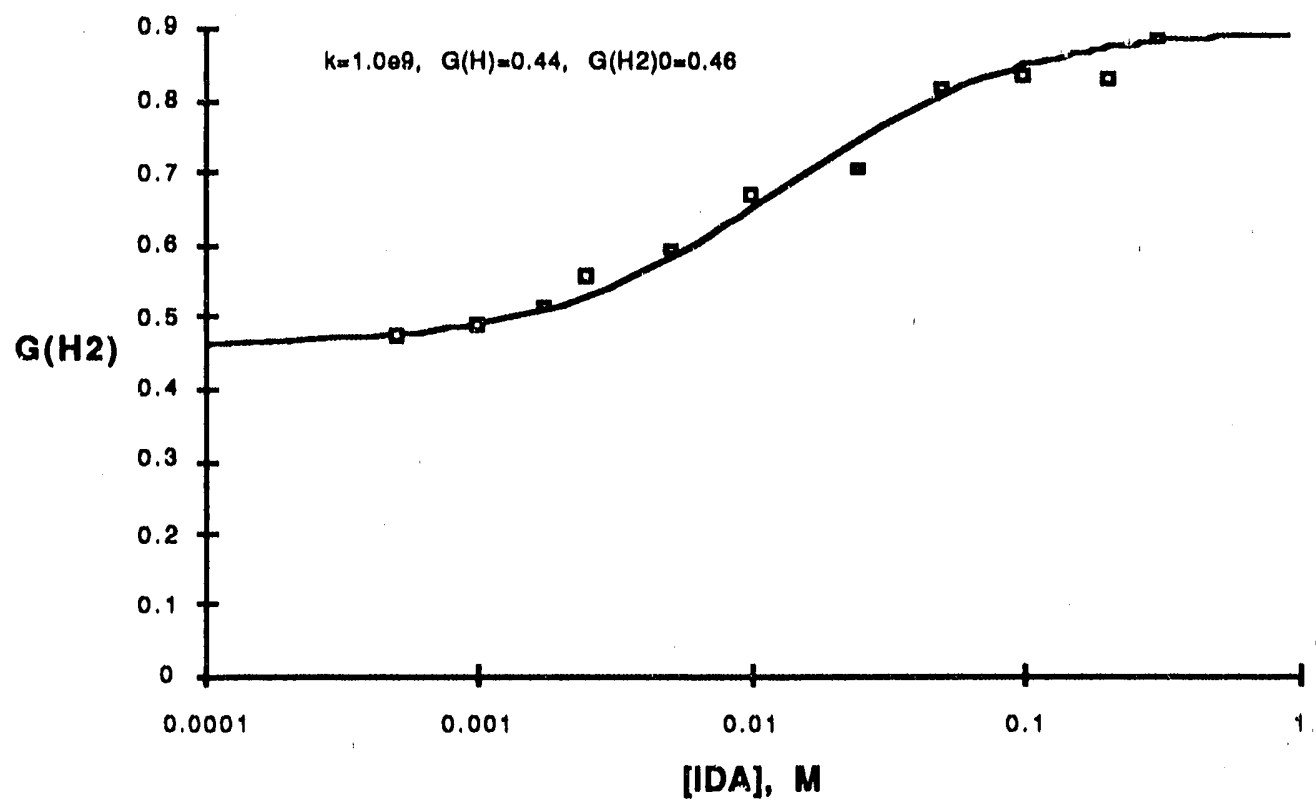

Figure 23. $\mathrm{G}\left(\mathrm{H}_{2}\right)$ at $60^{\circ} \mathrm{C}$ vs. [IDA] in aqueous $0.1 \mathrm{M} \mathrm{NaOH}, 1 \mathrm{M} \mathrm{NaCl}, 1.0 \mathrm{mM} \mathrm{NaNO} 3$ solution.

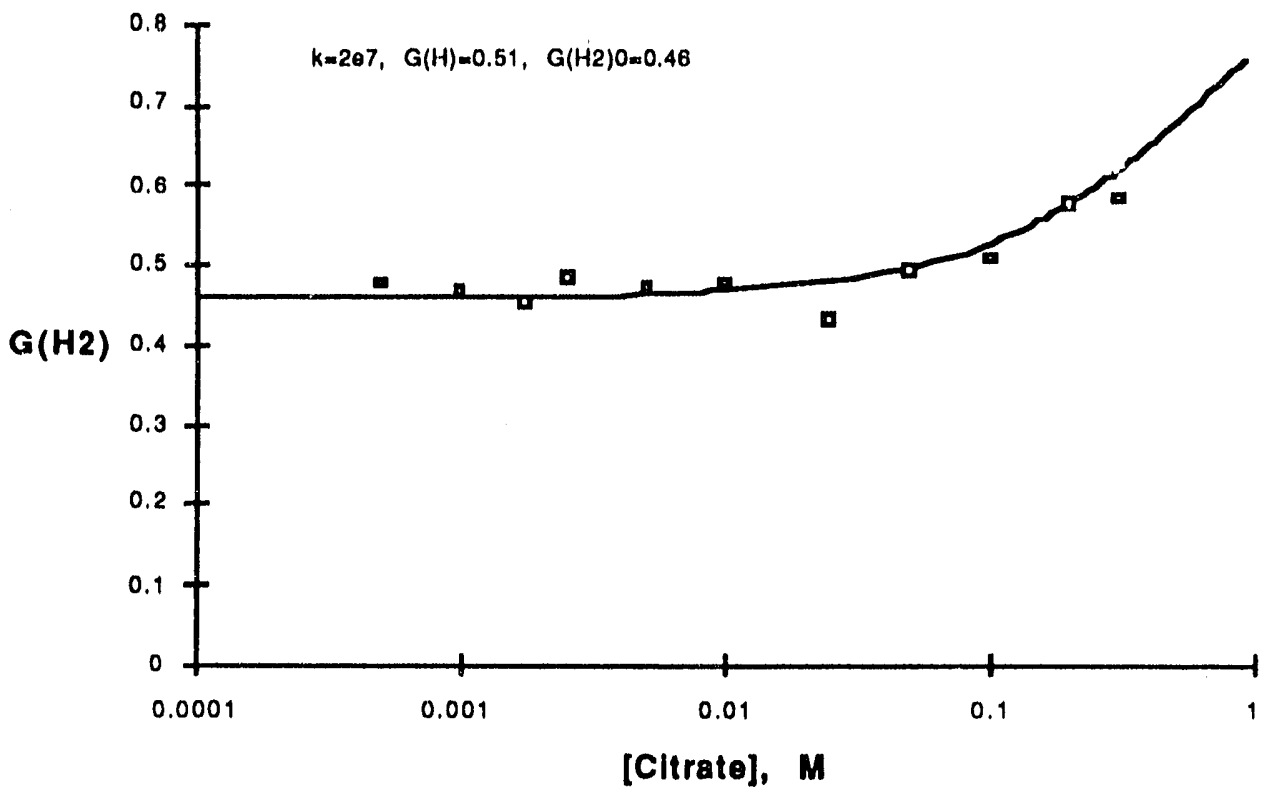

Figure 24. $\mathrm{G}\left(\mathrm{H}_{2}\right)$ at $60^{\circ} \mathrm{C}$ vs. [citrate] in aqueous $0.1 \mathrm{M} \mathrm{NaOH}, 1 \mathrm{M} \mathrm{NaCl}, 1.0 \mathrm{mM} \mathrm{NaNO}$ solution. 
$G(H)$ in equation $I$ is the yield of $H$ atoms that is available to react in the above reactions; it should be the same for all solutions used at a given temperature. In other words, the plateau value of $\mathrm{G}\left(\mathrm{H}_{2}\right)$ seen in Figs. 15-24 should be the same for all solutions because it equals $\mathrm{G}\left(\mathrm{H}_{2}\right)^{0}+$ $\mathrm{G}(\mathrm{H})$. However, if the reaction of $\mathrm{H}$ with $\mathrm{RH}$ can yield products other than $\mathrm{H}_{2}$ (perhaps by addition to $\mathrm{C}=\mathrm{O}$ groups), the observed value will decrease. The experimental results can be fit fairly well using fixed values of $\mathrm{G}(\mathrm{H})$, but the fit was improved by allowing $\mathrm{G}(\mathrm{H})$ to be a variable parameter. The differences in values of $\mathrm{k}_{1}$ obtained by the two methods of fitting are shown in Table 5. From the literature on water radiolysis, one expects a value of $\mathrm{G}(\mathrm{H})$ of $\cong 0.6$ at $25^{\circ} \mathrm{C}{ }^{1}$ slightly higher than the values in Table 5. Model calculations, however, show that $0.1 \mathrm{M} \mathrm{OH}^{-}$will cause an approximately $20 \%$ decrease in this value because of the reaction of $\mathrm{OH}^{-}$with $\mathrm{H}^{+}$in the spur; the proton would have otherwise reacted with eaq to produce $\mathrm{H}$ atoms. Because the values of $\mathrm{G}(\mathrm{H})$ in Table 5 are thus predictable, one may conclude that contributions of reactions of $\mathrm{H}$ atoms with the organic solute that do not produce $\mathrm{H}_{2}$ are small. The apparent variability of $\mathrm{G}(\mathrm{H})$ may be due to experimental imprecision in the $\mathrm{G}\left(\mathrm{H}_{2}\right)$ values shown in Figs. 15-24. However, it is clear that this uncertainty in $\mathrm{G}(\mathrm{H})$ causes a variation in the value of $\mathrm{k}_{1}$ of only 10 to $20 \%$. The recommended values of $\mathrm{k}_{1}$ derived from a consideration of the results in Table 5 are shown in Table 6. Except for citrate, where the increase in $\mathrm{G}\left(\mathrm{H}_{2}\right)$ is too small to obtain a reliable rate constant (or $\mathrm{G}(\mathrm{H}))$, the values of $\mathrm{k}_{1}$ in Table 6 are estimated to be accurate within $\pm 20-30 \%$. This corresponds to tests where least-squares fitting of the data to equation I were done, allowing $\mathrm{G}(\mathrm{H})$ to be a variable, where $95 \%$ confidence-level values of $\pm 20-30 \%$ in $\mathrm{k}_{1}$ were typical.

The rate constants in Table 6 are considerably higher than expected on the basis of those given in our literature survey. ${ }^{1}$ The literature values for EDTA, NTA, IDA, and citric acid at room temperature and $\mathrm{pH} 1$ are also quoted in Table 6. It seems, therefore, that the high-base concentration, which leads to complete ionization of all the carboxylic groups, causes more than an order of magnitude increase in $\mathrm{k}_{1}$. We can only speculate at present that this difference in rate constants between the ionized and protonated forms is a reflection of the electrophilicity of $\mathrm{H}$ atoms. The values obtained at $\mathrm{pH} 13$ are the pertinent ones with respect to understanding the overall mechanism of $\mathrm{H}_{2}$ production in tank 101-SY, where the carboxylic acid groups are likewise completely ionized.

Included in Table 6 are approximate activation energies for the corresponding rate constants. These activation energies should be taken only as a rough approximation sirice they were calculated from measurements at only two temperatures. It has not been verified that the rate constants follow an Arrhenius dependence on temperature.

Table 5. Effect of $\mathrm{G}(\mathrm{H})$ on $\mathrm{k}_{1}$ (in $\left.\mathrm{M}^{-1} \mathrm{~s}^{-1}\right)$. Two methods were used: $\mathrm{G}(\mathrm{H})$ at a fixed value and $\mathrm{G}(\mathrm{H})$ as a variable parameter.

\begin{tabular}{lcccc}
\hline $\begin{array}{l}10^{-9} \times \mathrm{k}_{1} \\
\text { Organic }\end{array}$ & $\begin{array}{c}10^{-9} \times \mathrm{k}_{1} \\
\text { at } 30^{\circ} \mathrm{C} ;\end{array}$ & $\begin{array}{c}\text { at } 30^{\circ} \mathrm{C}_{;} \\
\text {best fit } \\
\mathrm{G}(\mathrm{H})=0.47\end{array}$ & $\begin{array}{c}10^{-9} \times \mathrm{k}_{1} \\
\text { at } 60{ }^{\circ} \mathrm{C}, \\
\text { assumed: } \\
\mathrm{G}(\mathrm{H})=0.51\end{array}$ & $\begin{array}{c}10^{-9} \times \mathrm{k}_{1} \\
\text { at } 60^{\circ} \mathrm{C}_{;} \\
\text {best fit } \\
\mathrm{G}(\mathrm{H}) \text { in } \\
\text { parentheses }\end{array}$ \\
\hline EDTA & 1.3 & $1.1(0.49)$ & 3.0 & 2.5 in parentheses \\
HEDTA & 1.5 & $1.3(0.50)$ & 1.7 & $1.4(0.54)$ \\
NTA & 0.5 & $0.7(0.425)$ & 1.3 & $1.3(0.51)$ \\
IDA & 0.5 & $0.6(0.43)$ & 0.7 & $1.0(0.44)$ \\
Glycolate & & & 1.4 & $0.14(0.50)$ \\
Citrate & $\approx 0.008$ & $\approx 0.005(0.40)$ & $\approx 0.02$ & $\approx 0.02(0.51)$ \\
\hline
\end{tabular}


Table 6. Rate constants for $\mathrm{H}+\mathrm{RH} \rightarrow \mathrm{H}_{2}+\mathrm{R}$.

\begin{tabular}{|c|c|c|c|c|}
\hline RH & $\begin{array}{l}\mathrm{O}^{-9} \times \mathrm{k}_{1} \\
\text { at } 30 \circ \mathrm{O} \\
\mathrm{M}^{-1} \mathrm{~s}^{-1}\end{array}$ & $\begin{array}{c}10^{-9} \times \mathrm{k}_{1} \\
\text { at } 600^{\circ} \mathrm{C} \\
\mathrm{M}^{-1} \mathrm{~s}^{-1}\end{array}$ & $\underset{\text { kcal M-1 }}{\mathrm{Ea}}$ & $\begin{array}{c}10^{-9} \times \mathrm{k}_{1} \\
\text { at } 25 \circ \mathrm{O} \\
\text { and at } \mathrm{pH} 1 \\
\text { (literature value) }\end{array}$ \\
\hline EDTA & 1.2 & 2.7 & 5.4 & 0.065 \\
\hline HEDTA & 1.4 & 1.6 & 0.9 & \\
\hline NTA & 0.6 & 1.3 & 5.2 & 0.0075 \\
\hline IDA & 0.55 & 0.85 & 2.9 & 0.00040 \\
\hline Glycolate & & 0.14 & & \\
\hline Citrate & $\approx 0.007$ & $\approx 0.02$ & 7.1 & 0.00043 \\
\hline $\mathrm{OH}^{-a}$ & 0.033 & 0.13 & 9.2 & \\
\hline
\end{tabular}

${ }^{a}$ All reaction rate constants in the table were measured against these literature values of $k_{2}$.

Finally, we turn to the mechanistic question of the reaction responsible for the effect of the organic solutes on $\mathrm{G}\left(\mathrm{H}_{2}\right)$. If the presence of the organics in Solution $\mathrm{P}$ causes an increase in the $\mathrm{H}_{2}$ yield because of the hydrogen abstraction reaction 1, the values of the rate constants, $\mathrm{k}_{1}$, at 30 and $60^{\circ} \mathrm{C}$ should correlate with the empirical parameter, $R$, which we have defined as the slope of a plot of $\mathrm{G}\left(\mathrm{H}_{2}\right)$ vs. [RH] in Solution P. A comparison is shown in Fig. 25, where $\mathrm{R}$ is plotted vs. $k_{1}$. As can be seen, a good correlation between $R$ and $k_{1}$ is observed. Taken together with the known reactions of all other primary radicals from the radiolysis of water, the good correlation in Fig. 25 is a strong indication that the mechanism proposed to explain the effect of organic additives on $\mathrm{G}\left(\mathrm{H}_{2}\right)$ is correct.

iii. Radiolytic Generation of $\mathrm{N}_{2} \mathrm{O}$. In Solution $\mathrm{P}$, no $\mathrm{N}_{2} \mathrm{O}$ was detected from irradiated samples unless an organic solute was present. The generation of $\mathrm{N}_{2} \mathrm{O}$ in Solution $\mathrm{P}$ containing organic solutes seems to follow a much more complex mechanism than the one for $\mathrm{H}_{2}$ generation. For $30^{\circ} \mathrm{C}$ irradiations, pronounced effects of dose rate (intensity of radiation source) on $\mathrm{G}\left(\mathrm{N}_{2} \mathrm{O}\right.$ ) were observed. Furthermore, $\mathrm{N}_{2} \mathrm{O}$ formation persisted from some samples after the irradiation had been terminated (postirradiation effect). Table 7 summarizes our results on $\mathrm{G}\left(\mathrm{N}_{2} \mathrm{O}\right)$ at different concentrations of the organic solutes and at different doses and dose rates. Reproducibility of the $\mathrm{G}\left(\mathrm{N}_{2} \mathrm{O}\right)$ determinations is $\pm 20 \%$. Whenever postirradiation production of $\mathrm{N}_{2} \mathrm{O}$ was observed, the $\mathrm{G}$ values reported are values obtained from the plateau of the post-irradiation production of $\mathrm{N}_{2} \mathrm{O}$, or from extrapolation to long times based on measured constants for the postirradiation effect.

Except for IDA, the postirradiation effect was not reproducible, and the source for the nonreproducibility is not well understood. In the case of IDA in Solution P when irradiated at $30^{\circ} \mathrm{C}$, the effect was reproducible, and typical postirradiation production of $\mathrm{N}_{2} \mathrm{O}$ is shown in Fig. 26. Figure 26 also shows the effect of radiation dose rate; the production of $\mathrm{N}_{2} \mathrm{O}$ is smaller at the higher dose rate. Similar dependence on dose rate can be deduced from results for the other chelators given in Table 7. For irradiations at $60^{\circ} \mathrm{C}$, no postirradiation production of $\mathrm{N}_{2} \mathrm{O}$ was observed for any of the organic solutes. Presumably, this means that the slow reactions producing $\mathrm{N}_{2} \mathrm{O}$ are markedly accelerated at $60^{\circ} \mathrm{C}$. It can also be seen in Table 7 that for irradiations at $60^{\circ} \mathrm{C}$ no effect of dose rate was observed for IDA in Solution $\mathrm{P}$.

The effect of dose rate on $\mathrm{G}\left(\mathrm{N}_{2} \mathrm{O}\right)$ when irradiated at $30^{\circ} \mathrm{C}$ suggests that a precursor to $\mathrm{N}_{2} \mathrm{O}$ has two competing pathways. One is the pathway that leads to the formation of $\mathrm{N}_{2} \mathrm{O}$ and involves only one precursor molecule (or radical). The other pathway does not lead to the production of $\mathrm{N}_{2} \mathrm{O}$ and involves two radiation-produced species (the two might be identical species). At present 
we do not attempt to attach chemical identity to these precursors. The absence of the dose-rate effect at $60^{\circ} \mathrm{C}$ requires that the pathway involving two radiation-produced species is unimportant at that temperature, and the pathway that involves only one precursor and leads to $\mathrm{N}_{2} \mathrm{O}$ dominates. The temperature dependence implies that the latter pathway has a higher energy of activation than the former.

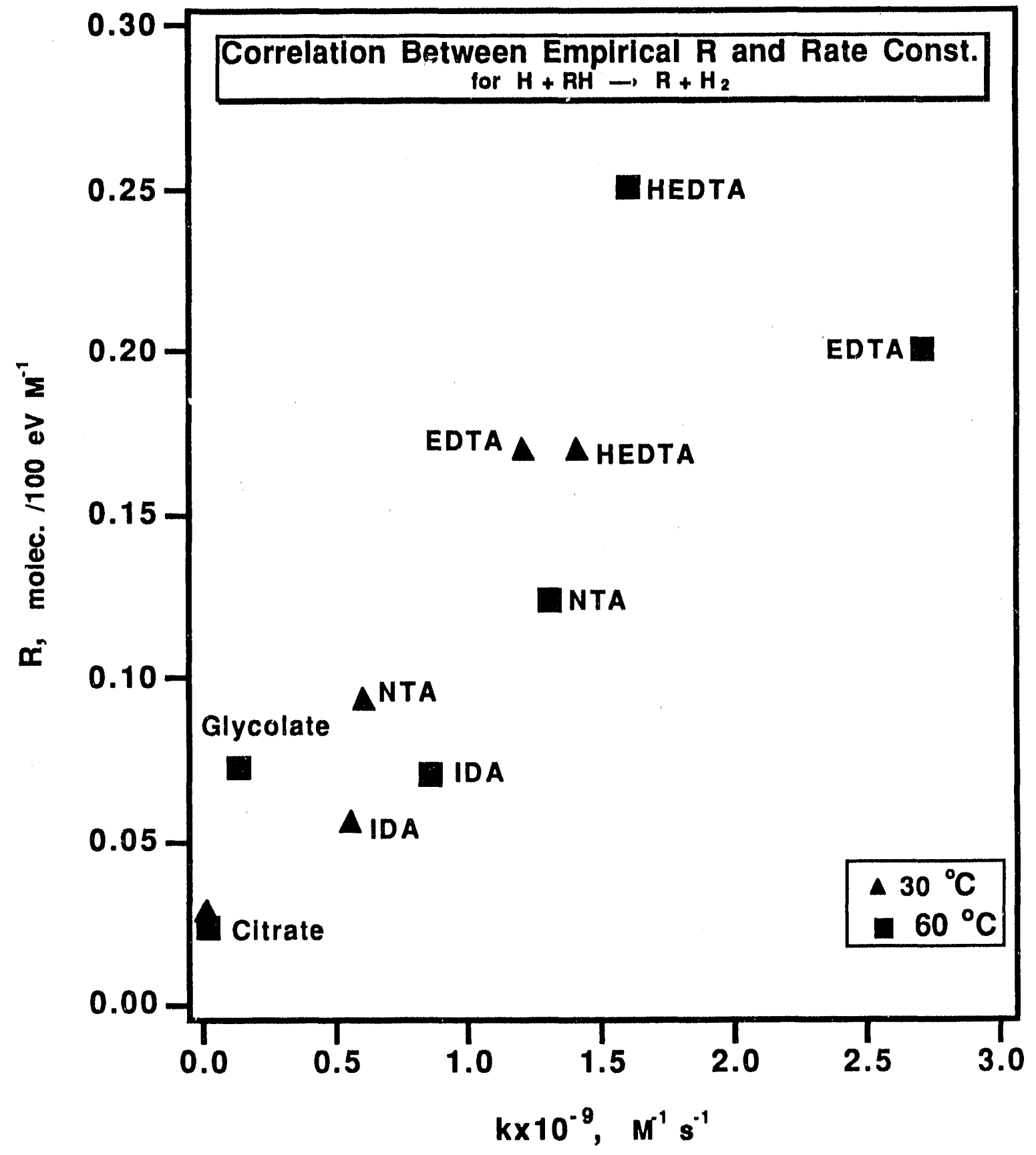

Figure 25. The correlation between the empirical parameter $\mathrm{R}$ and the rate constant $\mathrm{k}$ for $\mathrm{H}$ abstraction. 
Table 7. $\mathrm{G}\left(\mathrm{N}_{2} \mathrm{O}\right)$ for Solution $P$ with the organic solutes under various conditions (irradiations at $30^{\circ} \mathrm{C}$ except where noted).

\begin{tabular}{|c|c|c|c|c|c|c|}
\hline \multirow[b]{2}{*}{ Solute } & \multirow[b]{2}{*}{$\begin{array}{l}\operatorname{dose} \\
\text { (krad) }\end{array}$} & \multirow[b]{2}{*}{$\begin{array}{l}\text { krad/ } \\
\text { min }\end{array}$} & \multicolumn{3}{|c|}{$\mathbf{G}\left(\mathrm{N}_{2} \mathrm{O}\right)$ at the concentration of organic shown } & \multirow[b]{2}{*}{$\begin{array}{l}0.34 \\
\mathrm{M}\end{array}$} \\
\hline & & & $\begin{array}{c}0.0425 \\
M\end{array}$ & $\begin{array}{c}0.085 \\
M\end{array}$ & $\dot{\mathrm{M}}^{0.17}$ & \\
\hline NTA & 120 & 4.4 & & & 0.56 & \\
\hline \multirow[t]{2}{*}{ IDA } & 80 & $\overline{17}$ & & 0.50 & 0.63 & 0.55 \\
\hline & $\begin{array}{l}120 \\
478\end{array}$ & $\begin{array}{l}4.4 \\
4.4\end{array}$ & & & $\begin{array}{c}>0.71 * 0.9 \\
0.71,0.67 \\
0.79\end{array}$ & 0.68 \\
\hline \multirow[t]{2}{*}{$\begin{array}{l}\text { IDA } \\
\text { at } 60^{\circ} \mathrm{C}\end{array}$} & 68 & 4.5 & & & $\begin{array}{c}0.70,0.75 \\
0.63\end{array}$ & \\
\hline & 68 & 0.45 & & & $\begin{array}{c}0.61,0.82, \\
0.79\end{array}$ & \\
\hline Citrate & 120 & $\overline{4.4}$ & & not detected & 0.045 & \\
\hline Glycolate & $\overline{120}$ & 4.4 & & & & $\begin{array}{c}0.42 \\
\text { (at } 0.3 \mathrm{M} \text { ) }\end{array}$ \\
\hline Glycine & $\begin{array}{l}120 \\
500\end{array}$ & $\begin{array}{l}4.4 \\
4.4\end{array}$ & & $\begin{array}{c}0.04 \\
\text { (at } 0.1 \mathrm{M} \text { ) }\end{array}$ & & $\begin{array}{c}0.15 \\
0.75 \\
\text { (at } 0.3 \mathrm{M} \text { ) }\end{array}$ \\
\hline \multirow[b]{2}{*}{ EDTA } & 80 & 17 & & $0.46,0.34$ & & \\
\hline & $\begin{array}{l}121 \\
370 \\
500\end{array}$ & $\begin{array}{l}4.4 \\
4.4 \\
4.4\end{array}$ & 0.63 & $\begin{array}{c}0.54,0.65 \\
0.82 \\
0.75\end{array}$ & 0.50 & \\
\hline \multirow[t]{3}{*}{$\begin{array}{l}\text { EDTA } \\
\text { at } 60^{\circ} \mathrm{C}\end{array}$} & $\begin{array}{l}500 \\
125 \\
125\end{array}$ & $\begin{array}{l}4.5 \\
4.5 \\
4.5\end{array}$ & $\begin{array}{l}0.92 \\
1.03 \\
0.84\end{array}$ & $\begin{array}{l}1.19,1.20,1.25 \\
1.06,1.10,0.97 \\
0.92\end{array}$ & $\begin{array}{c}0.68,0.79 \\
0.85,0.98\end{array}$ & \\
\hline & 94 & 0.55 & & 0.83 & & \\
\hline & 167 & 0.18 & & 1.04 & & \\
\hline \multirow{4}{*}{ HEDTA } & 80 & 17 & & $\overline{0.23}$ & & \\
\hline & 120 & 4.4 & 0.48 & $0.49,0.49,0.52$ & 0.29 & \\
\hline & 94 & 0.55 & & 0.78 & & \\
\hline & 167 & 0.18 & & 1.09 & & \\
\hline \multirow{5}{*}{$\begin{array}{l}\text { EDTA+ } \\
\text { HEDTA }\end{array}$} & 90 & 17 & & 0.33 & & \\
\hline & 120 & 4.4 & 0.7 & $>0.5^{*}, 0.57,0.72 \uparrow$ & 0.50 & \\
\hline & 360 & 4.4 & & $>0.55^{*}$ & & \\
\hline & 96 & 0.55 & & $>0.9^{*},>0.92^{*}$ & & \\
\hline & 160 & 0.18 & & 1.18 & & \\
\hline
\end{tabular}

*Plateau value estimated.

$\uparrow$ Air-saturated solution.

** Concentrations are for each, EDTA and HEDTA. 


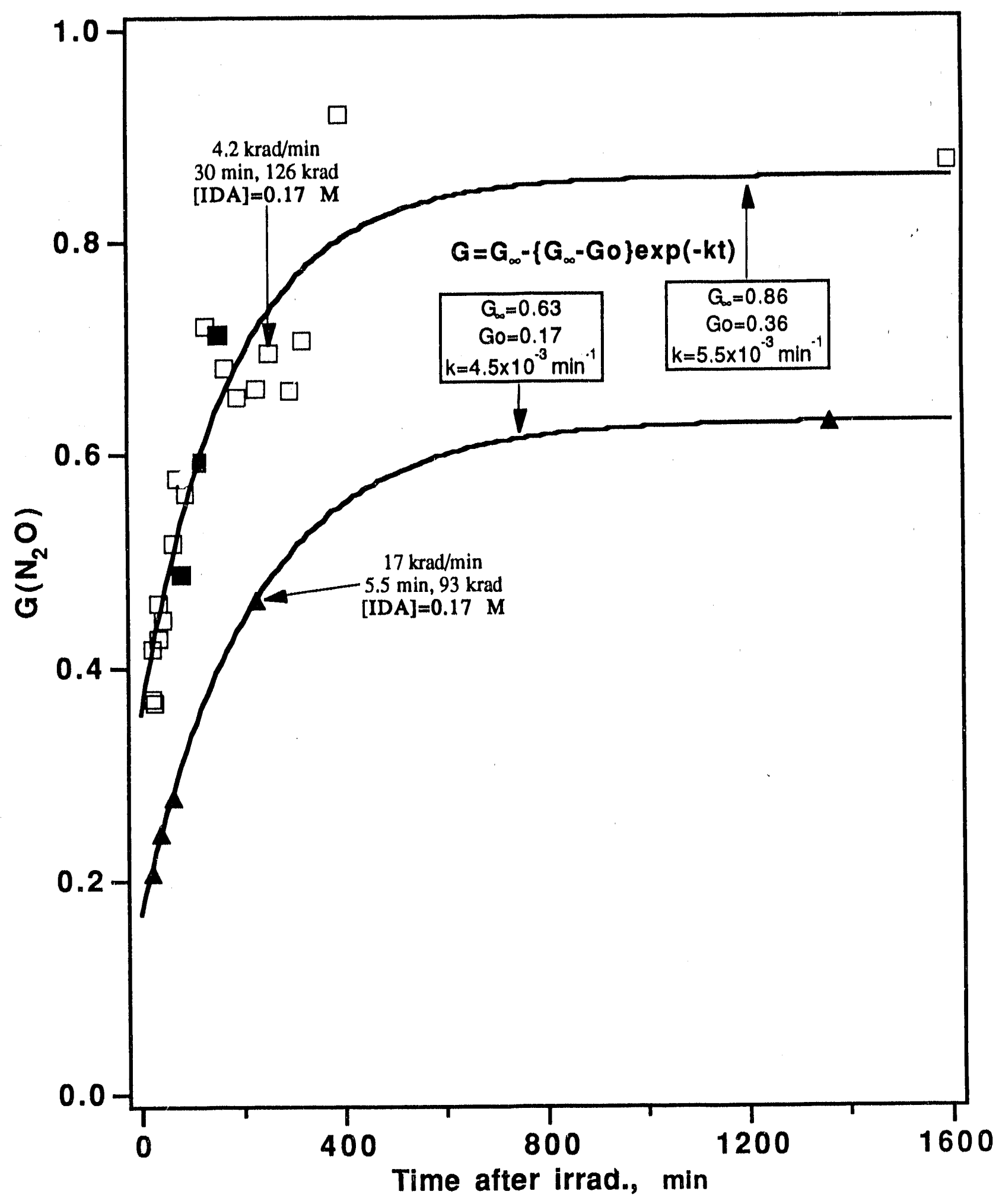

Figure 26. Postirradiation production of $\mathrm{N}_{2} \mathrm{O}$ in $0.17 \mathrm{M}$ IDA in Solution $\mathrm{P}$, at $30^{\circ} \mathrm{C}$. Curves are fits to exponential growth using the equation and parameters shown. 
For some of the organic solutes, an effect of total dose is also observed (this effect is most pronounced for glycine). At the highest dose measured for glycine ( $500 \mathrm{krad})$, and even with a very high $\mathrm{G}$ value for destruction of glycine (for example, $\mathrm{G}(-$ glycine) $=10$ ) only $5 \mathrm{mM}(-1.5 \%)$ of the initial glycine concentration would be consumed. This effect, thus, is not a result of depletion of the original organic solute. Rather, a precursor to $\mathrm{N}_{2} \mathrm{O}$ builds up to some high steady-state level before appreciable production of $\mathrm{N}_{2} \mathrm{O}$ is obtained.

Table $8 \mathrm{c}$ mpares the results on $\mathrm{N}_{2} \mathrm{O}$ yields at 30 and $60^{\circ} \mathrm{C}$ for a limited set of conditions of organic solute concentration, dose, and dose rate. The yield of $\mathrm{N}_{2} \mathrm{O}$ in most cases is higher at 60 'C. Because determinations of $\mathrm{N}_{2} \mathrm{O}$ yields are less reproducible than the $\mathrm{H}_{2}$ determinations, errors as high as $25 \%$ are possible in the ratios given in Table 8.

Table 8. Comparison of $\mathrm{G}\left(\mathrm{N}_{2} \mathrm{O}\right)$ from irradiation at 30 and $60^{\circ} \mathrm{C}$ of Solution $\mathrm{P}$ containing various additives ${ }^{a}$.

\begin{tabular}{llllc}
\hline Additive & $\begin{array}{c}{[\mathrm{RH}]} \\
\mathrm{M}\end{array}$ & $\begin{array}{c}\mathrm{G}\left(\mathrm{N}_{2} \mathrm{O}\right) \\
\text { at } 60^{\circ} \mathrm{C}\end{array}$ & $\begin{array}{c}\mathrm{G}\left(\mathrm{N}_{2} \mathrm{O}\right) \\
\text { at } 30^{\circ} \mathrm{C}\end{array}$ & $\begin{array}{c}\text { Ratio } \\
\frac{\mathrm{G}_{60}{ }^{\circ} \mathrm{C}}{\mathrm{G}_{30}{ }^{\circ} \mathrm{C}}\end{array}$ \\
\hline None & 0 & 0 & 0 & - \\
EDTA & 0.085 & 1.10 & 0.60 & 1.8 \\
HEDTA & 0.085 & 0.77 & 0.50 & 1.43 \\
NTA & 0.17 & 0.48 & 0.56 & 0.86 \\
IDA & 0.17 & 0.94 & 0.76 & 1.24 \\
Citrate & 0.17 & 0.064 & 0.045 & 1.42 \\
Glycine & 0.3 & 0.47 & 0.15 & 3.1 \\
Glycolate & 0.3 & 0.86 & 0.42 & 2.0 \\
POC & $b$ & 0.87 & 0.49 & 1.8 \\
POI & $c$ & 1.06 & 0.48 & 2.2 \\
\hline
\end{tabular}

${ }^{a}$ All samples received $125 \mathrm{krad}$ in 30 -min irradiations.

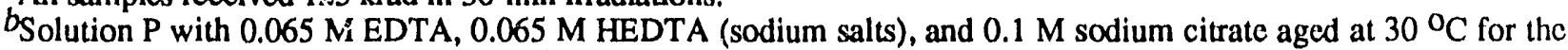
same period of time as solution POI. ${ }^{\mathrm{C}}$

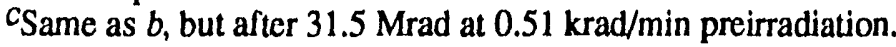

iv. Origin of Nitrogen in $\mathrm{N}_{2} \mathrm{O}$. Experiments with ${ }^{15} \mathrm{~N}$-labeled glycine have been performed to determine what part of $\mathrm{N}$ in $\mathrm{N}_{2} \mathrm{O}$, if any, comes trom the organic solutes. Glycine is utilized here as a representative $\mathrm{N}$-containing organic additive and is a known radiolytic degradation product of the chelators originally placed in the tank. ${ }^{1}{ }^{15} \mathrm{~N}$-labeled glycine was chosen for this experiment because it is readily available commercially at a reasonable cost. Tables 7 and 8 show that $\mathrm{N}_{2} \mathrm{O}$ is produced in Solution $\mathrm{P}$ containing glycine. Samples were $0.3 \mathrm{M}^{15} \mathrm{~N}$ glycine $(98$ atom $\%$ ) in Solution P, irradiated at $30^{\circ} \mathrm{C}$ at $4.5 \mathrm{krad} / \mathrm{min}$ to a dose of $540 \mathrm{krad}$. On the basis of known natural isotopic abundances, irradiation of an unlabeled sample was expected to give a mass/charge 45 to mass/charge 44 ratio of 0.0078 . Values obtained for replicate samples were 0.0076 and 0.0148 for the unlabeled system. Using the labeled glycine, the values of the ratio obtained for replicate samples were 0.0333 and 0.0336 . Assuming no isotope effects in the reactions leading to $\mathrm{N}_{2} \mathrm{O}$ (and such should be small), these results indicate that less than $2.6 \%$ of the $\mathrm{N}_{2} \mathrm{O}$ molecules formed contain a $\mathrm{N}$ from the glycine. Hence, the nitrogen in the $\mathrm{N}_{2} \mathrm{O}$ must come overwhelmingly from the inorganic ions, $\mathrm{NO}_{2}^{-}$or $\mathrm{NO}_{3}{ }^{-}$. Nonetheless, the organic component is essential for the production of $\mathrm{N}_{2} \mathrm{O}$. The conclusion from the isotopic labeling experiments is in agreement with other observations. $\mathrm{N}_{2} \mathrm{O}$ is produced in irradiated Solution P containing glycolate (Tables 7 and 8 ); as glycolate contains no $\mathrm{N}$, it is clear that the organic nitrogenous moiety is not important. The only other source of nitrogen in the system are the $\mathrm{NO}_{\mathbf{x}}$ - ions. 
v. Radiolytic Generation of Other Gases. Figure 27 shows the $\mathrm{G}$ value of $\mathrm{O}_{2}$ production from Solution $\mathrm{P}$ (no organic additives) at several dose rates. It is clear that the experimental scatter is large (probably due to interference from small air leaks during the analytical procedure), and we can only estimate $\mathrm{G}\left(\mathrm{O}_{2}\right)=0.08 \pm 0.03$ over the intensity range studied. When an organic solute is present in Solution $\mathrm{P}, \mathrm{O}_{2}$ is not observed as a product. In fact, analysis of the gases remaining in irradiated Solution $P$ containing $0.085 \mathrm{M}$ each of EDTA and HEDTA, which were saturated with air prior to the irradiation, showed that $\mathrm{O}_{2}$ was consumed. The value obtained for the destruction of $\mathrm{O}_{2}$ is $\mathrm{G}\left(-\mathrm{O}_{2}\right)=7 \pm 1$. The mechanism for the generation of $\mathrm{O}_{2}$ in highly concentrated nitrate solutions is well established to involve direct absorption of a fraction of the radiation energy by the solute rather than the solvent. This fraction will not significantly change by the addition of the organic components at the concentrations discussed here. Therefore, we believe that the generation of dioxygen in the solutions containing the organic solutes proceeds at the same rate as in their absence. The observation that no oxygen is found, and in fact that oxygen is destroyed, in Solution $\mathbf{P}$ when organic chelators are added must mean, therefore, that an organic intermediate that is produced by the radiolysis destroys $\mathrm{O}_{2}$. Since the yield of $\mathrm{O}_{2}$ destruction is so high, this also means that the majority of the radiolytically produced $\mathrm{NO}_{\mathbf{x}}$ intermediates react with the organic components. Data collected here, or the information available in the literature, are insufficient to identify these intermediates.

Dinitrogen was observed as a product for irradiations at $60^{\circ} \mathrm{C}$, with $\mathrm{G}=0.13$ in Solution POI and $\mathrm{G}=0.07$ in Solution $\mathrm{P}$ containing $0.3 \mathrm{M}$ glycine. It was not found in measurable amounts in any of the other solutions for similar rar' iation doses. Ammonia odor was also clearly sensed from Solution POI after the long-term preirsadiation period. No quantitative information on $\mathrm{NH}_{3}$ generation is available at present.

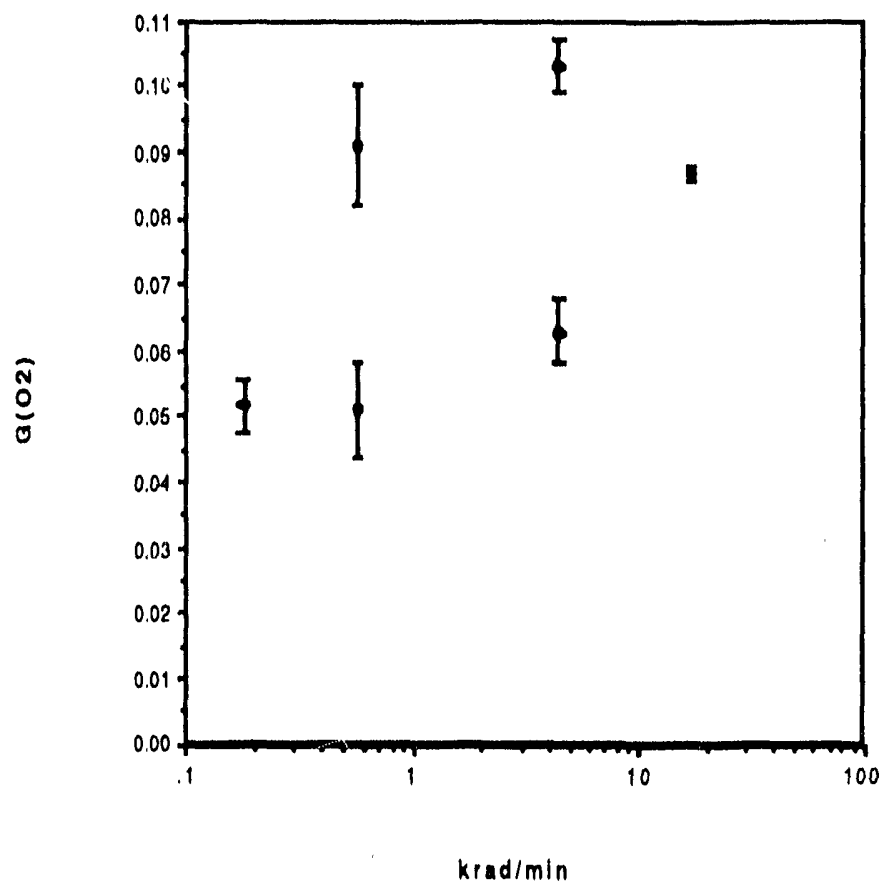

Figure 27. $\mathrm{G}\left(\mathrm{O}_{2}\right)$ vs. dose rate for Solution $\mathrm{P}$. 
vi. Thermal Generation of Gases. A significant result concerning the thermal production of $\mathrm{H}_{2}$ and $\mathrm{N}_{2} \mathrm{O}$ has been obtained in the process of determining the "blanks" for the radiolysis experiments at $60^{\circ} \mathrm{C}$. We have determined the rates of production of these gases without radiolysis. For various organic additives dissolved in Solution $\mathrm{P}$, we find that the rate of thermal generation of $\mathrm{H}_{2}$ and $\mathrm{N}_{2} \mathrm{O}$ is negligible (less than $1 \%$ ) as compared to the rate of the radiolytic generation at the dose rates used in our experiments (significant though when the dose rate in tank 101-SY is taken into account). No thermal gas generation was detected at $30^{\circ} \mathrm{C}$.

However, much higher rates of thermal production of these gases were obtained from the preirradiated Solution POI (Solution P, containing the sodium salts of EDTA $(0.065 \mathrm{M})$, HEDTA $(0.065 \mathrm{M})$, and citrate $(0.1 \mathrm{M})$, which had been irradiated to a dose of $31.5 \mathrm{Mrad}$ at 0.51 $\mathrm{krad} / \mathrm{min})$. This solution was degassed after the preirradiation by bubbling with argon. An identical solution (POC) was not preirradiat a but was otherwise treated identically as a control to check that no changes took place in the solution due to standing for long periods of time. Solution POC was found to produce the gases at a very slow rate, but Solution POI generated $\mathrm{H}_{2}$ at a rate of about $3 \%$ of the radiolytic rate and $\mathrm{N}_{2} \mathrm{O}$ at a rate of about $15 \%$ of the radiolytic rate (compared to $4.5 \mathrm{krad} / \mathrm{min}$ dose rate). The results from the thermal generation of $\mathrm{H}_{2}$ and $\mathrm{N}_{2} \mathrm{O}$ are summarized in Figs. 28 and 29. The rates obtained from these data are summarized in Table 9. An experiment was also conducted on Solution POI where room light was excluded; the results were the same as without exclusion of room light. Thus, photochemical processes are not important in the production of these gases under our experimental conditions.

The results from Solutions POI and POC at $60^{\circ} \mathrm{C}$ show that the preirradiation (solution POI) caused the formation of relatively long-lived products that substantially enhance the thermal production of $\mathrm{H}_{2}$ and $\mathrm{N}_{2} \mathrm{O}$. We have not determined the minimum dose required for the development of these enhanced thermal yields in Solution POI; however, it is certainly less than the dose received by the contents of tank 101-SY. If the contents of tank 101-SY behave similarly to Solution POI, the thermal production of these gases would predominate over the radiolytic production. Using a dose rate in tank 101-SY of $26 \mathrm{rad} / \mathrm{min}$ and $\mathrm{G}$ values of $\mathrm{H}_{2}$ and $\mathrm{N}_{2} \mathrm{O}$ from Solution POI of 0.078 and 0.9 , respectively (based on the $\mathrm{G}$ values given in Table 7 , and corrected for the contribution from thermal production using the results reported here), one obtains $\mathrm{H}_{2}$ and $\mathrm{N}_{2} \mathrm{O}$ production rates by radiolysis of $2.8 \times 10^{-9}$ and $0.33 \times 10^{-7}$ moles liter-1 $\mathrm{min}^{-1}$, respectively. Thus, using the thermal production rates in Table $9,40 \%$ of the $\mathrm{H}_{2}$ and $6 \%$ of the $\mathrm{N}_{2} \mathrm{O}$ would be radiolytically generated in the tank.

Table 9. Rates of thermal $\mathrm{H}_{2}$ and $\mathrm{N}_{2} \mathrm{O}$ generation at $60^{\circ} \mathrm{C}$.

\begin{tabular}{lcc}
\hline Solution & $10^{9} \times \mathrm{H}_{2}$, moles liter $\mathrm{min}^{-1}$ & $10^{7} \times \mathrm{N}_{2} \mathrm{O}$, moles liter $\mathrm{min}^{-1}$ \\
\hline POI & 8.3 & 5.1 \\
POC & 1.2 & 0.2 \\
P with 0.17 M IDA & 1.3 & not detected \\
P with 0.085 M HEDTA & 0.7 & not detected \\
\hline
\end{tabular}




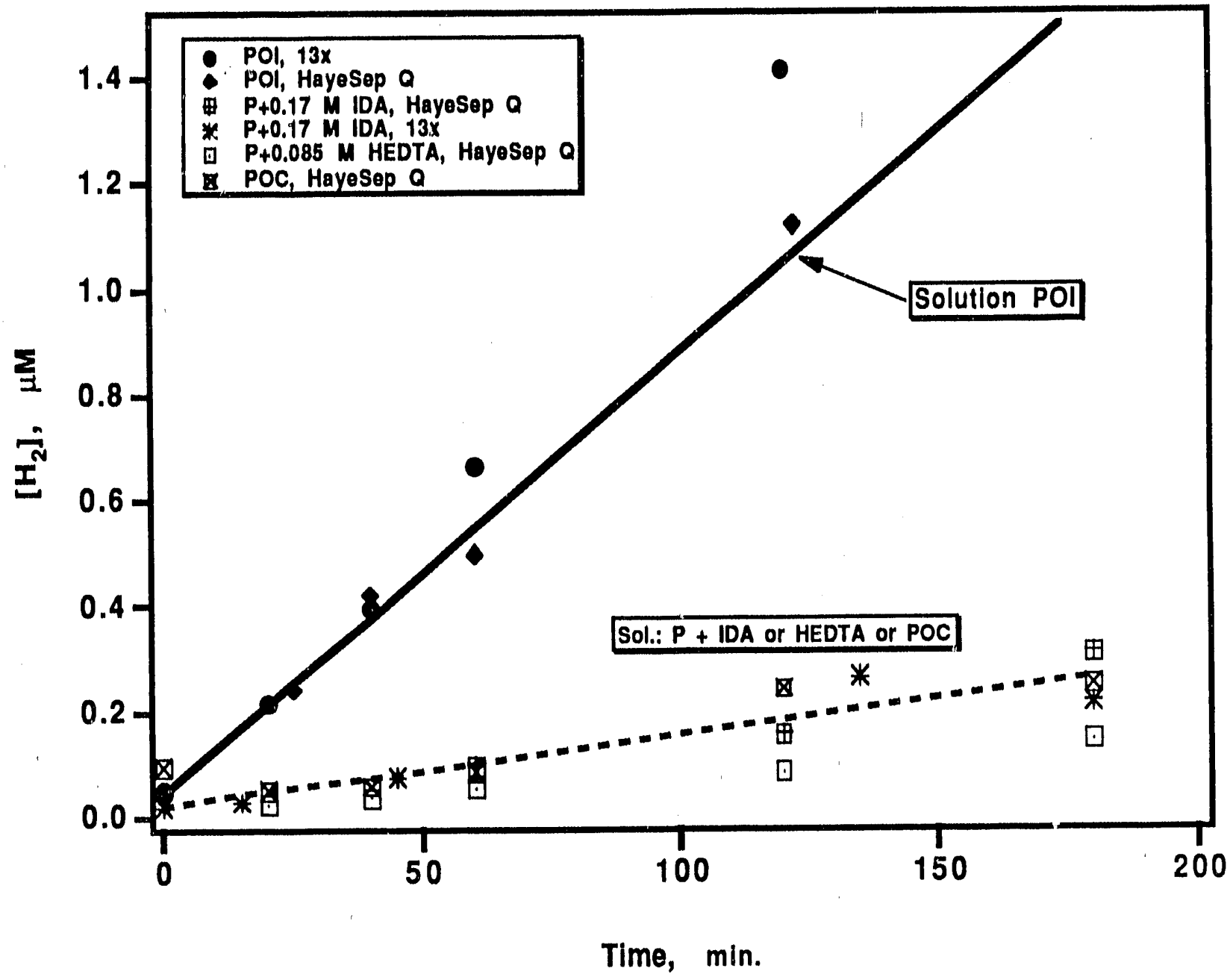

Figure 28. Thermal production of $\mathrm{H}_{2}$ at $60^{\circ} \mathrm{C}$ from several solutions. "HayeSep ${ }^{T M} \mathrm{Q}^{\prime}$ and " $13 \mathrm{x}^{\prime}$ (molecular sieve 13x) refer to the gas chromatographic columns used for aralysis. The lower line is a least-squares fit to one of the IDA data sets. The upper line is a least-squares fit to solution POI, HayeSep ${ }^{T M} \mathrm{Q}$ data set. 


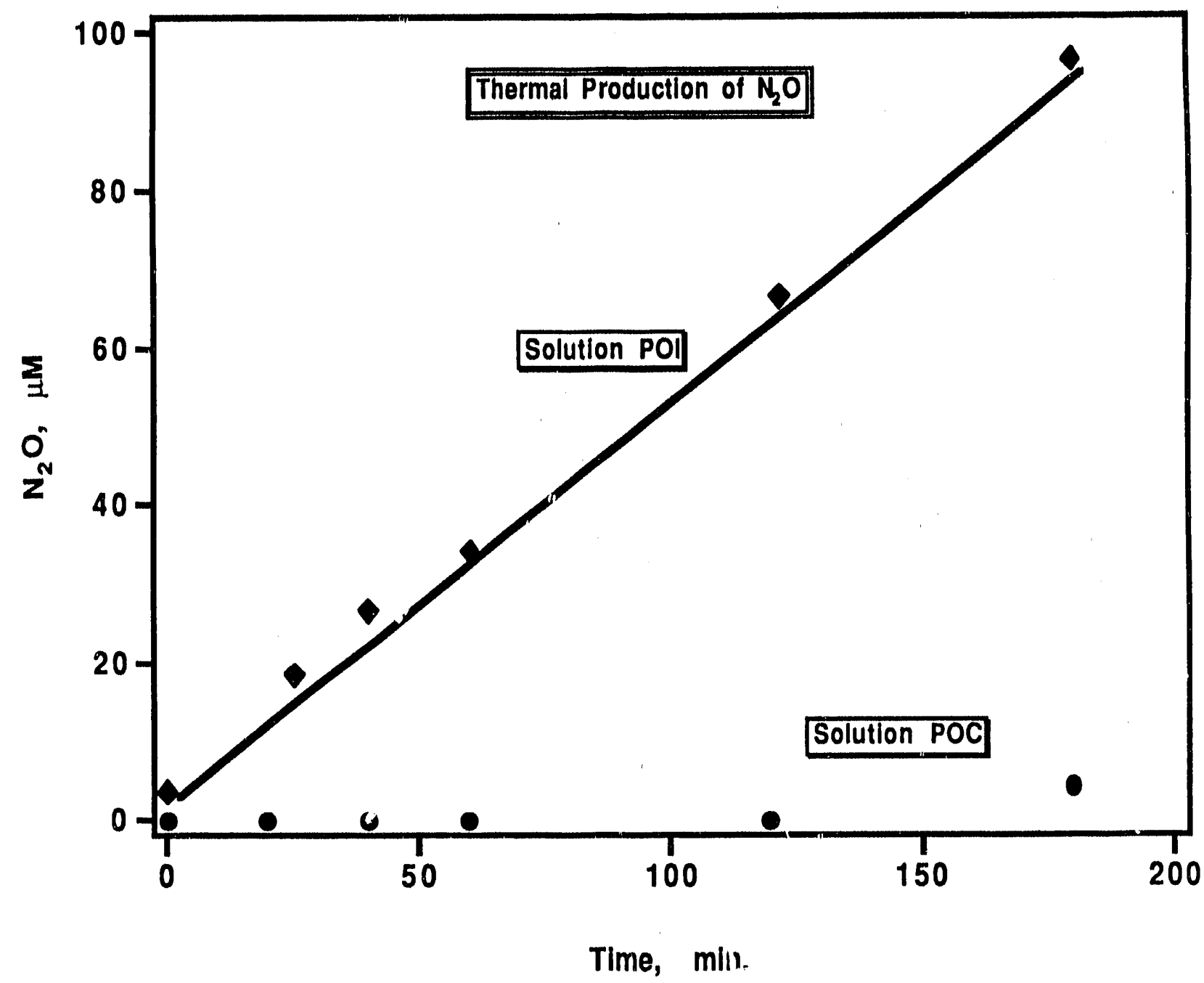

Figure 29. Production of $\mathrm{N}_{2} \mathrm{O}$ at $60^{\circ} \mathrm{C}$ from Solutions POI and POC. The separation and analysis was done with a HayeSep ${ }^{T M} \mathrm{Q}$ column. 


\section{SUBTASK 3: MODELING}

\section{3a. Objectives and Approach}

Because the precise composition of the waste solutions is presently unknown, it is difficult to define a simulated system for experimental studies that will exactly match the tank solution. Although an experimental program that probes the possible range of conditions mig':: 'Je conceivable, it would be time consuming, and an understanding of the underlying mechanisms would not be obtained. This mechanistic understanding will be invaluable if tanks other than 101-SY develop similar risks. Chemical treatment in the future will also raise similar chemical concerns. For these reasons, it was decided to attempt to model the heterogeneous kinetics that can occur in a simulated homogeneous waste system. The calculations were intended to both guide the experimental work and he guided by its results. This dichotomy arises because many nathways are possible and many experiments under various experimental conditions could be done. The theoretical work will provide a framework for understanding the experimental work and suggest tests of the mechanism. The results of the experiments can then be used to refine the parameters and modify the mechanisms that are considered experimentally. The calculations were not intended to quantitatively simulate experimental data collected under subtask 2, nor were they intended to simulate the results of the tank chemistry. Rather, qualitative agreement and identification of trends that may emerge were the goal.

The following questions were addressed by the computational effort: a. What is the mechanism of dihydrogen production in the radiolysis of simulated waste solutions? $b$. How do the concentrations of the various components in the system (nitrate, nitrite, base, and organic) affect the yield of $\mathrm{H}_{2}$ ? c. What are the possible mechanisms for the production of $\mathrm{N}_{2} \mathrm{O}$ in these systems? d. What chemistry can affect the production mechanisms and yields of these two gases? e. How much hydrogen peroxide will be formed radiolytically? The results of the calculations, to be discussed in the following section, address all of these questions. Details of the model used are briefly discussed in Appendix B.

\section{3b. Results}

i. Hydrogen-Production Mechanisms and Yields. There are three dominant radiolytic $\mathrm{H}_{2}$ formation mechanisms in the tank system. One is the fragmentation of a water raolecule that absorbs the radiation energy to form directly $\mathrm{H}_{2}$. This process occurs within a picosecond of the energy absorption event. The actual chemical or physical mechanism by which this takes place is at present unknown. The second mechanism includes recombination reactions between radicals generated by the fragmentation of water molecules. The third mechanism is the production of $\mathrm{H}_{2}$ via the abstraction of a $\mathrm{H}$ atom from an organic molecule by a $\mathrm{H}$ atom that was formed by the fragmentation of water. The major pathways are shown in reactions 1 and 4-7.

$$
\begin{aligned}
& \mathrm{H}_{2} \mathrm{O}^{*} \stackrel{\mathrm{H}_{2} \mathrm{O}^{*}}{\longrightarrow} \mathrm{H}_{2}+2 \mathrm{OH} \\
& \mathrm{e}_{\mathrm{aq}}^{-}+\mathrm{H} \stackrel{\mathrm{H}_{2} \mathrm{O}}{\longrightarrow} \mathrm{H}_{2}+\mathrm{OH}^{-} \\
& \mathrm{e}_{\mathrm{aq}}^{-}+\mathrm{e}_{\mathrm{aq}}^{-} \stackrel{2 \mathrm{H}_{2} \mathrm{O}}{\longrightarrow} \mathrm{H}_{2}+2 \mathrm{OH}^{-} \\
& \mathrm{H}+\mathrm{H} \longrightarrow \mathrm{H}_{2} \\
& \mathrm{H}+\mathrm{RH} \longrightarrow \mathrm{H}_{2}+\mathrm{R}
\end{aligned}
$$


The first mechanism, reaction 4 , is difficult to prevent by any chemical additive. However, as it requires absorption of the radiation by water, the amount of $\mathrm{H}_{2}$ produced by this reaction will be proportional to the electron density of water in the solution (but see also Appendix B). The other two mechanisms, reactions 5-7 and reaction 1, strongly depend on the possible reaction pathways of the $\mathrm{H}$ atom, that is, they will depend on the composition of the solution. In addition to reactions 1 and 4-7, there are other pathways for the disappearance of the $\mathrm{H}$ atom (or $\mathrm{e}_{\mathrm{aq}}$ ) that do not lead to $\mathrm{H}_{2}$. In the waste solutions these are primarily reactions with $\mathrm{OH}$ radicals (only within the spur will this be of importance) and the reaction with $\mathrm{NO}_{2}^{-}$(and $\mathrm{NO}_{3}^{-}$for $\mathrm{e}_{\mathrm{aq}}^{-}$).

Reaction between $\mathrm{H}$ atoms and other water-degradation products of the ionization event will depend on the initial spatial distribution and concentration of the radicals that occur in the ionization. The results in Fig. 30 clearly show that the dependence of $\mathrm{H}_{2}$ yields on the model parameters is minimal. Two greatly different descriptions of the ionization event give essentially identical $\mathrm{H}_{2}$ yields. The yields in Fig. 30 are plotted as a function of the product of the rate constant of the reaction of the $\mathrm{H}$ atom with the organic molecule (reaction 1 ) and the concentration of the organic molecule. Note that this figure uses our original parameters for the yield of the initial radicals and these results would overestimate the $\mathrm{H}_{2}$ yield (see Appendix $\mathrm{B}$ for discussion).

The yield of $\mathrm{H}_{2}$ depends strongly on the concentration of $\mathrm{NO}_{2}^{-}$, as shown in Fig. 31. Furthermore, this figure shows that the yield of $\mathrm{H}_{2}$ is relatively independent of the $\mathrm{NO}_{3}$ concentration in the concentration range examined. Thus, it is clear from these results that it is important to know the concentration of $\mathrm{NO}_{2}^{-}$accurately; conversely, approximate knowledge of the concentration of nitrate will suffice as long as it is above approximately $0.5 \mathrm{M}$. Furthermore, these calculations also show that if the concentration of $\mathrm{NO}_{2}^{-}$in the system is greater than $2 \mathrm{M}$, there is little likelihood that any other $\mathrm{H}$-atom scavenger can decrease the $\mathrm{H}_{2}$ yield substantially. Addition of any other $\mathrm{H}$-atom scavenger is equivalent in that sense to increasing the concentration of $\mathrm{NO}_{2}^{-}$. Since higher nitrite concentration, above the $2 \mathrm{M}$ level, will not decrease the $\mathrm{H}_{2}$ yield, neither would the addition of other scavengers. The nitrate ion is important as a scavenger for $e_{a q}^{-}$(thus minimizing reactions 5 and 6), and it is even more efficient than nitrite in preventing these reactions.

The calculated yields of radiolytically generated $\mathrm{H}_{2}$ as a function of $\mathrm{k} \times[\mathrm{RH}]$ (in units of $\mathrm{sec}^{-1}$ ) are shown in Fig. 32. These yields were obtained from computation of the rate of formation of $\mathrm{H}_{2}$ (similar to Fig. B-1 in Appendix B). Since there are no pathways for $\mathrm{H}_{2}$ destruction, the yields obtained at the end of the reaction are also the final radiolytic yields. The calculations, however, assumed literature values for the rate constants of $\mathrm{H}$ with the organic compounds (measured at low ionic strength and $\mathrm{pH} 1$ ). Our own results show (see Section $2 \mathrm{~b}$-ii above) that the actual rate constants at high $\mathrm{pH}$ are considerably larger. In addition, the calculations of Fig. 32 used considerably higher yields for the radiolytic production of the $\mathrm{H}$ atoms and $\mathrm{H}_{2}$ molecules than is appropriate for the high-concentration system (see Appendix B for the discussion). Figure 33 shows revised calculations using both the revised model parameters and the rate constants measured during this study for reaction 1 of the $\mathrm{H}$ atom with the organic solutes. Also, the same concentrations of inorganic salts that were used in Solution $P$ were used in the calculations of Fig. 33. The results of the calculations shown in Fig. 33 agree with the experimental results to within a factor of two. The trends observed in the experimental results are always the same as those provided by the calculations. The two calculations, those in Fig. 32 and in Fig. 33, are in good agreement. They both show that the yield of $\mathrm{H}_{2}$ is strongly dependent on the identity (rate constant) and concentration of the organic additive. Both figures are shown in order to emphasize that this conclusion does not depend on the precise characteristics of the reaction or on assumptions of the primary radiolysis fragmentation processes. 


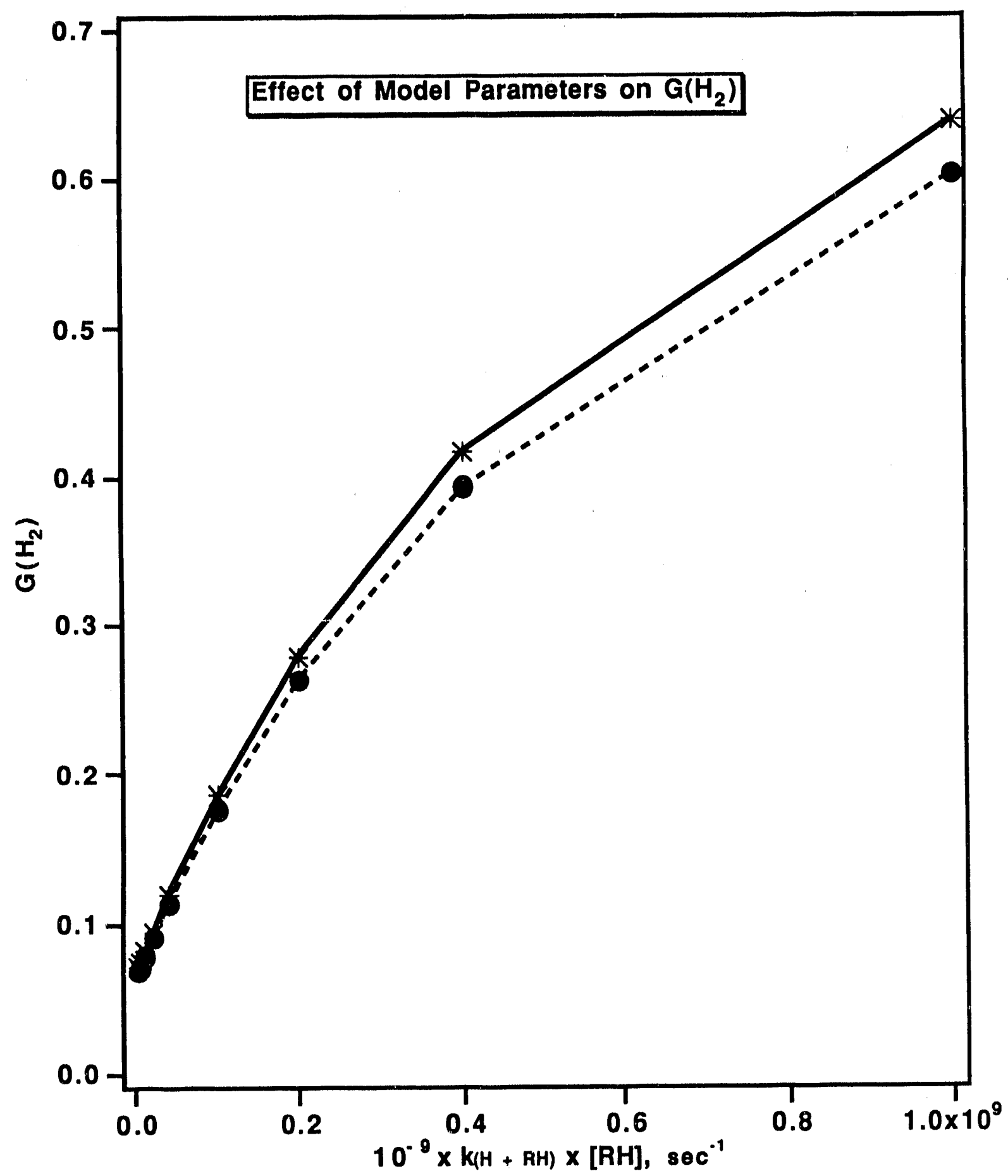

Figure 30. Calculated yield of $\mathrm{H}_{2}$ as a function of the rate of the hydrogen abstraction reaction (expressed as $\mathrm{k} \times[\mathrm{RH}]$ in units of $\mathrm{s}^{-1}$ ). Ccmputation was done for two extreme model parameters: "small spur" (stars) contains 2.8 water molecules fragmented per each ionization event and "large spur" (circles) contains six fragmented molecules. Concentrations of each nitrate, nitrite and hydroxide are $1 \mathrm{M}$. "Data" points represent concentrations for which the calculations were performed. 


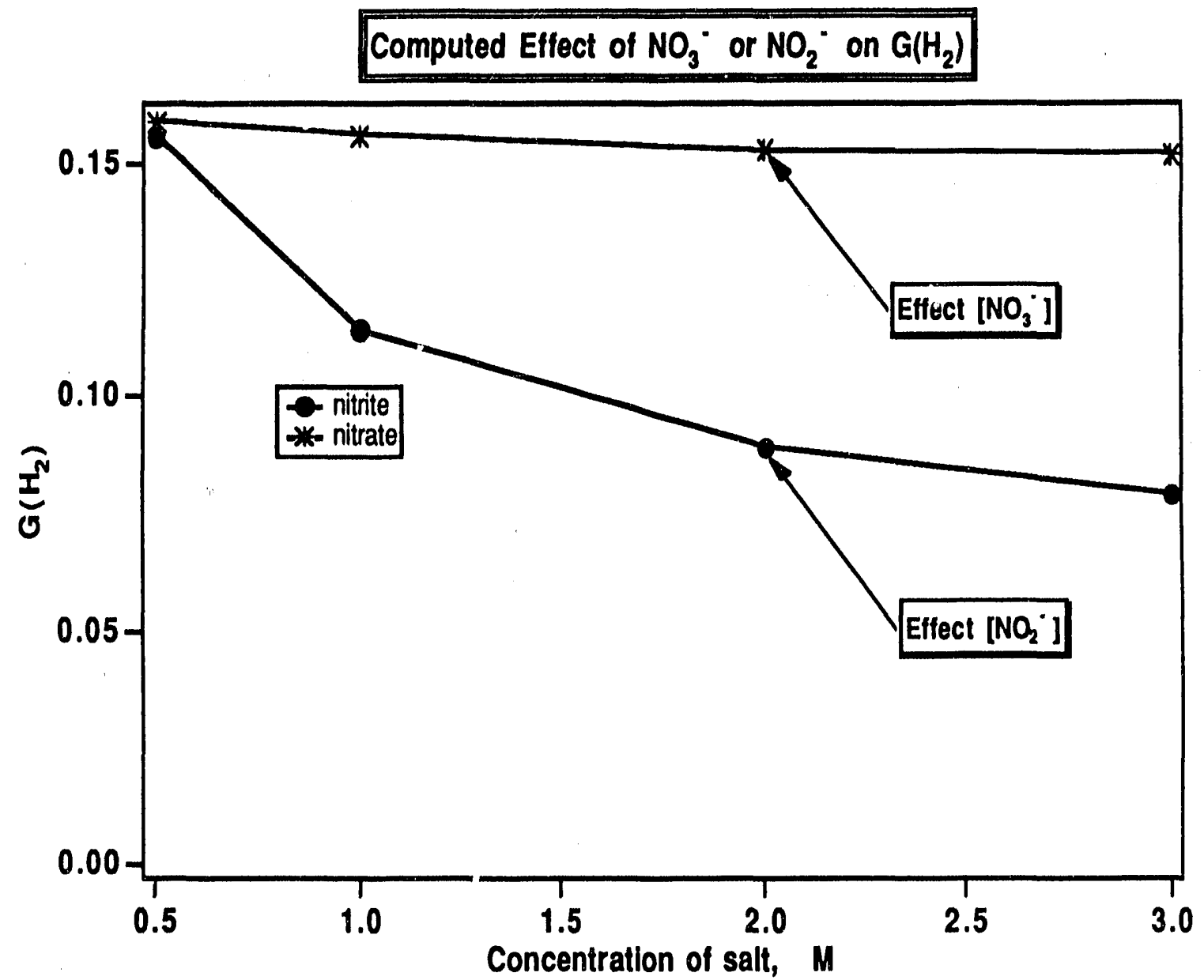

Figure 31. Calculated effect of nitrite and nitrate on the yield of $\mathrm{H}_{2}$. Assumed concentrations are $1.0 \mathrm{M} \mathrm{NaOH}$ for both; $0.5 \mathrm{M} \mathrm{NaNO}_{2}$ for the nitrate effect; $1.0 \mathrm{M} \mathrm{NaNO}_{3}$ for the nitrite effect; $\mathrm{k} \times[\mathrm{RH}]=4 \times 10^{7} \mathrm{~s}^{-1}$ for both. "Data" points represent concentrations for which the calculations were performed. 
37

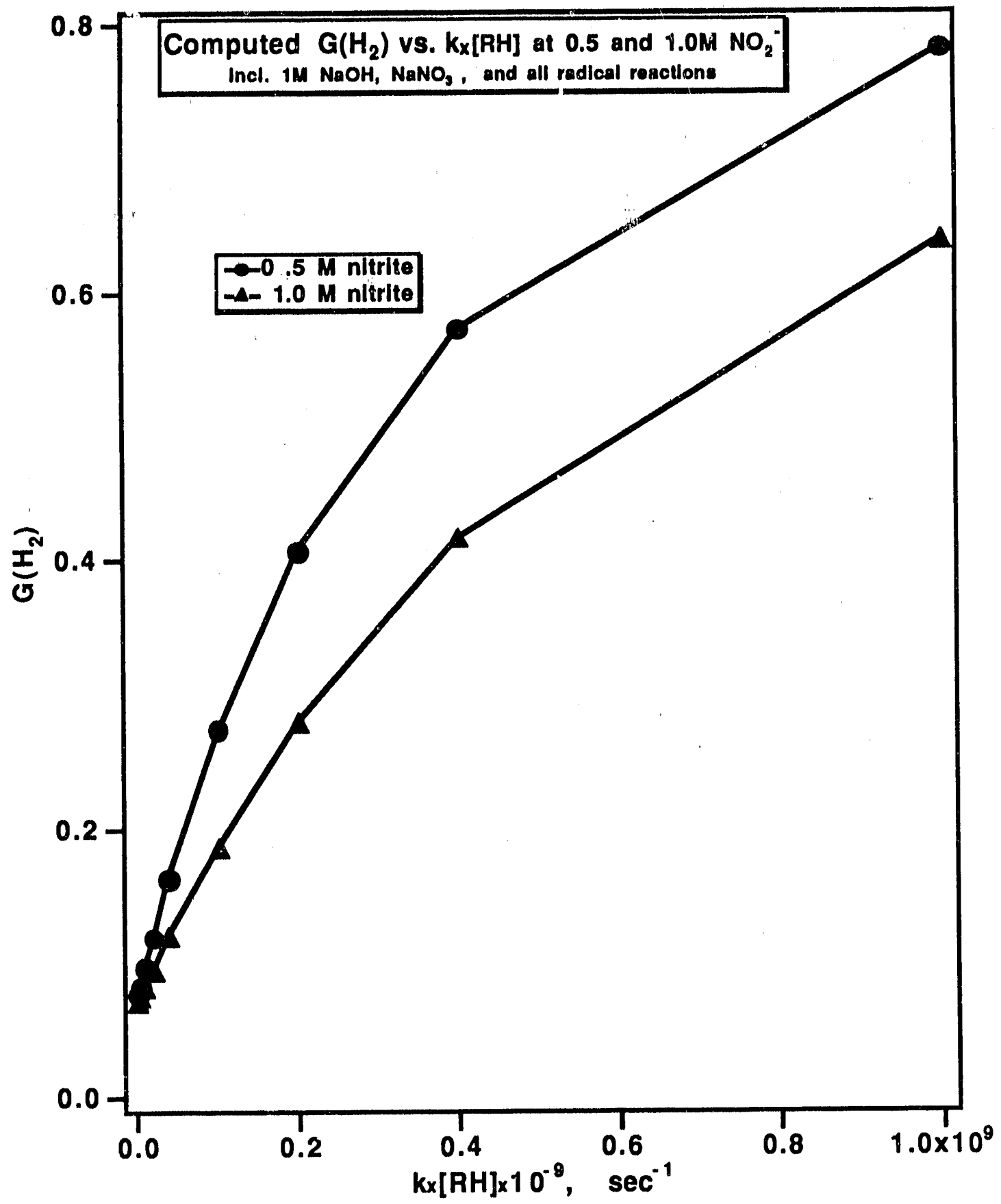

Figure 32. Computed yield of radiolytically generated $\mathrm{H}_{2}$ as a function of the rate of the $\mathrm{H}$ abstraction reaction. Concentrations of nitrate and hydroxide are $1 \mathrm{M}$. Concentrations of nitrite are shown in the figure. "Data" points represent concentrations for which the calculations were performed. 


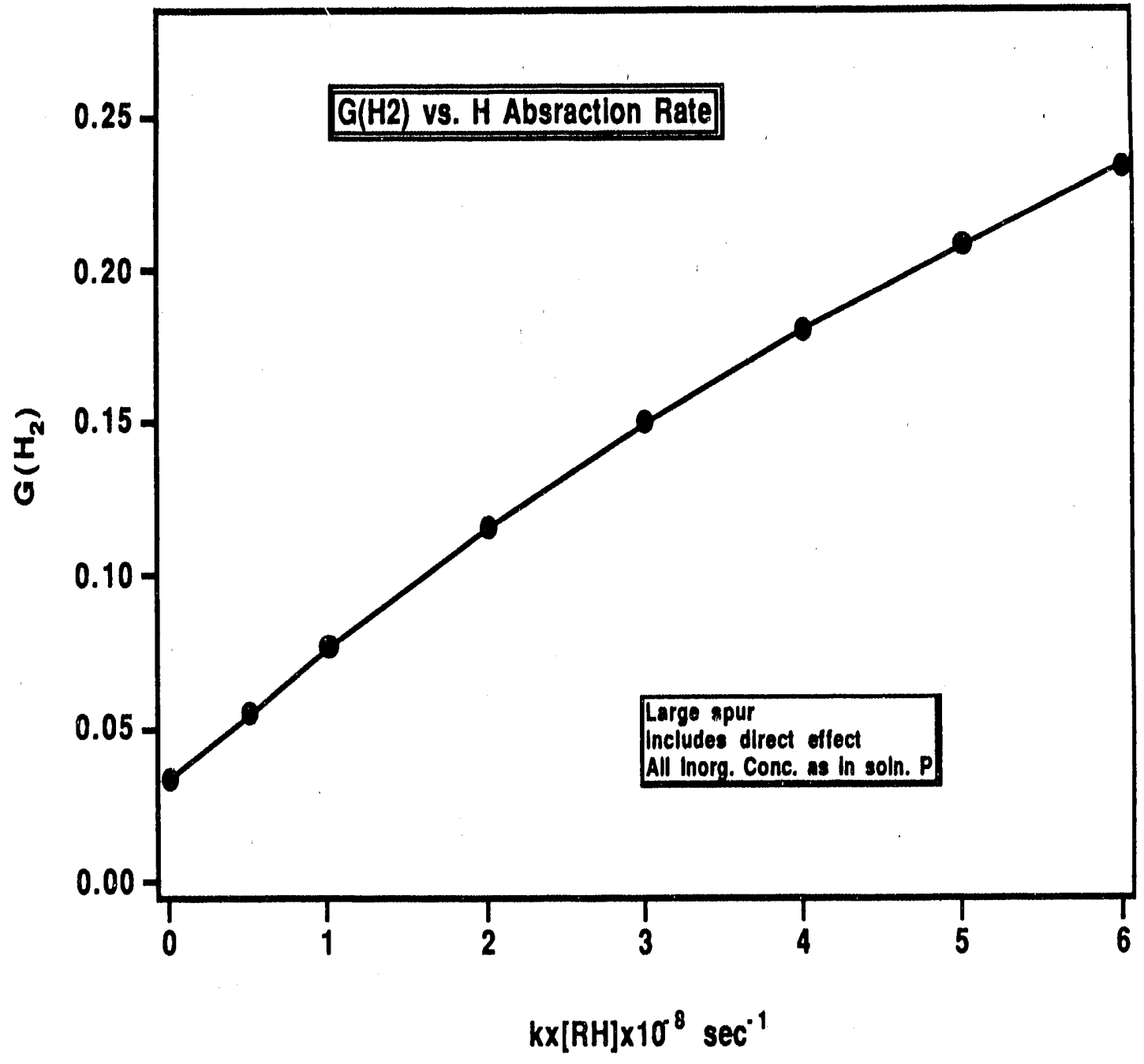

Figure 33. Yield of $\mathrm{H}_{2}$ as a function of revised rate for the $\mathrm{H}$-atom abstraction reaction from the organic solute. All concentrations of the inorganic solute are the same as in Solution P. Also includes the "direct effect". "Data" points represent concentrations for which the calculations were performed. 
ii. Hydrogen Peroxide Yields. It has been suggested that $\mathrm{H}_{2}$ may be formed by the reaction of $\mathrm{H}_{2} \mathrm{O}_{2}$ with radiolysis products. ${ }^{8}$ The yields of $\mathrm{H}_{2} \mathrm{O}_{2}$ as a function of several parameters was, therefore, calculated using the same model that was used for the calculation of $\mathrm{H}_{2}$. Results are shown in Fig. 34. As can be seen in Fig. 34, sensitivity to model parameters is greater for these estimates than for estimates of $\mathrm{G}\left(\mathrm{H}_{2}\right)$. The results suggest values of $\mathrm{G}\left(\mathrm{H}_{2} \mathrm{O}_{2}\right)=0.05$ 0.15. Also shown in Fig. 34 is the effect of organic additives on the yield of $\mathrm{H}_{2} \mathrm{O}_{2}$. The yield of hydrogen peroxide decreases with increasing concentration of organic solutes because the organic solute acts as an $\mathrm{OH}$-radical scavenger, a precursor radical to $\mathrm{H}_{2} \mathrm{O}_{2}$. The calculations overestimate the yield of $\mathrm{H}_{2} \mathrm{O}_{2}$ because the assumption was made that all of the oxidizing radicals were initially $\mathrm{OH}$ radicals. However, direct ionization of $\mathrm{NO}_{2}^{-}$and $\mathrm{NO}_{3}^{-}$would give $\mathrm{NO}_{2}$ and $\mathrm{NO}_{3}$ radicals rather than $\mathrm{OH}$ radicals. The resulting chemistry of these radicals is rather complex (see our literature report ${ }^{1}$ ), but it is unlikely to generate hydrogen peroxide. Therefore, it is clear that the calculations provide only an upper limit to the yield of $\mathrm{H}_{2} \mathrm{O}_{2}$. The amount of $\mathrm{H}_{2} \mathrm{O}_{2}$ that will be converted to $\mathrm{H}_{2}$ depends on the entire chemical system; this question is beyond the scope of our mission. Observations from Georgia Tech show that formaldehyde, a likely radiolytic degradation product of the chelators, reacts with $\mathrm{H}_{2} \mathrm{O}_{2}$ to give $\mathrm{H}_{2}$ with $100 \%$ efficiency. ${ }^{8}$

iii. $\mathrm{N}_{2} \mathrm{O}$ Production Mechanisms. The $\mathrm{NO}_{\mathrm{x}}$ system is very complicated because several stable, but reactive, intermediates are formed during the radiolysis. The complex reaction scheme that is described in Ref. 1 was solved using a chemical-kinetics equation-solving computer program. This mechanism does not address the reactions in the presence of organics (largely unknown), but it does describe the relevant chemistry in the absence of organics.

Calculations were done using several different assumptions for the mechanism of the direct effect and for different pathways for the destruction of the primary $\mathrm{H}$ and $\mathrm{OH}$ radicals. Typical results are shown in Fig. 35. For all cases studied, the steady-state concentration of the various $\mathrm{NO}_{\mathrm{x}}$ radical species will be in the $10^{-8} \mathrm{M}$ range and the $\mathrm{N}_{2} \mathrm{O}_{\mathrm{x}}$ concentrations will be in the $10^{-12} \mathrm{M}$ range. No result is presented for $\mathrm{N}_{2} \mathrm{O}$ in Fig. 35 because none was obtained in the calculations. The depletion in $\mathrm{NO}_{3}^{-}$and increase in $\mathrm{NO}_{2}^{-}$concentration will be small. The data shown in Fig. 35 predict a shift of approximately $7 \mathrm{mM}$ per year in the latter two concentrations under the conditions in tank 101-SY. The direction and precise amount of the shift depend on the assumptions made about the direct effect, but the order of magnitude of the shift is persistent - small relative to the total concentration of $\mathrm{NO}_{3} / \mathrm{NO}_{2}^{-}$. Again, it is emphasized that no reaction of organic solute was included in these calculations due to paucity of information.

The primary result relevant to the tank chemistry is that little or no $\mathrm{N}_{2} \mathrm{O}$ will be formed in the absence of the organic additives. This is consistent with the experimental results. Both the theoretical and experimental results may appear to be surprising because $\mathrm{NO}$ is formed radiolytically and it is known that $\mathrm{NO}$ will form $\mathrm{N}_{2} \mathrm{O}$ in the presence of high-hydroxide concentrations. However, the mechanism to produce $\mathrm{N}_{2} \mathrm{O}$ from $\mathrm{NO}$ must require at least two molecules of NO; hence, a strong dependence on its concentration may be expected (high reaction order). In the radiolytic system there are other mechanisms for the destruction of NO, which will limit the steady-state concentration to approximately $10^{-8} \mathrm{M}$. Thus, the mechanism for $\mathrm{N}_{2} \mathrm{O}$ formation that takes place at high concentrations of base will be ineffective under tank conditions in the absence of organic additives. 


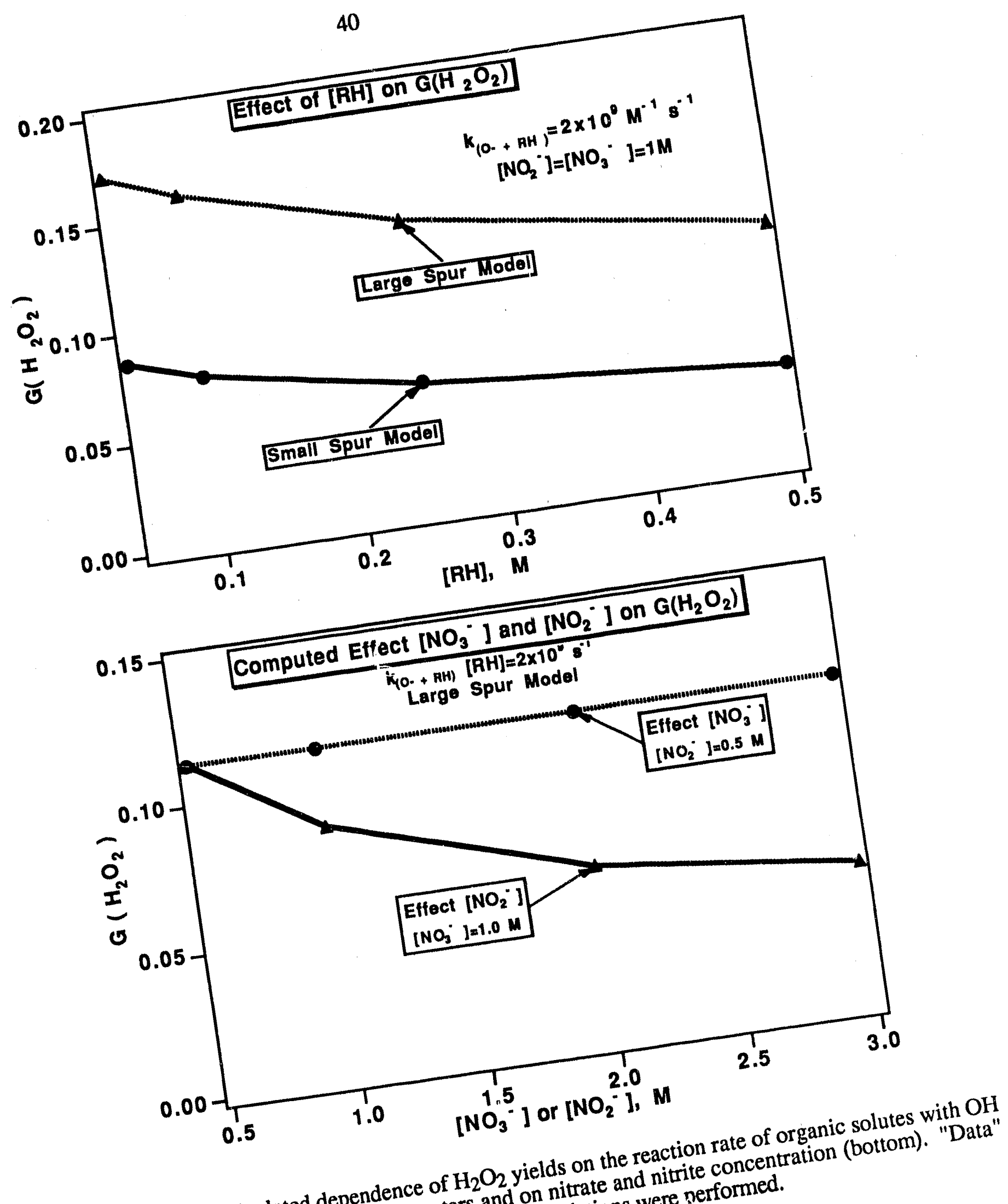

Figure 34. Calculated dependence of $\mathrm{H}_{2}$ and on nitrate and nitrite nerformed. radicals (top) for two model parations for which the calculations points represent concentrations for which 


\section{Changes In NOx System with Time}
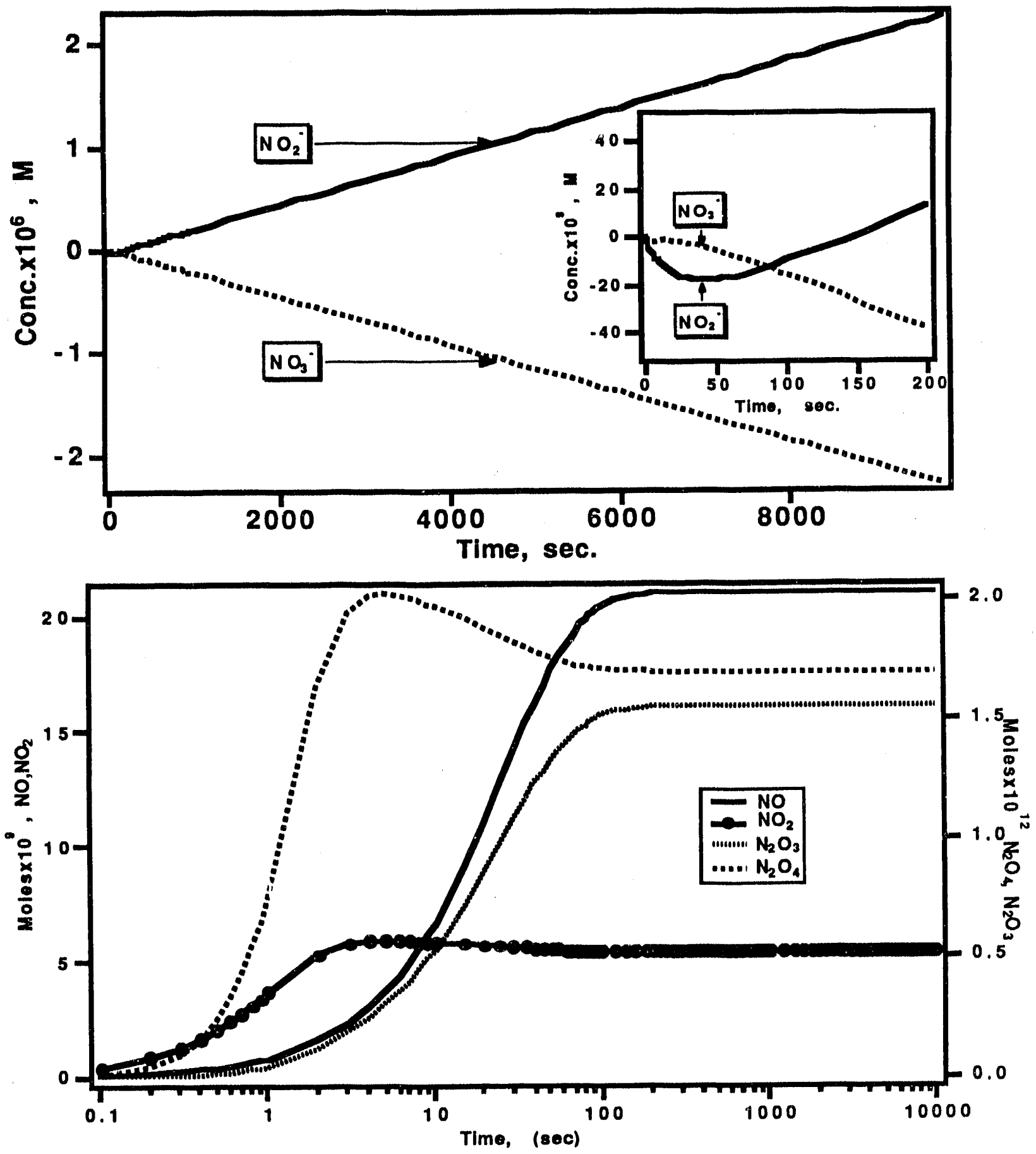

Figure 35. Changes in the nitrate and nitrite concentration (top) and accumulation of intermediates (bottom) as a result of radiolysis $(0.025 \mathrm{krad} / \mathrm{min}$; assumed in 101-SY). No reaction with organic solutes was included. 


\section{CONCLUSIONS}

The studies described above utilized a simulated waste solution and simulated radiation sources. The question may be raised as to the extent that these simulations truly reflect conditions in tank 101-SY. Appendix C compares the information available to us on the radiation sources in the tank with the radiation sources used in this study. The conclusions from this comparative examination are: a) The contribution from $\alpha$-irradiation sources in the tank to the total yield of $\mathrm{H}_{2}$ is less than $1 \%$ and, thus, can be neglected. b) The differences between the ${ }^{60} \mathrm{Co} \gamma$ source used for the simulated studies and the mostly $\beta$-radiation sources in the tank are of no consequence to the mechanisms of $\mathrm{H}_{2}$ generation. This conclusion is further justified in a separate report. ${ }^{9}$ c) Most of the experiments described in this report were conducted at much higher dose rates than those existing in the tank. The results described above in Section $2 b-i$ show that the difference in dose rate will have no effect on the yield of $\mathrm{H}_{2}$. On the other hand, the yield of $\mathrm{N}_{2} \mathrm{O}$ was found to increase with the decrease in dose rate at $30^{\circ} \mathrm{C}$. Therefore, to the extent that the chemical composition of the simulated waste mimics the chemical composition in 101-SY, the yields of $\mathrm{N}_{2} \mathrm{O}$ measured in the present studies are only a lower limit to what might be expected in the tank. As no dose-rate dependence of $\mathrm{G}\left(\mathrm{N}_{2} \mathrm{O}\right)$ was found at $60^{\circ} \mathrm{C}$ (the prevailing temperature in the tank), the yield in the tank would approach the yields observed in this study. As will become evident from the foregoing discussion, the extent to which the chemical composition of our solutions reflects 101-SY is less clear.

The radiolysis of an aqueous solution creates the following fragmentation products:

$$
\mathrm{H}_{2} \mathrm{O} M \mathrm{e}_{\mathrm{aq}}^{-}, \mathrm{H}, \mathrm{OH}, \mathrm{H}_{2}, \mathrm{H}_{2} \mathrm{O}_{2}
$$

The yield $\mathrm{G}\left(\mathrm{H}_{2}\right)=0.031$ measured from Solution $P$ in the absence of organic solutes results primarily from the fragmentation of energy-rich water molecules to generate directly $\mathrm{H}_{2}$ (reaction 4). Because water constitutes the major component of the solution and, thus, the primary absorber of energy, this contribution to the $\mathrm{H}_{2}$ yield is difficult to eliminate. Removal of radionuclides will, of course, eliminate this, or any other, radiolytic hydrogen source.

Further, we have measured: a) the rate constants of reaction 1 at high ionic strength in very

$$
\mathrm{H}+\mathrm{RH} \rightarrow \mathrm{H}_{2}+\mathrm{R}
$$

basic solutions for the chelators and their immediate degradation products that presumably are present in tank 101-SY, and b) the $\mathrm{H}_{2}$ yield in the simulated waste solutions as a function of the concentration of these organic additives. The results establish reaction 1 to be a second source of the radiolytically generated $\mathrm{H}_{2}$. The most efficient competitor for $\mathrm{H}$ atoms in the waste solutions is nitrite and its significance has been emphasized throughout this report.

It was further shown in this study that organic solutes are required for the radiolytic generation of $\mathrm{N}_{2} \mathrm{O}$. The results, so far, do not allow the development of a unique mechanism for the generation of $\mathrm{N}_{2} \mathrm{O}$, but our modeling calculations also conclude that in the absence of organic solutes the generation of $\mathrm{N}_{2} \mathrm{O}$ will be minimal. Thus, removal of the organic solutes will eliminate the radiolytic formation of $\mathrm{N}_{2} \mathrm{O}$ and will minimize (albeit not completely prevent) the radiolytic generation of $\mathrm{H}_{2}$. Whatever mechanism may be established for the radiolytic $\mathrm{N}_{2} \mathrm{O}$ generation, we have clearly shown that the major source for $\mathrm{N}_{2} \mathrm{O}$ derives from $\mathrm{NO}_{\mathbf{x}}{ }^{-}$and not from nitrogen-containing chelators.

An important observation on the radiolytic effects on the generation of gases is the finding that thermal production of the gases is enhanced by the radiolysis of the simulated waste solution. It is clear from our results that some long-lived degradation product, perhaps formaldehyde (as suggested by the Science Panel ${ }^{3}$ and by the Georgia Tech team ${ }^{8}$ ), is generated during long-term 
irradiation of simulated waste solutions and this product enhances the thermal generation of $\mathrm{H}_{2}$ and $\mathrm{N}_{2} \mathrm{O}$. This long-lived intermediate cannot be any of the degradation products that were specifically tested here (NTA, IDA, glycolate, etc.), but identifying this intermediate may require a significant analytical effort. Early and preliminary reports on the organic composition of core samples from 101-SY show that the original chelators and their immediate degradation products can account for only $10-20 \%$ of the total organic content. ${ }^{10}$ Taken together with our results on simulated waste solutions, both observations may require a shift in the program from the focus on the organic chelators to other likely degradation products. At any rate, removal of the organic solutes will also eliminate the thermal pathways for the radiolytically induced generation of the gases.

Whenever both gases were detccted in the experiments reported here, the ratio of $\mathrm{H}_{2} / \mathrm{N}_{2} \mathrm{O}$ was approximately $1: 10$. This is true for the radiolytically induced thermal generation of the gases as well as for the radiolytic pathways. In contrast, in the gases released during the venting events of tank 101-SY, the ratio is close to 1:1. The discrepancy may indicate that the mechanisms for gas generation in the simulated waste solutions are different from those in the tank. However, because the same $\mathrm{H}_{2} / \mathrm{N}_{2} \mathrm{O}$ 1:10 ratio is observed in thermal generation (radiolytically induced or in thermal experiments of others within the Waste Tank Safety Program ${ }^{11,12}$ ) as in radiolytic generation, it is more likely that other mechanisms that exist in the tank are absent in the simulation experiments. One such mechanism may include destruction of $\mathrm{N}_{2} \mathrm{O}$ in the tank, where its concentration is much higher than in our experiments. Another possibility is the preferential retention of one of the gases in the tank. Because our solutions so far included no heterogeneous particles, no retention is possible in these experiments. In view of the concerns raised above, the possibility that the composition of the simulated wastes deviate significantly from the actual waste in the tank carnot be discounted at present. 


\section{APPENDIX A. EXPERIMENTAI, TECHNIQUES}

The gas chromatography equipment used to measure yields of gases in irradiated solutions consists of three main parts: 1) A Van Slyke Manometric Apparatus; 2) Infotronics Model 15C-3 Gas Chromatograph; 3) A recorder-integrator ("ChromJei Integrator" Spectra Physics, Inc.). These are described briefly below.

A. Van Slyke Manometric Apparatus (Fig. A-1). The Van Slyke apparatus has been in use for many years to analyze gases formed by irradiation of aqueous and organic solutions. It has undergone a number of changes to update it for new equipment now in use, but basically it is the same and is an excellent way of extracting gases from solutions and introducing them into the desired detection device, such as a gas chromatograph or mass spectrometer. For a more complete description of the theory, use, and operation of this equipment, see ref. 13.

B. Infotronics Model 15C-3 Gas Chromatograph (Figs. A-2 and A-3). The Model 15C3 gas chromatograph is a rugged gas chromatograph designed for isothermal applications requiring high performance. The basic instrument incorporates a high signal-to-noise ratio, hot wire type thermal conductivity detector, a very stable detector power supply, an electronic proporional temperature controller, and a dual column flow system.

1. Basic chromatograph. The system consists of the following elements:

a. Separating columns. The separating columns are homemade 1/4-inch-diameter, 6-footlong copper tubing filled with the appropriate separating material.

b. Carrier gas. For most of our experiments we use argon and adjust the flow rate to about 60 $\mathrm{cc} / \mathrm{min}$.

c. Flow-control equipment, reducing valves, and needle valves to maintain a controlled flow of carrier gas through the columns.

d. Sample introduction device, located upstream from the separating columns. In our case this is the Van Slyke Gas apparatus, fitted with a four-way stopcock and male ball joints that connect to the Model 15C-3 gas chromatograph that has been fitted with female ball joints. With this type of system, the standard hypodermic needle injection ports are no longer in service. The Van Slyke - gas chromatograph interface is shown in Fig. A-3.

e. Thermal conductivity detection device for measuring the quantity of the separated components eluted from the columns, i.e., hot-wire filaments in a thermostated block.

f. Ovens to house the columns and detector with temperature-control devices to maintain desired operating conditions.

2. Calibration: Air ( $21 \%$ oxygen and $78 \%$ nitrogen), pure hydrogen, and pure $\mathrm{N}_{2} \mathrm{O}$ samples are used to calibrate the apparatus for its response to the corresponding gases.

3. Measurements: Typical conditions for $\mathrm{H}_{2}$ (and $\mathrm{O}_{2}, \mathrm{~N}_{2}$ ) and for $\mathrm{N}_{2} \mathrm{O}$ are given in Scheme A-1.

C. Irradiation Sources and Dosimetry (Figs. A-4 and A-5). The ${ }^{60}$ Co source shown in Fig. A-4 has been used only with the samples supported in the set of holes (Fig. A-5) nearest the source, where the dose rate is $0.56 \mathrm{krad} / \mathrm{min}$. Samples and dosimetry solutions are contained in syringes (see Fig. A-5). Another ${ }^{60} \mathrm{Co}$ source has been used with samples in syringes supported in wooden or metal racks at reproducible distances from an array of source rods. Dosimetry has been established at four distances from the array of rods. The rack holds six samples, and dosimetry is measured for each position in the rack. The average dose rates at the four distances are: $20 \mathrm{~cm}, 17 \mathrm{krad} / \mathrm{min} ; 48 \mathrm{~cm}, 4.4 \mathrm{krad} / \mathrm{min} ; 140 \mathrm{~cm}, 0.55 \mathrm{krad} / \mathrm{min} ; 254 \mathrm{~cm}, 0.177 \mathrm{krad} / \mathrm{min}$.

Dosimetry was done by measuring the production of $\mathrm{Fe}^{+3}$ spectrophotometrically in Fricke dosimeter solutions containing $1 \mathrm{mM} \mathrm{NaCl}{ }^{4}$ 
Typical Experimental Conditions - GC

\begin{tabular}{|c|c|c|}
\hline \multicolumn{3}{|c|}{ 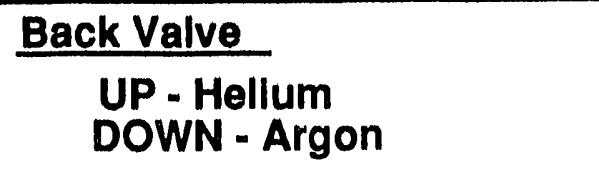 } \\
\hline \multicolumn{3}{|c|}{ Running Conditions } \\
\hline Gas psi & ball & ma \\
\hline Argon & 7.2 & 55 \\
\hline \multicolumn{3}{|c|}{$\left.\begin{array}{ll}\begin{array}{l}\text { Oven } \\
\text { Base }\end{array} & 0 \\
\text { Temp } & 0\end{array} \quad\right\}=$ R. T. } \\
\hline \multicolumn{3}{|c|}{ Temperature Controls } \\
\hline $\begin{array}{l}\text { Oven base } \\
\text { Oven Temp } \\
\text { basicaily runni } \\
\text { temperature on }\end{array}$ & $\begin{array}{l}\text { at roc } \\
\text { he det }\end{array}$ & $\begin{array}{l}0 \\
0 \\
m \\
\text { ector. }\end{array}$ \\
\hline
\end{tabular}

Columns : $6 \mathrm{ft} 1 / 4$ "copper in ref. side and $9 \mathrm{ft}$ copper $1 / 4$ "In sampling side filled with $13 \times$ molecular sleve

\begin{tabular}{|ccc|}
\hline Gas & $\begin{array}{c}\text { Retention time } \\
(\mathrm{min})\end{array}$ & $\begin{array}{c}\text { Sensitivities } \\
\text { (umoles/area unit) }\end{array}$ \\
\hline $\mathrm{H}_{2}$ & 1.92 & $1.07 \times 10^{-6}$ \\
$\mathrm{O}_{2}$ & 2.91 & $1.23 \times 10^{-5}$ \\
$\mathrm{~N}_{2}$ & 3.99 & $9.9 \times 10^{-6}$ \\
\hline
\end{tabular}

"Area units are defined by the integrator

\section{Analysis for $\mathrm{N}_{2} \mathrm{O}$ at ${ }^{n} 58^{\circ} \mathrm{C}$}

$9 \mathrm{ft}$ Molecular Sieve $13 \times$ column

16.5 psi Ar - flow 10.8 on ball flowmeter

50 MA detector current

Oven base heat 50

Oven temp control 500 (on basis of 1000 full scale)

Trim heat: High

\begin{tabular}{|ccc|}
\hline Gas & $\begin{array}{c}\text { Retention time } \\
\text { (min) }\end{array}$ & $\begin{array}{c}\text { Sensitivities } \\
\text { (umoles/area unit) }\end{array}$ \\
\hline $\mathrm{H}_{2}$ & 0.81 & $3.9 \times 10^{-6}$ \\
$\mathrm{O}_{2}+\mathrm{N}_{2}$ & 0.97 & $4.8 \times 10^{-5}$ \\
$\mathrm{~N}_{2} \mathrm{O}$ & 4.64 & $5.4 \times 10^{-5}$ \\
\hline
\end{tabular}




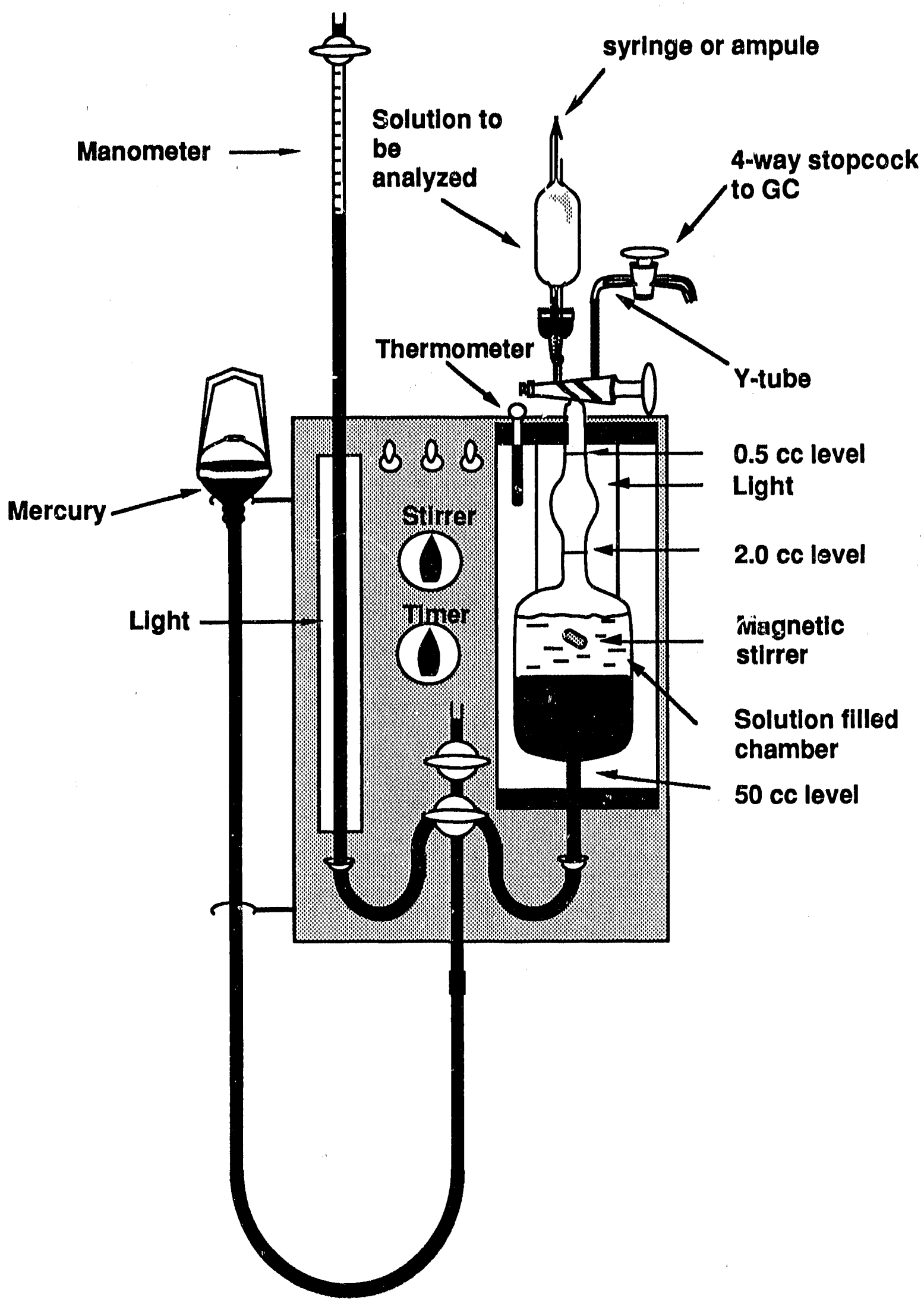

Figure A-1: Van Slyke apparatus for extraction of gases from irradiated solutions. 


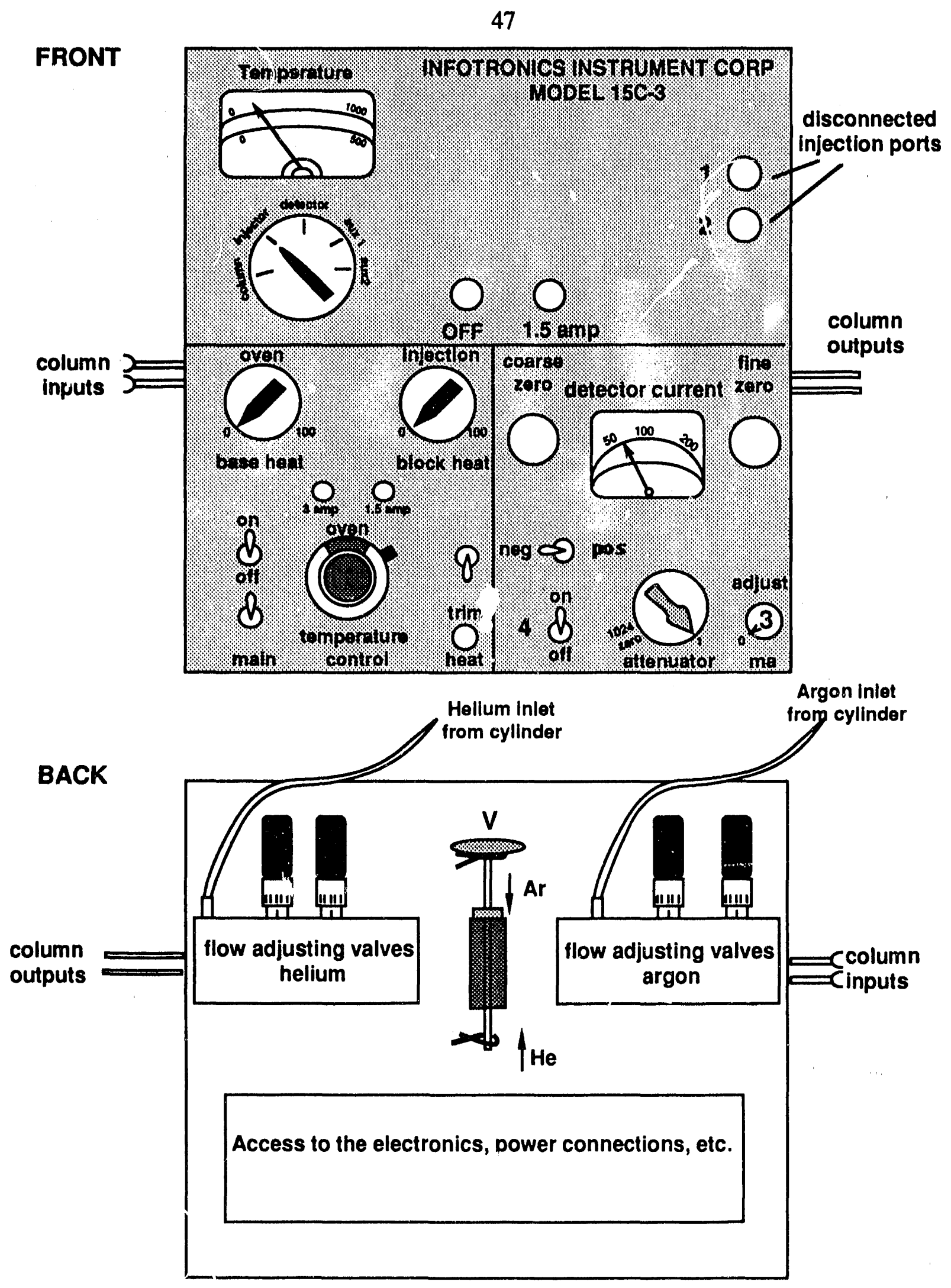

Figure A-2. Infotronics gas chromatograph: front panel. 


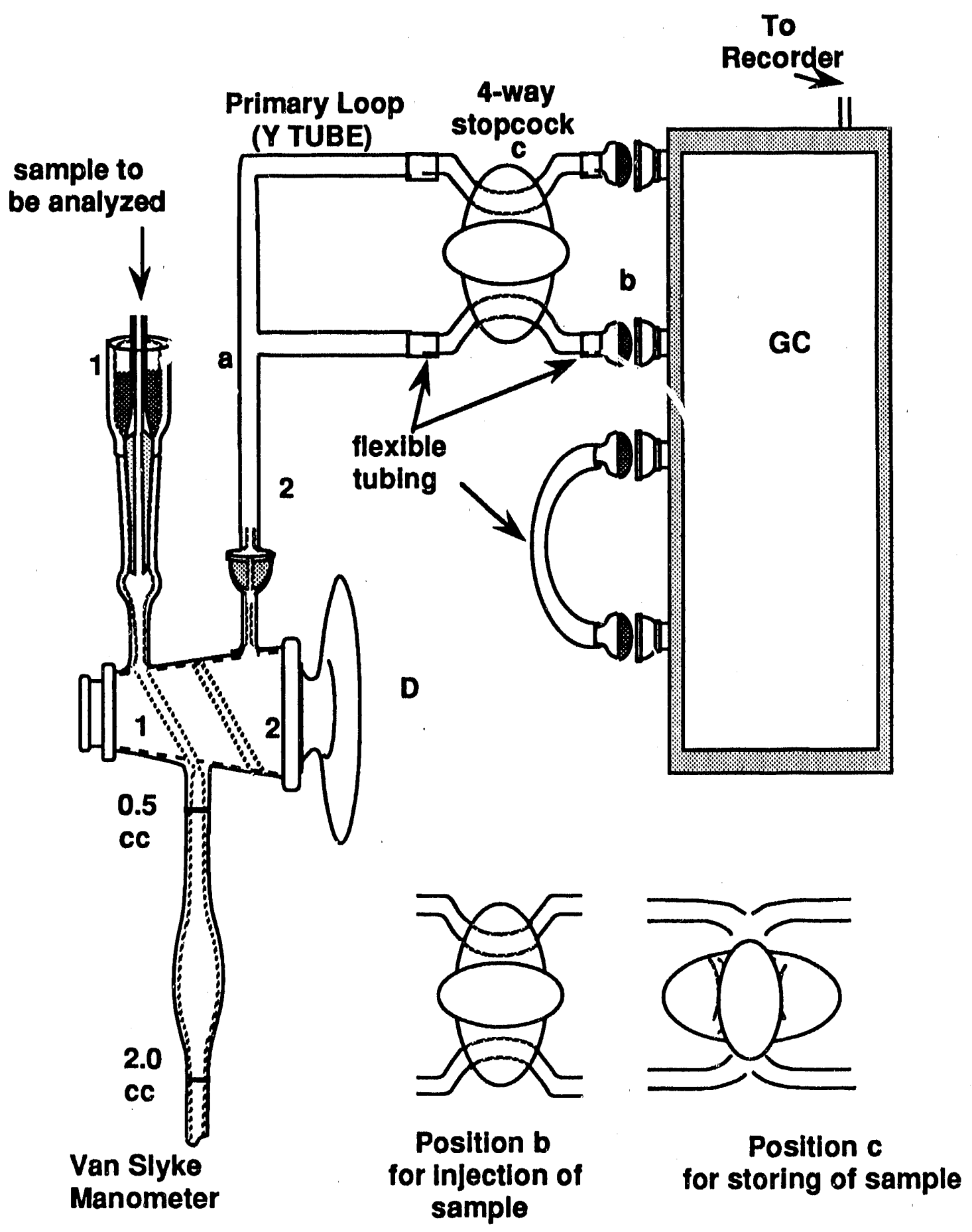

Figure A-3. Van Slyke-gas chromatograph interface. 
Multisource Chamber

$\mathrm{Co}^{60}$ source I-2

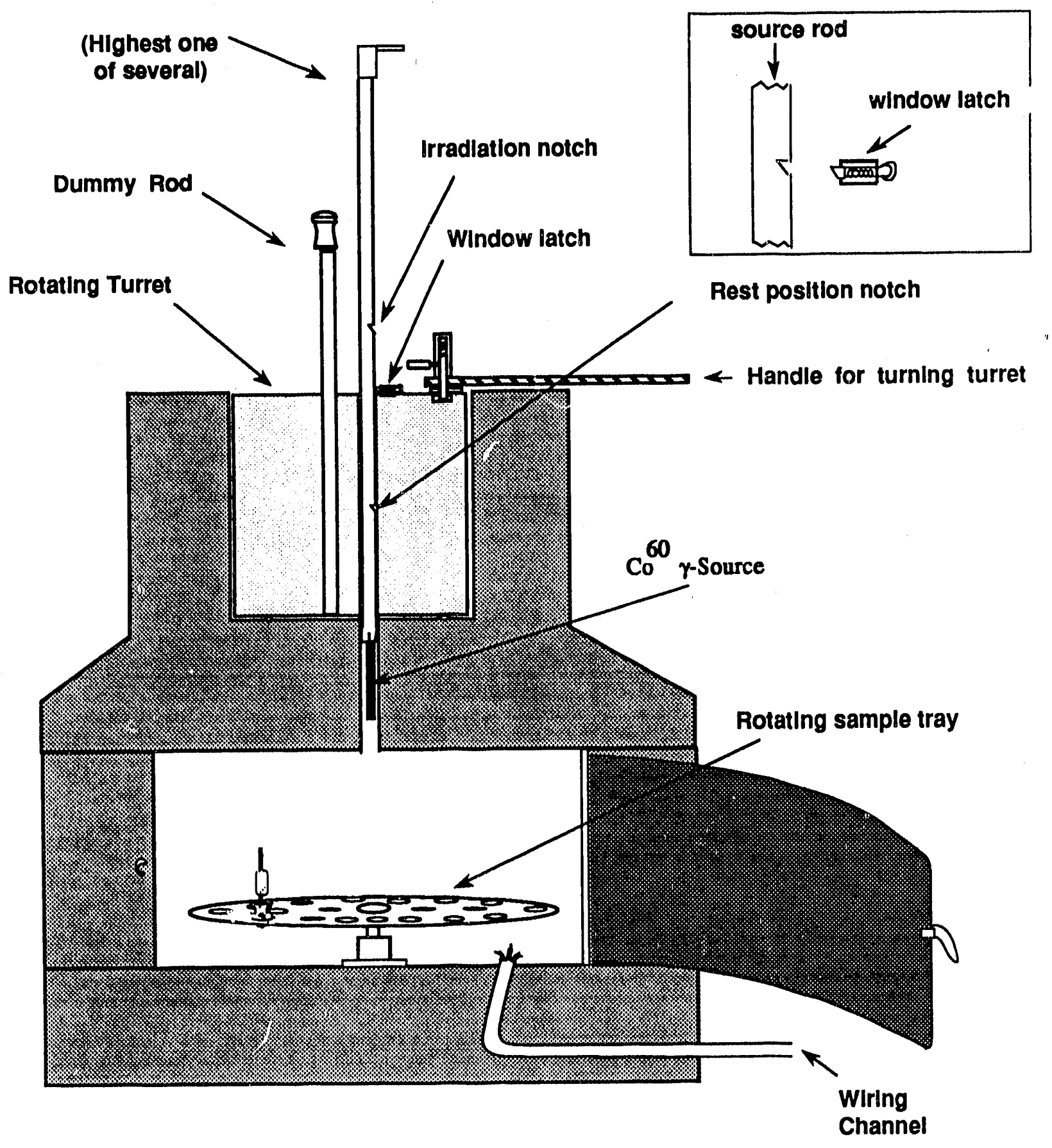

Figure A-4. Multisource irradiation chamber. 

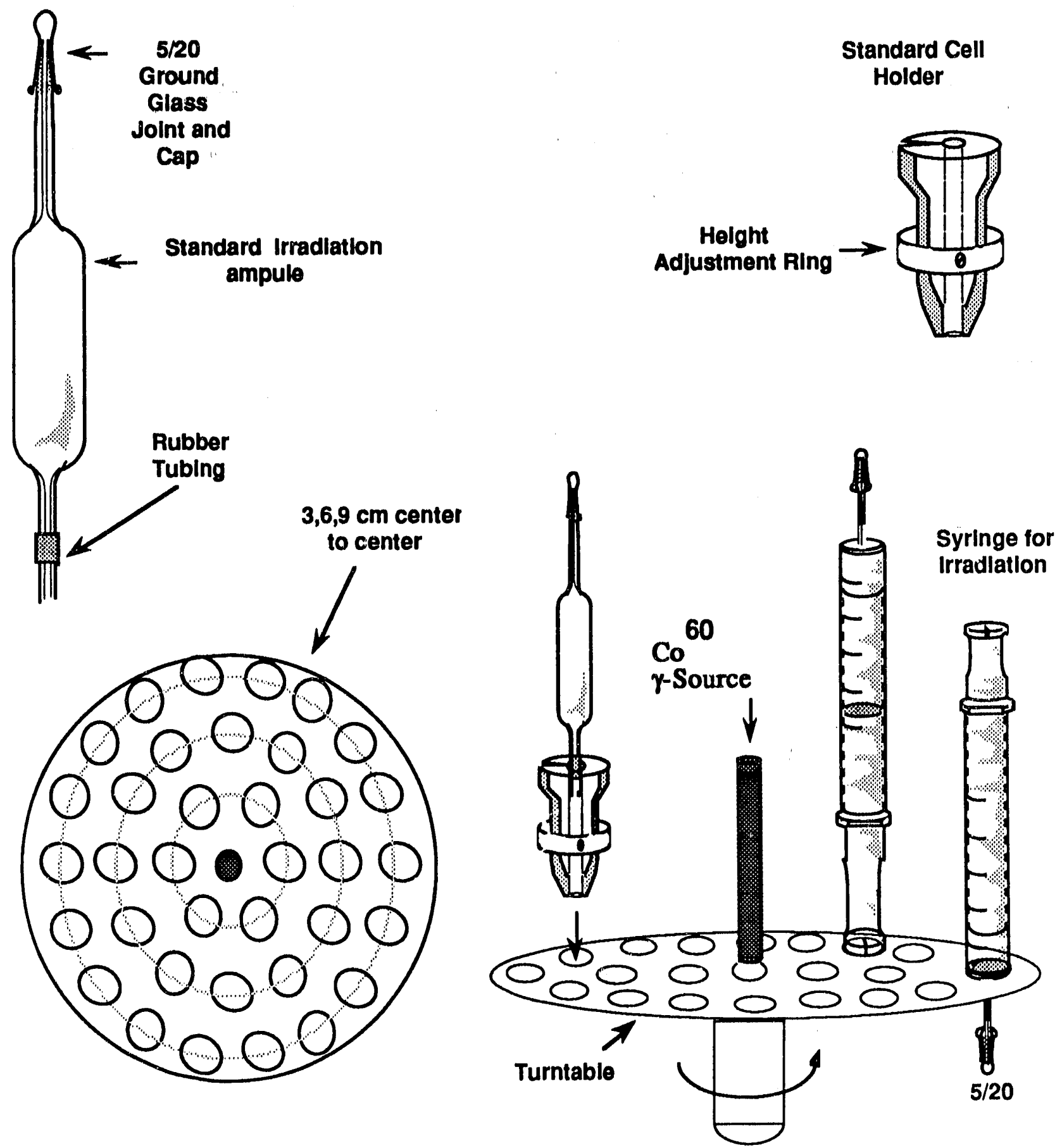

Figure A-5. Samples set up for multisource chamber. 


\section{APPENDIX B. MODELING PROCEDURES}

\section{B1. Nonhomogeneous Kinetics}

The radiation-chemical system is simulated by assuming that an ionizing event creates a spherically symmetric distribution of ions and radicals; this is the simulated spur. The concentration of each species is described by a continuous function that is determined by the distance from the center of the spur. Thus, a continuum approximation is used. A set of partial differential equations describes the diffusion and reactions of each of the species. The program numerically solves the partial differential equations for the spherically symmetric system. The equations were solved directly and neither the prescribed-diffusion model nor the modified prescribed-diffusion model was utilized. The program provides the time dependence of the concentration of each species. Of interest here is the time dependence of $\mathrm{H}_{2}$ molecules and $\mathrm{H}$ atoms. For the calculation of yields of $\mathrm{H}_{2} \mathrm{O}_{2}$, the time dependence of $\mathrm{OH}$ radicals and hydrogen peroxide were monitored. There is no pathway for the destruction of $\mathrm{H}_{2}$; therefore, the yield obtained at very early times, when the formation of $\mathrm{H}_{2}$ is complete, is also the yield at any later time. A typical result that shows the time dependence of the yield of $\mathrm{H}_{2}$ (and the decay of $\mathrm{H}$ atoms) is shown in Fig. $\mathrm{B}-1$.

The continuum approximation described here will overestimate second-order reactions of the type $\mathrm{OH}+\mathrm{OH}, \mathrm{e}_{\mathrm{aq}}+\mathrm{e}_{\mathrm{aq}}$, or $\mathrm{H}+\mathrm{H}$. In the chemical systems under study, the predominant reactions occur between radicals and the solutes and thus this overestimate is of little significance.

Two different spatial distributions for the radiolysis products were used. One was that devised by Trumbore and co-workers. ${ }^{14}$ This model accurately describes the decay of the hydrated electron and the $\mathrm{OH}$ radical experimentally measured in dilute aqueous solutions. The second was a model proposed by Kuppermann ${ }^{15}$ that gave decay rates of the hydrated electron considerably faster than experimentally determined. The parameters were modified as suggested by Kuppermann ${ }^{16}$ to improve the agreement with the measured decay of the hydrated electron. The initial yield of the hydrated electron was assumed to be 4.7 radicals $/ 100 \mathrm{eV}$ to agree with the data of Jonah et al. ${ }^{17}$ and to be in reasonable agreement with the calculations of Schwarz. ${ }^{18}$

The results of Fig. 33 were obtained by using a different set of yields. The high concentration of salts in the system means that water is not the only species initially ionized by the particle. Ionization of the salts can also occur. For the results of Fig. 33, the assumption was made that the yield of the electron will remain constant. This is reasonable because direct absorption of the radiation by solutes will invariably eject an electron. The yield of the hydrogen atom was decreased by the electron fraction of water in the system. Molecular $\mathrm{H}_{2}$ was decreased by the square of this value; the assumption was made that there must be two molecules of water nearby to form one molecule of $\mathrm{H}_{2}$. The resulting yields of $\mathrm{H}$ and $\mathrm{H}_{2}$ are in reasonable agreement with the experiments described in section 2.

All of the relevant parameters are given in Table B-1 and the reactions and rate constants are given in Table B-2. The same model and the same computational routines were used for estimates of $\mathrm{H}_{2} \mathrm{O}_{2}$ yields.

\section{B2. Homogeneous Kinetics}

The reactions and rate constants used for the homogeneous simulation of the $\mathrm{NO}_{\mathrm{x}}$ system are given in Table B-3. Two nitrate and two nitrite terms are found in these equations. One component is fixed (the one labeled with S in Table B-3) and the second can change. This allows accurate calculation of the changes in nitrite and nitrate concentrations (which might be very small) even though their total concentration is very high. The chemical equations were solved using a conventional Gear-type integrator. 


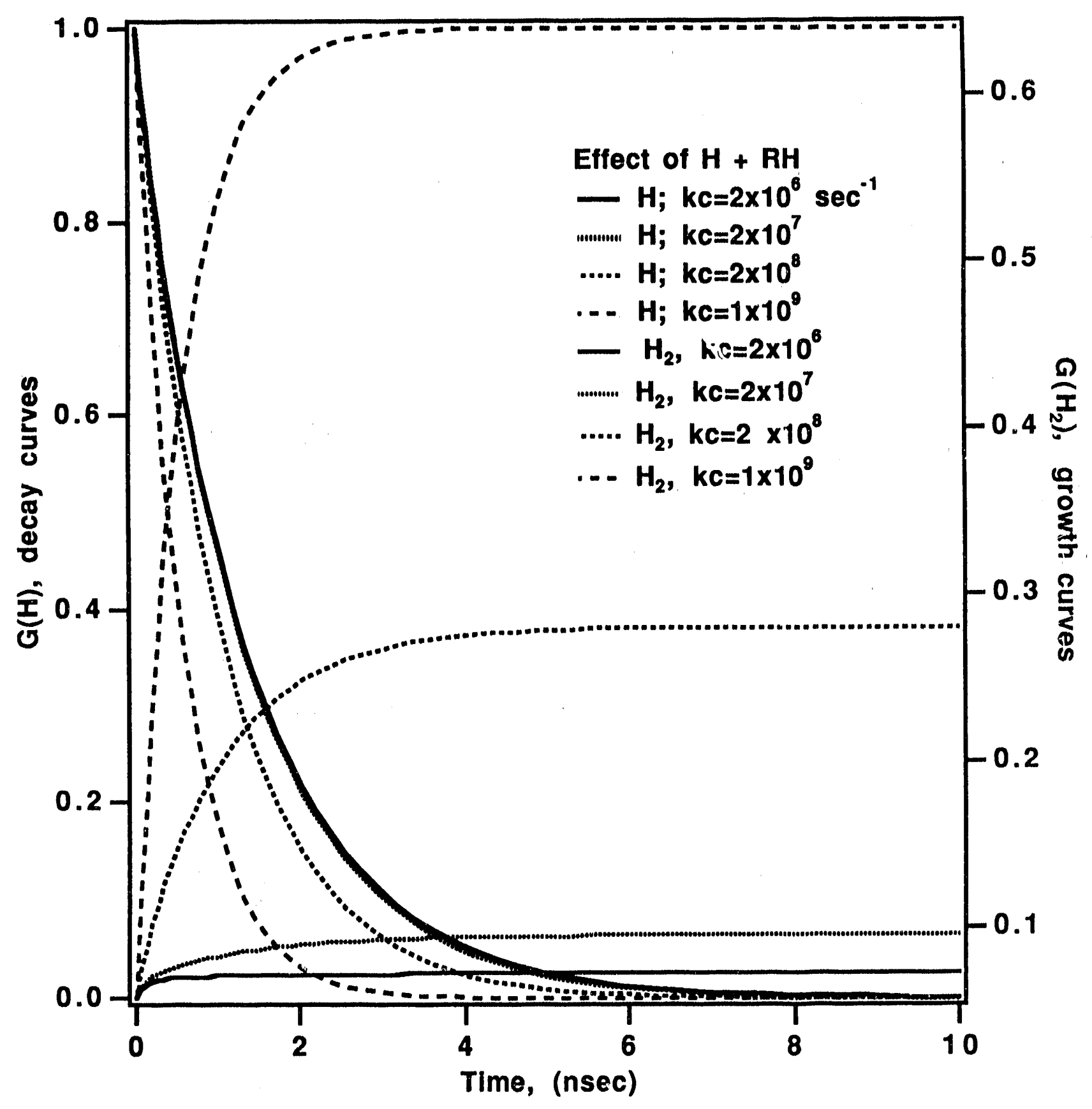

Figure B-1. Calculated time dependence of the disappearance of $\mathrm{H}$ atoms and generation of $\mathrm{H}_{2}$. The plateau values of $\mathrm{G}\left(\mathrm{H}_{2}\right)$ in curves similar to this one were used as the predicted $\mathrm{G}\left(\mathrm{H}_{2}\right)$ values in Figs. 30-33. Concentrations used in this calculation were $1.0 \mathrm{M}$ each of $\mathrm{NaOH}, \mathrm{NaNO}_{2}$, and $\mathrm{NaNO}_{3}$. 
Table B-1. Diffusion-model parameters used in the calculations of yields.

\begin{tabular}{|c|c|c|c|c|c|c|c|}
\hline \multirow[t]{2}{*}{ Species } & \multirow[t]{2}{*}{$\begin{array}{l}\mathrm{D} \times 10^{-5^{\mathrm{a}}} \\
\mathrm{cm}^{2} / \mathrm{sec}\end{array}$} & \multicolumn{3}{|c|}{$\begin{array}{c}\text { Initial Radius } \\
\left(\mathrm{r}_{0} \text { or } \mathrm{r}_{\mathrm{e}}\right)^{b} \\
\AA\end{array}$} & \multicolumn{3}{|c|}{$\begin{array}{l}\text { No. of Fragments } \\
\text { molecules/spur }\end{array}$} \\
\hline & & Big spur & Trumbore & Modified & Big spur & Trumbore & Modified \\
\hline$e_{a \bar{q}}$ & 4.5 & 60.00 & $23.10^{c}$ & $23.10^{c}$ & 6.000 & 2.820 & 2.820 \\
\hline $\mathrm{H}_{3} \mathrm{O}^{+}$ & 10.0 & 20.00 & 21.21 & 21.21 & 6.000 & 2.820 & 1.260 \\
\hline $\mathrm{OH}^{-}$ & 2.0 & & & & & & \\
\hline $\mathrm{OH}$ & 2.0 & 20.00 & 21.21 & 21.21 & 7.400 & 3.480 & 3.120 \\
\hline $\mathrm{H}_{2} \mathrm{O}_{2}$ & 1.4 & & & & & & \\
\hline $\mathrm{H}$ & 8.0 & 20.00 & 21.21 & 21.21 & 1.300 & 0.6000 & 0.4400 \\
\hline $\mathrm{H}_{2}$ & 2.0 & 20.00 & 21.21 & 21.21 & 0.074 & 0.035 & 0.016 \\
\hline
\end{tabular}

aThe values quoted were used in the calculations. They are not precise experimental values.

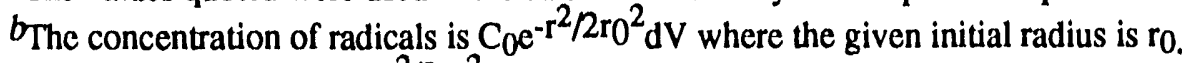

cThe distribution is $C_{e}{ }^{3} e^{-r^{2} / 2 r_{e}^{2}} d V$ where the given initial radius is $r_{e}$

Table B-2. Rate constants used in the calculations of radiation chemical yields.

\begin{tabular}{|c|c|c|c|c|c|c|c|}
\hline No. & Reactant & Reactant & $\begin{array}{c}\mathrm{k} \times 10^{-9} \\
\mathrm{M}^{-1} \mathrm{sec}^{-1}\end{array}$ & No. & Reactant & Reactant & $\begin{array}{c}\mathrm{k} \times 10^{-9} \\
\mathrm{M}^{-1} \mathrm{sec}^{-1}\end{array}$ \\
\hline 1 & $\mathrm{e}_{\mathrm{aq}} \overline{\mathrm{q}}$ & $e_{a \bar{q}}$ & 5.000 & 15 & $\mathrm{OH}$ & $\mathrm{NO}_{3}^{2-}$ & 5.000 \\
\hline 2 & $e_{a \bar{q}}$ & $\mathrm{H}_{3} \mathrm{O}^{+}$ & 23.00 & 16 & $\mathrm{OH}$ & $\mathrm{NO}_{2}$ & 10.00 \\
\hline 3 & $\mathrm{e}_{\mathrm{a} \overline{\mathrm{q}}}$ & $\mathrm{OH}$ & 30.00 & 17 & $\mathrm{OH}$ & RH & 2.000 \\
\hline 4 & $e_{\bar{a} \bar{q}}$ & $\mathrm{H}_{2} \mathrm{O}_{2}$ & 12.30 & 18 & $\mathrm{H}_{2} \mathrm{O}_{2}$ & $\mathrm{H}$ & 0.1600 \\
\hline 5 & $e_{\bar{a}}^{\bar{q}}$ & $\mathrm{H}$ & 25.00 & 19 & $\mathrm{H}$ & $\mathrm{H}$ & 10.00 \\
\hline 6 & $e_{\overline{a q}}$ & $\mathrm{NO}_{3}^{-}$ & 10.00 & 20 & $\mathrm{H}$ & $\mathrm{O}$ & 10.00 \\
\hline 7 & $e_{a \bar{q}}$ & $\mathrm{NO}_{2} \bar{z}$ & 4.000 & 21 & $\mathrm{H}$ & $\mathrm{NO}_{3}^{-}$ & 0.0014 \\
\hline 8 & $\mathrm{H}_{3} \mathrm{O}^{+}$ & $\mathrm{OH}^{-}$ & 143.0 & 22 & $\mathrm{H}$ & $\mathrm{NO}_{2}^{-}$ & 0.7000 \\
\hline 9 & $\mathrm{H}_{3} \mathrm{O}^{+}$ & o & 100.0 & 23 & $\mathrm{H}$ & RH & Variable \\
\hline 10 & $\mathrm{OH}^{-}$ & $\mathrm{OH}$ & 13.00 & 24 & o & o & 4.200 \\
\hline 11 & $\mathrm{OH}^{-}$ & $\mathrm{H}$ & 0.02 & 25 & 0 & $\mathrm{NO}_{3}^{-}$ & 5.000 \\
\hline 12 & $\mathrm{OH}$ & $\mathrm{OH}$ & 5.500 & 26 & $\mathrm{O}$ & $\mathrm{NO}_{2}$ & 0.3300 \\
\hline 13 & $\mathrm{OH}$ & $\mathrm{H}$ & 20.00 & 27 & $\mathrm{O}$ & RH & 1.000 \\
\hline 14 & $\mathrm{OH}$ & $\mathrm{O}^{-}$ & 20.00 & & & & \\
\hline
\end{tabular}


Table B-3. Reactions and rate constants used in the simulation of homogeneous kinetics for the $\mathrm{NO}_{\mathbf{x}}$ system.

\begin{tabular}{|c|c|c|c|c|c|c|c|c|}
\hline $\mathrm{NO}_{3}-2$ & + & $\mathrm{H}_{2} \mathrm{O}$ & $\rightarrow$ & $\mathrm{OH}^{-}+$ & + & $\mathrm{OH}^{-}$ & $+\mathrm{NO}_{2}$ & $\mathrm{k}=5.50 \times 10^{4} \mathrm{sec}^{-1}$ \\
\hline $\mathrm{NO}_{2}$ & + & $\mathrm{NO}_{2}$ & $\rightarrow$ & $\mathrm{N}_{2} \mathrm{O}_{4}$ & & & & $\mathrm{k}=4.50 \times 10^{8} \mathrm{M}^{-1} \mathrm{sec}^{-1}$ \\
\hline $\mathrm{N}_{2} \mathrm{O}_{4}$ & + & & $\rightarrow$ & $\mathrm{NO}_{2}$ & + & $\mathrm{NO}_{2}$ & & $\mathrm{k}=6.75 \times 10^{3} \mathrm{sec}^{-1}$ \\
\hline $\mathrm{N}_{2} \mathrm{O}_{4}$ & + & $\mathrm{H}_{2} \mathrm{O}$ & $\rightarrow$ & $\mathrm{NO}_{3}{ }^{-}$ & + & $\mathrm{NO}_{2}^{-}$ & $+2 \mathrm{H}^{+}$ & $\mathrm{k}=1.00 \times 10^{3} \mathrm{sec}^{-1}$ \\
\hline $\mathrm{NO}_{2}$ & + & NO & $\rightarrow$ & $\mathrm{N}_{2} \mathrm{O}_{3}$ & & & & $\mathrm{k}=1.10 \times 10^{9} \mathrm{M}^{-1} \mathrm{sec}^{-1}$ \\
\hline $\mathrm{N}_{2} \mathrm{O}_{3}$ & + & & $\rightarrow$ & NO & + & $\mathrm{NO}_{2}$ & & $\mathrm{k}=8.03 \times 10^{4} \mathrm{sec}^{-1}$ \\
\hline $\mathrm{N}_{2} \mathrm{O}_{3}$ & + & $\mathrm{H}_{2} \mathrm{O}$ & $\rightarrow$ & $\mathrm{NO}_{2}$ & + & $\mathrm{NO}_{2}^{-}$ & $+2 \mathrm{H}^{+}$ & $\mathrm{k}=5.30 \times 10^{2} \mathrm{sec}^{-1}$ \\
\hline $\mathrm{NO}_{2}^{-}$ & + & $\mathrm{OH}$ & $\rightarrow$ & $\mathrm{NO}_{2}$ & + & $\mathrm{OH}^{-}$ & & $\mathrm{k}=1.00 \times 10^{10} \mathrm{M}^{-1} \mathrm{sec}^{-1}$ \\
\hline$\$ \mathrm{NO}_{2}-$ & + & $\mathrm{OH}$ & $\rightarrow$ & $\mathrm{NO}_{2}$ & + & $\mathrm{OH}^{-}$ & $-\mathrm{NO}_{2}^{-}$ & $\mathrm{k}=1.00 \times 10^{10} \mathrm{M}^{-1} \mathrm{sec}^{-1}$ \\
\hline $\mathrm{NO}_{2}^{-}$ & + & $e_{a q^{-}}$ & $\rightarrow$ & $\mathrm{NO}_{2}-2$ & & & & $\mathrm{k}=4.10 \times 10^{9} \mathrm{M}^{-1} \mathrm{sec}^{-1}$ \\
\hline$\$ \mathrm{NO}_{2}-$ & + & $\mathrm{e}_{\mathrm{aq}}^{-}$ & $\rightarrow$ & $\mathrm{NO}_{2}-2$ & - & $\mathrm{NO}_{2}^{-}$ & & $\mathrm{k}=4.10 \times 10^{9} \mathrm{M}^{-1} \mathrm{sec}^{-1}$ \\
\hline $\mathrm{NO}_{2}$ & + & $\mathrm{H}$ & $\rightarrow$ & NO & + & $\mathrm{OH}^{-}$ & & $\mathrm{k}=7.10 \times 10^{8} \mathrm{M}^{-1} \mathrm{sec}^{-1}$ \\
\hline$\$ \mathrm{NO}_{2}$ & + & $\mathrm{H}$ & $\rightarrow$ & NO & + & $\mathrm{OH}^{-}$ & $-\mathrm{NO}_{2}{ }^{-}$ & $\mathrm{k}=7.10 \times 10^{8} \mathrm{M}^{-1} \mathrm{sec}^{-1}$ \\
\hline $\mathrm{NO}_{2}-2$ & + & $\mathrm{H}_{2} \mathrm{O}$ & $\rightarrow$ & NO & + & $\mathrm{OH}^{-}$ & $+\mathrm{OH}^{-}$ & $\mathrm{k}=1.00 \times 10^{3} \mathrm{sec}^{-1}$ \\
\hline $\mathrm{NO}_{3}^{-}$ & + & $e_{a q}^{-}$ & $\rightarrow$ & $\mathrm{NO}_{3}-2$ & & & & $\mathrm{k}=9.70 \times 10^{9} \mathrm{M}^{-1} \mathrm{sec}^{-1}$ \\
\hline$\$ \mathrm{NO}_{3}$ & + & $e_{\mathrm{aq}}^{-}$ & $\rightarrow$ & $\mathrm{NO}_{3}-2$ & - & $\mathrm{NO}_{3}^{-}$ & & $\mathrm{k}=9.70 \times 10^{9} \mathrm{M}^{-1} \mathrm{sec}^{-1}$ \\
\hline $\mathrm{NO}_{3}^{-}$ & + & $\mathrm{H}$ & $\rightarrow$ & $\mathrm{H}^{+}$ & + & $\mathrm{NO}_{3}^{-2}$ & & $\mathrm{k}=1.40 \times 10^{6} \mathrm{M}^{-1} \mathrm{sec}^{-1}$ \\
\hline$\$ \mathrm{NO}_{3}-$ & + & $\mathrm{H}$ & $\rightarrow$ & $\mathrm{H}^{+}$ & + & $\mathrm{NO}_{3}-2$ & $-\mathrm{NO}_{3}^{-}$ & $\mathrm{k}=1.40 \times 10^{6} \mathrm{M}^{-1} \mathrm{sec}^{-1}$ \\
\hline $\mathrm{NO}_{2}$ & + & $\mathrm{OH}$ & $\rightarrow$ & $\mathrm{NO}_{3}$ & + & $\mathrm{H}^{+}$ & & $\mathrm{k}=1.30 \times 10^{9} \mathrm{M}^{-1} \mathrm{sec}^{-1}$ \\
\hline
\end{tabular}

$\$$ indicates a species of high initial concentration whose change in concentration was, nonetheless, monitored. 


\section{APPENDIX C. COMPARISON OF RADIATION SOURCES}

The lowest dose rate utilized in our experiments was $0.18 \mathrm{krad} / \mathrm{min}$. The highest dose rate measured in tank $101-\mathrm{SY}$ is approximately $0.02 \mathrm{krad} / \mathrm{min}$. Table $\mathrm{C}-1$ summarizes the dose rates determined in 101-SY and converts them from $\mu \mathrm{Ci} / 1$ to $\mathrm{krad} / \mathrm{min}$. It can be seen from Table $\mathrm{C}-1$ that the contribution from transuranic elements ( $\alpha$ emitters) to the dose in the tank is very small. The yield of $\mathrm{H}_{2}$ from $\alpha$ radiolysis is higher than from $\beta$ or $\gamma$ radiolysis. Even if this yield is an order of magnitude higher in the former than in the latter (a gross overestimate) the contribution to $\mathrm{G}\left(\mathrm{H}_{2}\right)$ from $\alpha$ radiolysis in 101-SY is less than $1 \%$. The radiolysis source used in the present study is a ${ }^{60} \mathrm{Co} \gamma$ source. The radiation in 101-SY is largely $\beta$ irradiation. There are no significant differences in the chemical effects of $\gamma$ radiolysis relative to $\beta$ irradiation.

The following calculations were used to obtain the conversions in Table C-1:

a) To calculate the dose rate in $\frac{\mathrm{krad}}{\min }$ from $\frac{\mu \mathrm{Ci}}{1}$ :

dose rate $\left(\frac{\mathrm{krad}}{\min }\right)=$ dose rate $\left(\frac{\mu \mathrm{Ci}}{1}\right) \times 10^{-6}\left(\frac{\mathrm{Ci}}{\mu \mathrm{Ci}}\right) \times 3.710^{10}\left(\frac{\text { disint. }}{\sec \times \mathrm{Ci}}\right) \times 60\left(\frac{\mathrm{sec}}{\mathrm{min}}\right) \times$

energy of particle $(\mathrm{eV}) \times 10^{-3}\left(\frac{1}{\mathrm{ml}}\right) \times 1.60 \times 10^{-14}\left(\frac{\mathrm{rad} \times \mathrm{gr}}{\mathrm{eV}}\right) \times 10^{-3}\left(\frac{\mathrm{krad}}{\mathrm{rad}}\right) /$ density $\left(\frac{\mathrm{gr}}{\mathrm{ml}}\right)$.

We assume the density is $1 \mathrm{gr} / \mathrm{ml}$ in the calculations.

b) The following energies of particles were used:

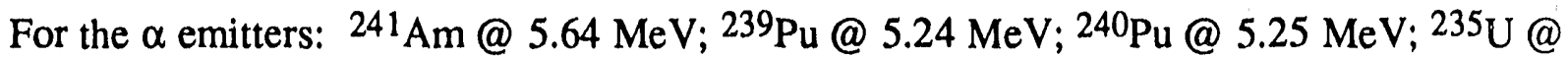
4.68 MeV; all taken from the CRC Handbook of Chemistry and Physics, 65th Edition, 1985.

For the $\beta$ emitters, the following energies were used: $90 \mathrm{Sr} @ 0.205 \mathrm{MeV} ;{ }^{90} \mathrm{Y} @ 0.93 \mathrm{MeV}$; ${ }^{99} \mathrm{Tc} @ 0.29 \mathrm{MeV}$. For the simultaneous $\beta$ and $\gamma$ emitter, ${ }^{137} \mathrm{Cs}$, average energies were used as follows: $\beta \mathrm{s} @ 1.18 \mathrm{MeV}$ (max.; $8 \%$ ) and $0.52 \mathrm{MeV}$ (max.; 92\%) to give an average of $0.24 \mathrm{MeV}$; $\gamma @ 0.66 \mathrm{MeV}(92 \%)$; combined average of $\beta \& \gamma=0.24+0.92 \times 0.66=0.85 \mathrm{MeV}$. Values for $\beta$ and $\gamma$ were taken from "Introduction to Radiation Chemistry" by J. W. T. Spinks and R. J. Woods, 3rd Edition, Wiley \& Sons (N.Y.), 1990. 
Table C-1. Conversion table for radiation sources in tank 101-SY (from $\frac{\mu \mathrm{Cia}}{1}$ to $\frac{\mathrm{krad}}{\mathrm{min}}$ ).

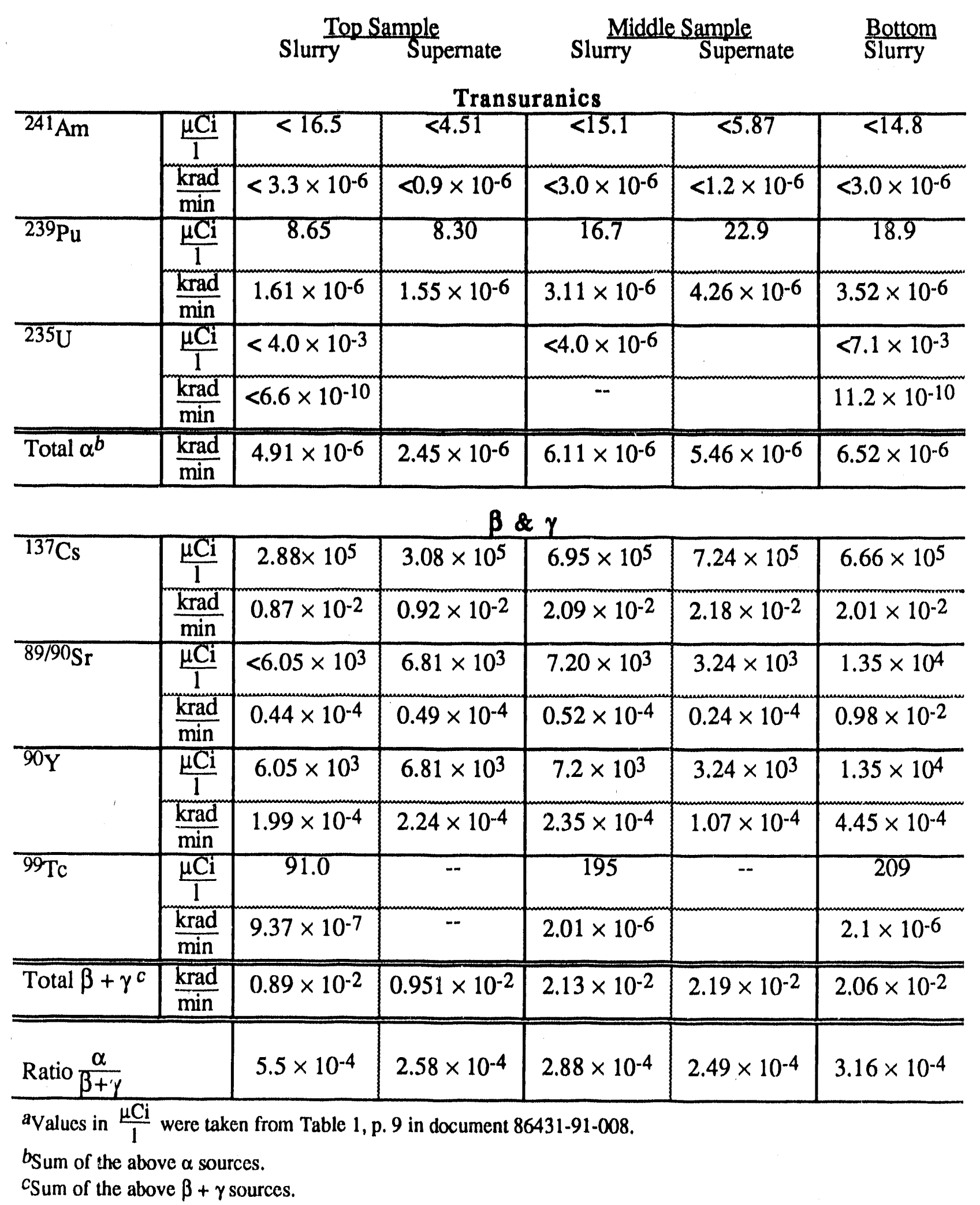




\section{REFERENCES}

(1) Meisel, D.; Diamond, H.; Horwitz, E. P.; Jonah, C. D.; Matheson, M. S.; Sauer, M. C. Jr.; Sullivan, J. C., "Radiation Chemistry of Synthetic Waste", ANL-91/40, November 1991.

(2) Reynolds, D. A.; Siemer, D. D.; Strachan, D. M.; Wallace, R. W., "A Survey of Available Information on Gas Generation in Tank 241-SY-101", PNL-7520, March 1991.

(3) Tank Waste Science Panel, "Chemical and Physical Processes in Tank 241-SY-101: A Preliminary Report", PNL-7595, February 1991.

(4) Allen, A. O. "The Radiation Chemistry of Water and Aqueous Solutions;" Van Nostrand Co.: Princeton, 1961.

(5) Herting, D. L., Letter dated May 1, 1991.

(6) Seimer, D. D., Private communication, 1991,

(7) Han, P.; Bartels, D. M., J. Phys. Chem. (1990), 94, 7294.

(8) Ashby, E. C., "Progress Report for 6 Month Period of April 15 - October 15, 1991; Mechanistic Elucidation of the Chemistry in Tank 101-SY", October 15, 1991.

(9) Meisel, D.; et al., Monthly report to G. D. Johnson - WHC, December 5, 1991.

(10) Campbell, J. A., Reported to the Science Panel meeting, Richland, WA, November 11-13, 1991.

(11) Bryan, S. A.; Pederson, L. R.; Scheele, R. D., Reported to the Science Panel Meeting, Atlanta, GA, July 9, 1991.

(12) Herting, D. L., Reported to the Science Panel Meeting, Atlanta, GA, July 9, 1991.

(13) Hart, E. J.; Thomas, J. K., "Application of the Van Slyke Manometric Apparatus to Radiation Chemistry", ANL 7856, 1971.

(14) Trumbore, C. N.; Short, D. R.; Fanning, J. E., Jr.; Olson, J. H., J. Phys. Chem. (1978), 82,2762 .

(15) Kuppermann, A., "Proceedings of the 3rd International Congress of Radiation Research"; G. Silini, Ed.; North Holland Publishing Co.: Amsterdam, 1967.

(16) Kuppermann, A., "Diffusion Kinetics in Radiation Chemistry: An Assessment"; U. S. Atomic Energy Commission: Report CALT-767P4-127, 1973.

(17) Jonah, C. D.; Matheson, M. S.; Miller, J. R.; Hart, E. J., J. Phys. Chem. (1976), 80, 1267.

(18) Schwarz, H. A., J. Phys. Chem. (1969), 73, 1928. 
Distribution for ANL-91/41

Internali:

F. Barnabas

D. Meisel (28)

F. A. Cafasso

E. Cerny

Y.-D. Cheng

H. Diamond

M. C. Sauer, Jr.

L. M. Stock

J. C. Sullivan

E. P. Horwitz

Y. Vojta

C. D. Jonah

ANL Patent Dept.

M. S. Matheson

ANL Contract File

TIS Files (3)

\section{External:}

DOE-OSTI for distribution per (UC-600) (13)

ANL Library

Manager, Chicago Operations Office, DOE

G. D. Johnson, Westinghouse Hanford Company (40) 

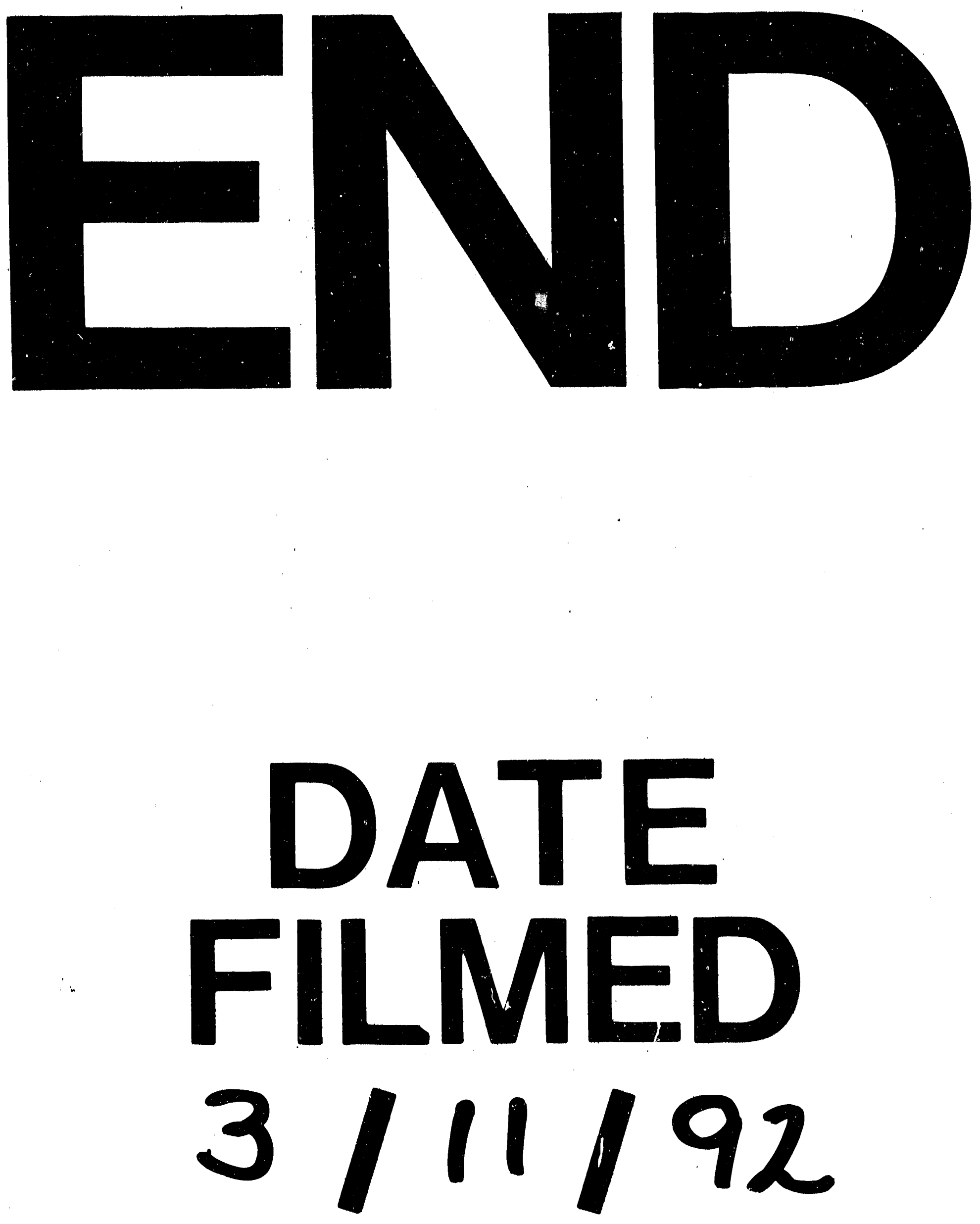
